University of Pennsylvania Carey Law School

Penn Law: Legal Scholarship Repository

Faculty Scholarship at Penn Law

$4-23-2013$

\title{
Innovation and Competition Policy, Ch. 2 (2d ed): Complementary Products and Processes - The Law of Tying
}

Herbert J. Hovenkamp

University of Pennsylvania Carey Law School

Follow this and additional works at: https://scholarship.law.upenn.edu/faculty_scholarship

Part of the Antitrust and Trade Regulation Commons, Courts Commons, Intellectual Property Law Commons, Law and Economics Commons, and the Technology and Innovation Commons

\section{Repository Citation}

Hovenkamp, Herbert J., "Innovation and Competition Policy, Ch. 2 (2d ed): Complementary Products and Processes - The Law of Tying" (2013). Faculty Scholarship at Penn Law. 1874.

https://scholarship.law.upenn.edu/faculty_scholarship/1874

This Article is brought to you for free and open access by Penn Law: Legal Scholarship Repository. It has been accepted for inclusion in Faculty Scholarship at Penn Law by an authorized administrator of Penn Law: Legal Scholarship Repository. For more information, please contact PennlawIR@law.upenn.edu. 


\section{INNOVATION AND COMPETITION POLICY, Ch. 2 (2d ed): COMPLEMENTARY PRODUCTS AND PROCESSES -- THE LAW OF TYING}

\section{Herbert Hovenkamp}

This book of CASES AND MATERIALS ON INNOVATION AND COMPETITION POLICY is intended for educational use. The book is free for all to use subject to an open source license agreement. It differs from IP/antitrust casebooks in that it considers numerous sources of competition policy in addition to antitrust, including those that emanate from the intellectual property laws themselves, and also related issues such as the relationship between market structure and innovation, the competitive consequences of regulatory rules governing technology competition such as net neutrality and interconnection, misuse, the first sale doctrine, and the Digital Millennium Copyright Act (DMCA). Chapters will be updated frequently. The author uses this casebook for a three-unit class in Innovation and Competition Policy taught at the University of Iowa College of Law and available to first year law students as an elective. The table of contents is as follows (click on chapter title to retrieve it):

Ch. 1: Competition Policy and the Scope of Intellectual Property Protection

Ch. 2 Complementary Products and Processes: The Law of Tying

Ch. 3 Harm to Competition or Innovation; Remedies

Ch. 4 Competition Policy and the Patent System

Ch. 5 Competition and Innovation in Copyright and the DMCA

Ch. 6 Restraints on Innovation

Ch. 7 Intellectual Property Misuse

Ch. 8 Innovation, Technology, and Anticompetitive Exclusion

Ch. 9 The Innovation Commons

Ch. 10; Post-Sale and Related Distribution Restraints Involving IP Rights

\section{$\underline{\text { Statutory Supplement and Other Materials }}$}

\section{(C) 2013. Herbert Hovenkamp}

License Agreement: The Author hereby grants You a royalty-free, nonexclusive, license to (a) reproduce this Original Work in copies for any purpose including classroom use; (b) prepare derivative works based upon the Original Work; and (c) distribute electronic or printed copies of the Original Work and Derivative Works to others; provided that, acknowledgement of the original author be made on all distributions of the original or derivative works; and distribution shall be noncommercial and without charge, except that reasonable costs of printing and distribution may be passed on. No copyright is claimed in unedited government or other public domain documents. 
INNOVATION AND COMPETITION POLICY

Hovenkamp

Chap. 2, Page 2

Jan., 2013

\section{INNOVATION AND COMPETITION POLICY \\ Cases and Materials \\ Herbert Hovenkamp}

CHAPTER 2 (2d ed)

\section{COMPLEMENTARY PRODUCTS AND PROCESSES: THE LAW OF TYING}

\section{HENRY V. A. B. DICK CO. 224 U.S. 1 (1912)}

Mr. Justice Lurton delivered the opinion of the court:

The facts and the questions certified, omitting the terms of the injunction awarded by the circuit court, are these:

"This action was brought by the complainant, an Illinois corporation, for the infringement of two letters patent, owned by the complainant, covering a stencil-duplicating machine known as the 'Rotary Mimeograph.' The defendants are doing business as copartners in the city of New York. The complainants sold to one Christina B. Skou, of New York, a Rotary Mimeograph embodying the invention described and claimed in said patents under license which was attached to said machine, as follows:

"This machine is sold by the A. B. Dick Company, with the license restriction that it may be used only with the stencil, paper, ink, and other supplies made by A. B. Dick Company.

"The defendant Sidney Henry sold to Miss Skou a can of ink suitable for use upon said mimeograph, with knowledge of the said license agreement, and with the expectation that it would be used in connection with said mimeograph. The ink sold to Miss Skou was not covered by the claims of said patent."

The meaning and purpose of this restriction was that while the property in the machine was to pass to the purchaser, the right to use the invention was restricted to use with other articles required in its practical operation, supplied by the patentee. It was stated at the bar, and appears fully in the opinion of Judge Ray (149 Fed. 424), who decided the case in the circuit court, that the patentee sold its machines at cost, or less, and depended upon 
INNOVATION AND COMPETITION POLICY

Hovenkamp
Chap. 2, Page 3

Jan, 2013

the profit realized from the sale of other nonpatented articles adapted to be used with the machine, and that it had put out many thousands of such machines under the same license restriction. Such a sale, while transferring the property right in the machine, carries with it only the right to use it for practising the invention according to the terms of the license. To no other or greater extent does the patentee consent to the use of the machine. When the purchaser is sued for infringement by using the device, he may defend by pleading, not the general and unlimited license which is carried by an unconditional sale, but the limited license indicated by the metal tablet annexed to the machine. If the use is not one permitted, it is plainly an infringing use.

If, then, we assume that the violation of restrictions upon the use of a machine made and sold by the patentee may be treated as infringement, we come to the question of the kind of limitation which may be lawfully imposed upon a purchaser.

To begin with, the purchaser must have notice that he buys with only a qualified right of use. He has a right to assume, in the absence of knowledge, that the seller passes an unconditional title to the machine, with no limitations upon the use. Where, then, is the line between a lawful and an unlawful qualification upon the use? This is a question of statutory construction. But with what eye shall we read a meaning into it? It is a statute creating and protecting a monopoly. It is a true monopoly, one having its origin in the ultimate authority, the Constitution. Shall we deal with the statute creating and guaranteeing the exclusive right which is granted to the inventor with the narrow scrutiny proper when a statutory right is asserted to uphold a claim which is lacking in those moral elements which appeal to the normal man? Or shall we approach it as a monopoly granted to subserve a broad public policy, by which large ends are to be attained, and therefore to be construed so as to give effect to a wise and beneficial purpose? That we must neither transcend the statute, nor cut down its clear meaning, is plain. In E. Bement \& Sons v. National Harrow Co. 186 U. S. 70, 89-92, this court quoted with approval the language of Chief Justice Marshall in Grant v. Raymond, 6 Pet. 218, 241. Concerning the favorable view which the law takes as to the protection extended to the exclusive right, the court, through Chief Justice Marshall, said:

"It is the reward stipulated for the advantages derived by the public for the exertions of the individual, and is intended as a stimulus to those exertions. The laws which are passed to give effect to this purpose 
INNOVATION AND COMPETITION POLICY

Hovenkamp
Chap. 2, Page 4

Jan., 2013

ought, we think, to be construed in the spirit in which they have been made; and to execute the contract fairly on the part of the United States, where the full benefit has been actually received, if this can be done without transcending the intention of the statute, or countenancing acts which are fraudulent or may prove mischievous. The public yields nothing which it has not agreed to yield, it receives all which it has contracted to receive. The full benefit of the discovery, after its enjoyment by the discoverer for fourteen years, is preserved; and for his exclusive enjoyment of it during that time the public faith is pledged."

If the patent be for a machine, the monopoly extends to the right of making, selling, and using, and these are separable and substantial rights. In Bloomer v. McQuewan, 14 How. 539, 547, it is said that the grant is of "the right to exclude everyone from making, using, or vending the thing without the permission of the owner." In E. Bement \& Sons v. National Harrow Co. 186 U. S. 70, 90, there was involved the legality of certain contracts between patentees of and dealers in patented harrows. The purpose and effect of the combination and of the contracts between the parties was to fix and keep up the prices at which licensees might sell the patented harrows. It was claimed that the combination and contracts were obnoxious to the Sherman act; but, upon the other side, it was said that as the contracts concerned only the sale of patented articles, that that act did not apply. The character of the monopoly granted under the patent act was therefore involved....

Now, if this was a suit to recover damages upon the contract not to use the machine except in connection with other articles proper in its use, made by the patentee, the only possible defense would be that the agreement was one contrary to public policy, in that it affected freedom in the sale of such articles to the user of such machines. But that was the nature of the defense made to the suit to enforce the agreements under consideration in the Bement Case. The court in that case found that the contracts did include interstate commerce within their provisions and restrained interstate trade, but with reference to the Sherman act:

"But that statute clearly does not refer to that kind of a restraint of interstate commerce which may arise from reasonable and legal conditions imposed upon the assignee or licensee of a patent by the owner thereof, restricting the terms upon which the article may be used and the price to be demanded therefor. Such a construction of the act, we have no doubt, was 
INNOVATION AND COMPETITION POLICY

Hovenkamp
Chap. 2, Page 5

Jan, 2013

never contemplated by its framers."

As to whether the restrictions upon sales imposed by the agreements were "legal and reasonable conditions," the court said:

"The provision in regard to the price at which the licensor would sell the article manufactured under the license was also an appropriate and reasonable condition. It tended to keep up the price of the implements manufactured and sold, but that was only recognizing the nature of the property dealt in, and providing for its value so far as possible. This the parties were legally entitled to do. The owner of a patented article can, of course, charge such price as he may choose, and the owner of a patent may assign it or sell the right to manufacture and sell the article patented upon the condition that the assignee shall charge a certain amount for such article."

If the stipulation in an agreement between patentees and dealers in patented articles, which, among other things, fixed a price below which the patented articles should not be sold, would be a reasonable and valid condition, it must follow that any other reasonable stipulation, not inherently violative of some substantive law, imposed by a patentee as part of a sale of a patented machine, would be equally valid and enforceable. It must also follow that if the stipulation be one which qualifies the right of use in a machine sold subject thereto, so that a breach would give rise to a right of action upon the contract, it would be at the same time an act of infringement, giving to the patentee his choice of remedies.

But it has been very earnestly said that a condition restricting the buyer to use it only in connection with ink made by the patentee is one of a character which gives to a patentee the power to extend his monopoly so as to cause it to embrace any subject, not within the patent, which he chooses to require that the invention shall be used in connection with. Of course, the argument does not mean that the effect of such a condition is to cause things to become patented which were not so without the requirement. The stencil, the paper, and the ink made by the patentee, will continue to be unpatented. Anyone will be as free to make, sell, and use like articles as they would be without this restriction, save in one particular, - namely, they may not be sold to a user of one of the patentee's machines with intent that they shall be used in violation of the license. To that extent competition in the sale of such articles, for use with the machine, will be affected; for sale to such users for infringing purposes will constitute contributory infringement. But 
INNOVATION AND COMPETITION POLICY

Hovenkamp
Chap. 2, Page 6

Jan., 2013

the same consequence results from the sale of any article to one who proposes to associate it with other articles to infringe a patent, when such purpose is known to the seller. But could it be said that the doctrine of contributory infringement operates to extend the monopoly of the patent over subjects not within it because one subjects himself to the penalties of the law when he sells unpatented things for an infringing use? If a patentee says, "I may suppress my patent if I will. I may make and have made devices under my patent, but I will neither sell nor permit anyone to use the patented things," he is within his right, and none can complain. But if he says, "I will sell with the right to use only with other things proper for using with the machines, and I will sell at the actual cost of the machines to me, provided you will agree to use only such articles as are made by me in connection therewith,"-if he chooses to take his profit in this way, instead of taking it by a higher price for the machines, has he exceeded his exclusive right to make, sell, and use his patented machines? The market for the sale of such articles to the users of his machine, which, by such a condition, he takes to himself, was a market which he alone created by the making and selling of a new invention. Had he kept his invention to himself, no ink could have been sold by others for use upon machines embodying that invention. By selling it subject to the restriction, he took nothing from others and in no wise restricted their legitimate market.

For the purpose of testing the consequence of a ruling which will support the lawfulness of a sale of a patented machine for use only its connection with supplies necessary for its operation, bought from the patentee, many fanciful suggestions of conditions which might be imposed by a patentee have been pressed upon us. Thus it is said that a patentee of a coffee pot might sell on condition that it be used only with coffee bought from him, or, if the article be a circular saw, that it might be sold on condition that it be used only in sawing logs procured from him. These and other illustrations are used to indicate that this method of marketing a patented article may be carried to such an extent as to inconvenience the public and involve innocent people in unwitting infringements. But these illustrations all fail of their purpose, because the public is always free to take or refuse the patented article on the terms imposed. If they be too onerous or not in keeping with the benefits, the patented article will not find a market. The public, by permitting the invention to go unused, loses nothing which it had before, and when the patent expires will be free to use the invention without compensation or restriction. This was pointed out in the Paper Bag Case, where the inventor would neither use himself nor allow others to use, and yet was held entitled to restrain infringement, because he 
INNOVATION AND COMPETITION POLICY

Hovenkamp
Chap. 2, Page 7

Jan, 2013

had the exclusive right to keep all others from using during the life of the patent. This larger right embraces the lesser of permitting others to use upon such terms as the patentee chooses to prescribe. It must not be forgotton [sic] that we are dealing with a constitutional and statutory monopoly. An attack upon the rights under a patent because it secures a monopoly to make, to sell, and to use, is an attack upon the whole patent system. We are not at liberty to say that the Constitution has unwisely provided for granting a monopolistic right to inventors, or that Congress has unwisely failed to impose limitations upon the inventor's exclusive right of use. And if it be that the ingenuity of patentees in devising ways in which to reap the benefit of their discoveries requires to be restrained, Congress alone has the power to determine what restraints shall be imposed. As the law now stands it contains none, and the duty which rests upon this and upon every other court is to expound the law as it is written. Arguments based upon suggestions of Public policy not recognized in the patent laws are not relevant. The field to which we are invited by such arguments is legislative, not judicial. The decisions of this court, as we have construed them, do not so limit the privilege of the patentee, and we could not so restrict a patent grant without overruling the long line of judicial decisions from circuit courts and circuit courts of appeal, heretofore cited, thus inflicting disastrous results upon individuals who have made large investments in reliance upon them.

The conclusion we reach is that there is no difference, in principle, between a sale subject to specific restrictions as to the time, place, or purpose of use, and restrictions requiring a use only with other things necessary to the use of the patented article purchased from the patentee. If the violation of the one kind is an infringement, the other is also. That a violation of any such restriction annexed to a sale by one with notice constitutes an infringing use has been decided by a great majority of the circuit courts and circuit courts of appeal, and has come to be a wellrecognized principle in the patent law, in accordance with which vast transactions in respect to patented articles have been conducted. But it is now said that the numerous decisions by the lower courts have been erroneous in respect to the proper construction of the limit of the monopoly conferred by a patent, and that they should now be overruled. To these courts has been committed the duty of interpreting and administering the patent law. There is no power in this court to review their judgments, except upon a writ of certiorari, or to direct their decisions, save through a certified interrogatory for direction upon a question of law. This power to review by certiorari is one which has been seldom exercised in patent cases. A line of 
INNOVATION AND COMPETITION POLICY

Hovenkamp
Chap. 2, Page 8

Jan., 2013

decisions which has come to be something like a rule of property, under which large businesses have been conducted, should at least not be overruled except upon reasons so clear as to make any other construction of the patent law inadmissible....

Mr. Chief Justice White, with whom concurred Mr. Justice Hughes and Mr. Justice Lamar, dissenting:

... [T]he ink was not covered by the patent; indeed, it is stated in argument, and not denied, that a prior patent which covered the ink had expired before the sale in question. It therefore results that a claim for the ink could not have been lawfully embraced in the patent, and if it had been by inadvertence allowed, such claim would not have been enforceable. This curious anomaly, then, results, that that which was not embraced by the patent, which could not have been embraced therein, and which, if mistakenly allowed and included in an express claim, would have been inefficacious, is now, by the effect of a contract, held to be embraced by the patent and covered by the patent law....

The exclusive right of use of the invention embodied in the machine which the patent protected was a right to use it anywhere and everywhere, for all and every purpose of which the machine, as embraced by the patent, was susceptible. The patent was solely upon the mechanism which, when operated, was capable of producing certain results. A patent for this mechanism was not concerned in any way with the materials to be used in operating the machine, and certainly the right protected by the patent was not a right to use the mechanism with any particular ink or other operative materials. Of course, as the owner of the machine possessed the ordinary right of an owner of property to use such materials as he pleased in operating his patented machine, and had the power in selling his machine to impose such conditions in the nature of covenants not contrary to public policy as he saw fit, I shall assume that he had the power to exact that the purchaser should use only a particular character of materials. But as the right to employ any desired operative materials in using the patented machine was not a right derived from or protected by the patent law, but was a mere right arising from the ownership of property, it cannot be said that the restriction concerning the use of the materials was a restriction upon the use of the machine protected by the patent law. When I say it cannot be said, I mean that it cannot be so done in reason, since the inevitable result of so doing would be to declare that the patent protected a use which it did not embrace. And this, after all, serves to demonstrate that it is a misconception 
INNOVATION AND COMPETITION POLICY

Hovenkamp
Chap. 2, Page 9

Jan, 2013

to qualify the restriction as one on the use of the machine, when in truth, both in form and substance, it was but a restriction upon the use of materials capable of being employed in operating the machine. In other words, every use which the patent protected was transferred to Miss Skou, and the very existence of the particular restriction under consideration presupposes such right of complete enjoyment, and because of its possession there was engrafted a contract restriction, not upon the use of the machine, but upon the materials. And these considerations are equally applicable to the exercise of the exclusive right to vend protected by the patent unless it can be said that, by the act of selling a patented machine, and disposing of all the use of which it is capable, a patentee is endowed with the power to amplify his patent by causing it to cover in the future things which, at the time of the sale, it did not embrace.

But the result of this analysis serves at once again to establish, from another point of view, that the ruling now made in effect is that the patentee has the power, by contract, to extend his patent rights so as to bring within the claims of his patent things which are not embraced therein, thus virtually legislating by causing the patent laws to cover subjects to which, without the exercise of the right of contract, they could not reach, the result not only to multiply monopolies at the will of an interested party, but also to destroy the jurisdiction of the state courts over subjects which, from the beginning, have been within their authority....

Again, a curious anomaly would result from the doctrine. The law, in allowing the grant of a patent to the inventor, does not fail to protect the rights of society; on the contrary, it safeguards them. The power to issue a patent is made to depend upon considerations of the novelty and utility of the invention. and the presence of these prerequisites must be ascertained and sanctioned by public authority; and although this authority has been favorably exerted, yet, when the rights of individuals are concerned, the judicial power is then open to be invoked to determine whether the fundamental conditions essential to the issue of the patent existed. Under the view now maintained of the right of a patentee by contract to extend the scope of the claims of this patent, it would follow that the incidental right would become greater than the principal one, since by the mere will of the party rights by contract could be created, protected by the patent law, without any of the precautions for the benefit of the public which limit the right to obtain a patent.....

For these reasons I therefore dissent. 
INNOVATION AND COMPETITION POLICY

Hovenkamp
Chap. 2, Page 10

Jan., 2013

\section{NOTES AND QUESTIONS}

1. In Heaton-Peninsular Button-Fastener Co. v. Eureka Specialty Co., 77 F. 288 (6th Cir. 1896), the Sixth Circuit Court of Appeals refused to condemn a similar variable proportion tying arrangement involving a machine that fastened buttons to garments and the "staples" that were used to do the fastening. Judge Lurton - at the time still on the Sixth Circuit bench, with later to be Chief Justice Taft sitting on the panel — wrote for the court:

What we are asked to do is to mark a ... boundary line around the patentee's monopoly, which will debar him from engrossing the market for an article not the subject of a patent. To do this, we are asked to say that he cannot license others to use his invention on condition that they shall use it only in conjunction with a nonpatentable article made by himself. The only reason suggested for this limitation upon his right to define the terms upon which others may use his invention is that a monopoly in the unpatented article may thereby be created. Upon what authority are we to circumscribe the exercise of the privileges awarded a patentee? In considering any question in respect of restraints upon the liberty of contracting, imposed by principles of public policy, we should bear in mind that very high considerations of public policy are involved in the recognition of a wide liberty in the making of contracts. This caution was well expressed by Sir George Jessell in Registering Co. v. Sampson, L.R. 19 Eq. 462-465, who said: "It must not be forgotten that you are not to extend arbitrarily those rules which say that a given contract is against public policy, because, if there is one thing which, more than another, public policy requires, it is that men of full age and competent understanding shall have the utmost liberty of contracting, and that their contracts, when entered into freely and voluntarily, shall be held sacred, and shall be enforced by courts of justice. Therefore you have this paramount public policy to consider, - that you are not lightly to interfere with this freedom of contract."

... If the patentee choose to reserve to himself the exclusive use of his device, and the invention be of a wide 
character, and so radical as to enable him to make and sell an unpatentable product cheaper than any other competitor, a practical monopoly of the market for that article will result; and yet no one could say that a monopoly thus secured was illegitimate, or obnoxious to public policy. To illustrate: Let it be supposed that the patents owned by this complainant were of so wide a character as to cheapen the process of manufacturing shoes, and to drive from competition all other modes of manufacture. Then suppose the patentees were of opinion that they could most profitably enjoy their inventions by retaining the monopoly of the use, and engaging in the manufacture of shoes. If content to undersell all others, they could engross the market for shoes, to the extent of their capacity to supply the demand during the life of their patents, or so long as their invention was not superseded by subsequent inventions still further cheapening the cost of manufacture. The monopoly thus secured would be the legitimate consequence of the meritorious character of their invention. Yet just such monopolies may result whenever a new and surprising advance is made in some art of wide and general use. The great consuming public would be benefited, rather than injured, for the monopoly could endure so long only as shoes were supplied at a less price than had prevailed before the invention. Now, if the patentees, by retaining to themselves the exclusive use of their invention, are able, legitimately and lawfully, to acquire a monopoly of the manufacture of shoes, and destroy the shoe market for those who before had shared it, why may they not, by a system of restricted licenses, permit others to use their devices on condition that only some minor part of the shoe,- - the pegs, the tips, the thread, or the buttons, or the button fasteners, - shall be bought from them? If these concessions were such as to enable others to compete, though their use of the mechanism was restricted by the terms of the license, who could justly complain if the inventors, content with a monopoly of the market for the article named in their license, surrendered the opportunity for a monopoly of the manufacture of the complete shoe? The device protected by the patents owned by complainant is of no such wide or radical character as that used for purposes of illustration. Yet there is no appreciable difference in the legal 
principles applicable to the supposed facts used for illustration, and those stated on the face of the complainant's bill. The fact which has affected the makers of wire staples for shoe manufacturing is the invention of a machine which, by its simplicity, superior capabilities, its cheapness and accuracy, has practically driven all other methods of fastening buttons to shoes out of use. The older and clumsier methods, on the allegations of the bill, have been completely superseded. From this invention there results a large market for wire staples, adapted in size and shape to use with the new mechanism, and a second consequence is the complete cessation of the demand for button fasteners not adapted to be used with complainant's machine. To supply staples adapted to meet this new demand becomes a matter of moment to those engaged in the business of making wire button fasteners. The inventions covered by complainant's patents are not of such character as to enable them, by retaining the exclusive use, to absorb either the making of shoes, or the minor work of fastening buttons to shoes. In the exercise of the right of exclusive use, they have put on the market a structure embodying their devices, and licensed the purchaser to use the invention "only with staples" made by themselves. In other words, they have chosen to fix the price for the right of use at the profit resulting from the sale of staples. As observed by counsel for complainant, "The fasteners are thus made the counters by which the royalty proportioned to the actual use of the machine is determined." This method of licensing their mechanism may or may not result in the engrossment of the market for staples. So long as their invention controls the market for button-fastening appliances, and to the extent that their machines shall supersede other modes of clinching staples, just so long will they be enabled to control the market for staples. Their monopoly in an unpatented article will depend upon the merit of their patented device, and the extent to which other clinching devices are superseded by it. In the last analysis, the invention destroyed the demand for sizes and shapes of staples not adapted to use with the machine of complainant, and the monopoly of the use awarded by the patents destroyed the market for staples fitted for use in complainant's machines. The monopoly in the unpatented 
staple results as an incident from the monopoly in the use of complainant's invention, and is therefore a legitimate result of the patentee's control over the use of his invention by others. Depending, as such a monopoly would, upon the merits of the invention to which it is a mere incident, it is neither obnoxious to public policy, nor an illegal restraint of trade.

The Sixth Circuit also rejected the argument that a breach of contract suit for damages would be an adequate remedy:

The bill discloses that more than 49,000 machines are in use, and charges a long-continued infringement, and a purpose to continue therein. Under the circumstances, it must be evident that, both upon the ground of avoiding a multiplicity of lawsuits, and upon the general and apparent inadequacy of a suit at law for damages, either against the infringer who infringes by an unauthorized use, or those who actively contribute to that infringement, a court of equity has jurisdiction. An action at law for the character of continuing trespass alleged by complainant would be grossly inadequate to protect the patents from invasion. If the complainant has the right to reserve a control over the us'e in the manner stated in its bill, then its machines, to the extent it has reserved such control, are within the monopoly of the patents. If its licenses do not infringe public policy, but are within the privileges awarded by the patents, then it must follow that the case presented should be accorded relief by injunction restraining the acts complained of. A court of equity has the power, independently of any other relief, to restrain the continuing infringement of a patent.

For further discussion of the problem of breach of contract suits vs. infringement suits in order to enforce aftermarket restraints such as ties, see Chapter ten; and CHRISTINA BOHANNAN \& HERBERT HOVENKAMP, CREATION Without RESTRAINT: PROMOTING LiBERTY AND RIVALRY IN INNOVATION, Ch. 13 (2011).

2. The court emphasizes that a precondition to contributory infringement or infringement for failure to follow the tying condition is that the buyer have actual knowledge of the restriction. 
This is an important difference between contributory infringement and patent infringement generally, which does not require that the infringer have notice of the patent being infringed.

\section{NOTE: VARIABLE PROPORTION TIES: PRICE DISCRIMINATION AND WELFARE EFFECTS}

Sellers often use variable proportion ties such as the one in Henry in order to engage in a kind of price discrimination. ${ }^{1}$ Such ties benefit some customers but injure others; on balance they are probably beneficial in most cases. As a result there is no warrant for condemning them categorically under the antitrust laws. But price discrimination is not easy. To do it profitably sellers must (1) have some control over price-i.e., some market power; (2) separate consumers into discrete groups with different reservation prices; and (3) prevent arbitrage-low-price consumers reselling to high-price consumers.

In the standard economic analysis, there are three kinds of price discrimination. ARThur Cecil Pigou, The Economics of Welfare $\S$ II.17.5 (4th ed. 1932). First-degree, or 'perfect,' price discrimination involves selling each unit of a good at the highest price any consumer is willing to pay for that unit. Perfect price discrimination leaves no consumer surplus and instead gives all gains to the sellers. Sellers would love to do this, but first-degree price discrimination is virtually impossible because there is no practical way for a seller to discover the highest price each consumer will pay for its goods or services.

By contrast, second- and third-degree price discrimination are common. In third-degree price discrimination, a seller divides its customers into discrete groups based on observations about their willingness to pay and charges each group a unique price. For example, A. B. Dick could divide its customers into students and nonstudents and sell its mimeographs to students for $\$ 80$ and nonstudents for $\$ 100$. This pricing scheme would allow A. B. Dick to sell mimeographs to students who would not buy if the company had to charge all consumers the same monopoly price, which would probably fall somewhere between $\$ 80$ and $\$ 100$. On the other hand,

${ }^{1}$ See Herbert Hovenkamp \& Erik Hovenkamp, Tying Arrangements and Antitrust Harm, 52 ARIZ.L.REV. 925, 943-950 (2010). For a contrary argument, to the effect that variable proportion ties may discourage innovation in the tied market, see Christopher R. Leslie, Patent Tying, Price Discrimination, and Innovation, 77 Antitrust L.J. 811 (2011). 
INNOVATION AND COMPETITION POLICY

Hovenkamp
Chap. 2, Page 15

Jan, 2013

the scheme excludes nonstudents who would pay more than $\$ 80$ but less than $\$ 100$ - even nonstudents who would pay more than the nondiscriminatory monopoly price. As a result, third-degree price discrimination tends to take some goods out of the hands of consumers who value them more and puts them into the hands of consumers who value them less.

In second-degree price discrimination, sellers offer all consumers the same price schedule, with different unit prices corresponding to different quantities or product varieties. Consumers then segregate themselves by selecting the price and quantity/variety they prefer. A. B. Dick's mimeograph tie-in is a classic example of second-degree price discrimination known as a variable-proportion tie, in which different consumers use different amounts of the tied product. ${ }^{2}$ In another case the defendant sold its patented refrigeration box on the condition that customers use only the seller's dry ice. ${ }^{3}$ These firms are engaging in a type of second degree price discrimination by dropping the price of the primary, or tying, good, and increasing the price of a tied good. ${ }^{4}$ The firm then earns a higher return from those who purchase a great deal of the tied good than from those who purchase smaller amounts. Such tying arrangements have produced voluminous private antitrust litigation. ${ }^{5}$ These cases are also ubiquitous in the franchise industry, where variable proportion tying is a common mechanism for reducing franchisee entry costs and enlarging franchisor profits through price discrimination. The price of the franchise (the tying product) is often zero, but is in any event much lower than the standalone value of the franchise. For example, a nondominant franchisor

${ }^{2}$ See 9 Phillip E. Areeda \& Herbert Hovenkamp, Antitrust Law I1711 (3d ed. 2011).

${ }^{3}$ Henry v. A.B. Dick \& Co., 224 U.S. 1 (1912); Carbice Corp. v. Am. Patents Dev. Corp., 283 U.S. 27 (1931) (same, tying patented refrigeration box and dry ice).

${ }^{4}$ E.g. Xerox Corp. v. Media Sciences, Inc., 660 F. Supp. 2d 535, 539 (S.D.N.Y. 2009) (printer/ink tie - "As is true of other printer manufacturers, Xerox generally sells its printers at a low margin or a loss, hoping to earn a profit through later sales of high margin ink").

5 See Static Control Components, Inc. v. Lexmark Intern., Inc., 487 F.Supp.2d 861 (E.D.Ky. 2007) (denying summary judgment on claim of tying printers and print cartridges via technological tie); In re Apple iPod/iTunes Anttrust Litigation, 2010 WL 2629907 (N.D.Cal. June 29, 2010) (denying summary judgment on claim that Apple unlawfully tied its iTunes media library to various Apple devices). 
may give franchises to firms at no charge but then tie food products or other consumables and place an overcharge on these. ${ }^{6}$ Once again, the franchisor earns more from higher volume franchises.

\section{Figure One}

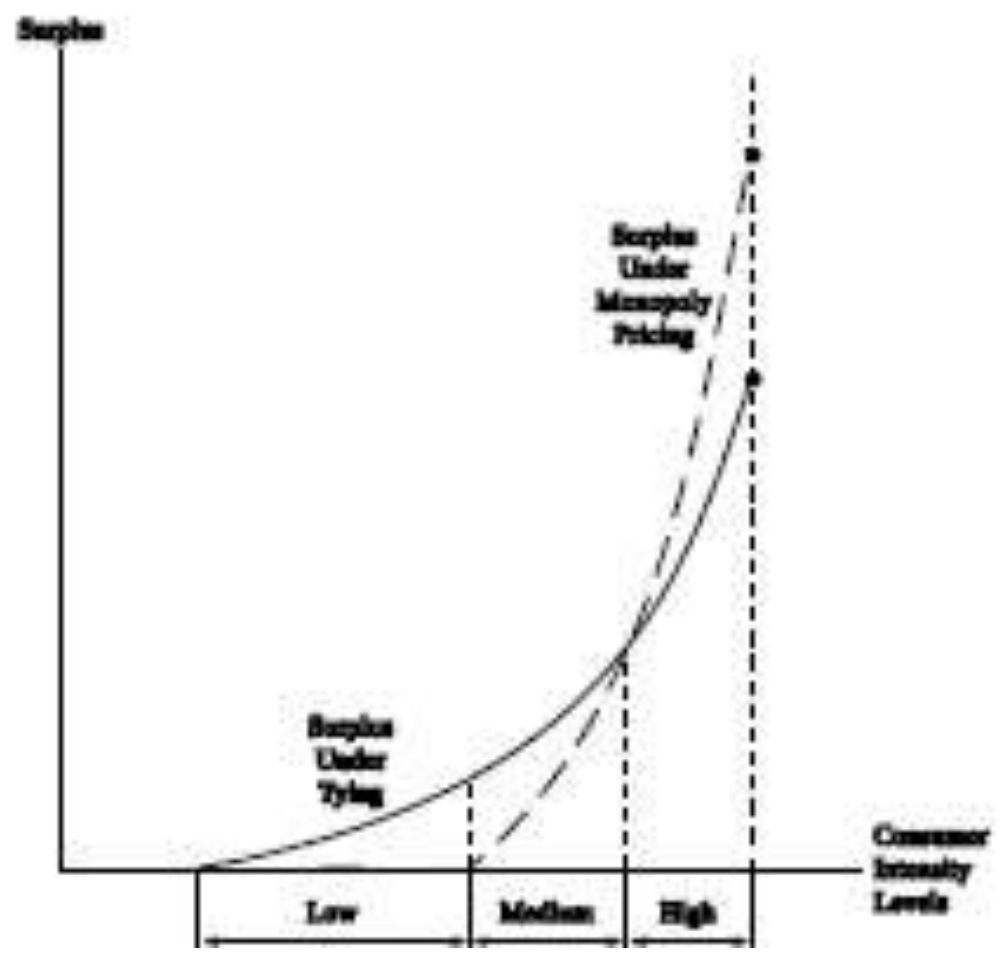

Figure one illustrates the complex consumer impact of variable proportion ties. The vertical axis measures consumers' surplus, while the horizontal axis measures the number of tied units that the consumer purchases. The solid line gives consumers' surplus under tying and the dotted line without tying. Consumers are divided into three categories arrayed along the horizontal axis. ${ }^{7}$ The low preference category consists of

${ }^{6}$ E.g., Siegel v. Chicken Delight, 448 F.2d 43, 46-47 (9th Cir. 1971), cert. denied, 405 U.S. 955 (1972) (franchise fee of zero, tying consumable products at overcharge).

${ }^{7}$ They are actually divided into four categories. At the extreme left next to the origin the unnamed space consists of consumers who do not even purchase the tying product at the reduced price under the tying arrangement. 
INNOVATION AND COMPETITION POLICY

Hovenkamp
Chap. 2, Page 17

Jan, 2013

consumers who would not be in the market at all at standalone pricing, but who enter the market in response to the tying product price cut. For example, a firm selling computer printers at a standalone price of $\$ 400$ might cut the price to $\$ 200$, but then charge $\$ 20$ for an ink cartridge that would otherwise sell for $\$ 10$. For these low preference consumers the tie is an unqualified welfare gain, because they would not be in the market at all under single product pricing. The magnitude of their gains depends on the size of the printer output increase in response to the price cut, and this can be very large when the demand curve is convex to the origin and is fairly shallow in the higher output reaches.

The middle group of customers consists of those who would have been in the market under standalone pricing, but for them the price decrease in the printer is greater than the price increase in the cartridges. For example, if someone in our illustration used fewer than 20 printer cartridges over the printer's lifetime he or she would come out ahead under tying. ${ }^{8}$ The size of this group depends on a number of factors. One factor is the durability of the tying product and the amount of tied product used during its lifetime. Another is whether the tie is air tight. For example, many printer manufacturers attempt to tie cartridges but their success is limited to the extent that customers or third parties can refill cartridges or produce generics. ${ }^{9}$ A third factor is the depth of the tying product price cut and the height of the tied product price increase.

The third group of "high" intensity buyers are made worse off by the tie. They are the ones that use more than twenty cartridges in our illustration. As a result the higher cartridge prices more than offset the

Since they are out of the market under both tying and independent sales, they are indifferent to the tie.

8 A user of nineteen cartridges over the lifetime of the printer would spend $\$ 190$ additional on cartridges but would have saved $\$ 200$ on the printer itself.

${ }^{9}$ This is a principal issue in the ongoing Lexmark litigation, cited above, in which Lexmark attempted to use a microprocessor that required the printer to be able to "read" a particular cartridge before it would work, but third parties were able to emulate the microprocessor. See Lexmark Intern., Inc. v. Static Control Components, Inc., 387 F.3d 522 (6 ${ }^{\text {th }}$ Cir. 2004) (third party's evasion of microprocessor lock very likely did not violate the Digital Millennium Copyright Act, which can bar the circumvention of technological locks on copyrighted material). 
INNOVATION AND COMPETITION POLICY

Hovenkamp

lower printer price.
Chap. 2, Page 18

Jan., 2013

Whether consumers in the aggregate are better or worse off would be extraordinarily difficult to assess. Further, two additional elements of consumer benefit may need to be considered. First, for a manufactured good such as a printer there are likely to be economies of scale in production that enable the manufacturer to achieve lower costs at higher volume. Conceivably even the high preference users could be better off if the tie plus printer price cut brings enough new customers into the market.

Second, if both the tying and tied good are sold in markets that are not strongly competitive the tie is likely to eliminate a certain amount of double marginalization, which occurs when two sellers supply vertically related or complementary goods that are consumed together and each of them has some market power. ${ }^{10}$ If the firms are unable to coordinate their output by selling it together, then each will charge a higher price than a single firm would charge if it sold both goods together. The elimination of double marginalization by tying will benefit all consumers if the two goods are perfect complements -- that is, if each of them has no value without the other. If they are only imperfect complements, however, then the story is more complex. For those customers who want both the tying and tied good, the tie should result in a price reduction and a consumer benefit. However, customers that do not want the tied good at all will be worse off because any positive price whatsoever for the tied good injures them. For that reason a bundled discount may be preferable for tying of imperfect complements. For example, suppose A \& B are imperfect complements. $80 \%$ of customers want both, but $20 \%$ want only A. The separate prices for $\mathrm{A}$ and $\mathrm{B}$ are $\$ 10$ and $\$ 5$, but by eliminating double marginalization a seller can earn more by selling the combination for, say, $\$ 12$. In that case it can offer the combination to customers who want it, thus benefitting them and increasing its own profits. But it can also continue selling good A for the original price of $\$ 10$. In this way a bundled discount can benefit the seller

${ }^{10}$ On double marginalization in tying, see CHRISTINA BOHANNAN \& Herbert Hovenkamp, Creation Without Restraint: Promoting LIBERTY AND RIVALRY IN INNOVATION, ch. 2 (2011); Hovenkamp \& Hovenkamp, Tying Arrangements and Antitrust Harm, 52 ARIZ.L.REV. at 958-961. In the case of complementary products the theory of double marginalization is sometimes referred to as "Cournot Complements," because Cournot applied his theory of oligopoly pricing to producers of complements as well as competitors. 
by permitting it to earn more on the tied combination, and also benefit the buyers who want both goods by giving them a lower price. The buyers who want only good A are neither better nor worse off. See Erik Hovenkamp \& Herbert Hovenkamp, Tying Arrangements, OXFORD INTERNATIONAL HANDBOOK OF COMPETITION POLICY (2012).

\section{MOTION PICTURE PATENTS CO. V. UNIVERSAL FILM MANUFACTURING CO. 243 U.S. 502 (1917)}

Mr. Justice Clarke delivered the opinion of the court:

... Evidence which is undisputed shows that the plaintiff, on June 20, 1912, in a paper styled "License Agreement," granted to the Precision Machine Company a right and license to manufacture and sell machines embodying the inventions described and claimed in the patent in suit.... This agreement contains a covenant ... that to each machine sold [the grantee] will attach a plate showing plainly not only the dates of the letters patent under which the machine is "licensed," but also the following words and figures:

"The sale and purchase of this machine gives only the right to use it solely with moving pictures containing the invention of reissued patent No. 12,192, leased by a licensee of the Motion Picture Patents Company, the owner of the above patents and reissued patent, while it owns said patents, and upon other terms to be fixed by the Motion Picture Patents Company and complied with by the user while it is in use and while the Motion Picture Patents Company owns said patents. The removal or defacement of this plate terminates the right to use this machine."

. . . On January 18,1915 ... the plaintiff addressed a letter to the defendant Universal Film Exchange, notifying it that it ... was infringing the same patents by supplying films for use upon the machine of the Seventy-second street playhouse and elsewhere....

It was admitted at the bar that 40,000 of the plaintiff's machines are now in use in this country, and that the mechanism covered by the patent in suit is the only one with which motion picture films can be used successfully. 
.... It is obvious that in this case we have presented anew the inquiry, which is arising with increasing frequency in recent years, as to the extent to which a patentee or his assignee is authorized by our patent laws to prescribe by notice attached to a patented machine the conditions of its use and the supplies which must be used in the operation of it, under pain of infringement of the patent.

The statutes relating to patents do not provide for any such notice and it can derive no aid from them.....

The extent to which the use of the patented machine may validly be restricted to specific supplies or otherwise by special contract between the owner of a patent and the purchaser or licensee is a question outside the patent law, and with it we are not here concerned.

The inquiry presented by this record, as we have stated it, is important and fundamental, and it requires that we shall determine the meaning of Congress when, in Rev. Stat. § 4884, Comp. Stat. 1913, § 9428, it provided that "every patent shall contain ... a grant to the patentee, his heirs or assigns, for the term of seventeen years, of the exclusive right to make, use, and vend the invention or discovery throughout the United States, and the territories thereof." We are concerned only with the right to "use," authorized to be granted by this statute, for it is under warrant of this right only that the plaintiff can and does claim validity for its warning notice....

In interpreting this language of the statute it will be of service to keep in mind three rules long established by this court, applicable to the patent law and to the construction of patents, viz.:

1st. The scope of every patent is limited to the invention described in the claims contained in it, read in the light of the specification. These so mark where the progress claimed by the patent begins and where it ends that they have been aptly likened to the description in a deed, which sets the bounds to the grant which it contains. It is to the claims of every patent, therefore, that we must turn when we are seeking to determine what the invention is, the exclusive use of which is given to the inventor by the grant provided for by the statute,-- "He can claim nothing beyond them."

$2 \mathrm{~d}$. It has long been settled that the patentee receives nothing from the law which he did not have before, and that the only effect of his patent is to 
restrain others from manufacturing, using, or selling that which he has invented. The patent law simply protects him in the monopoly of that which he has invented and has described in the claims of his patent.

3d. Since Pennock v. Dialogue, 2 Pet. 1, 7 L. ed. 327, was decided in 1829 , this court has consistently held that the primary purpose of our patent laws is not the creation of private fortunes for the owners of patents, but is "to promote the progress of science and the useful arts" (Constitution, art. 1, $\S 8)$,- an object and purpose authoritatively expressed by Mr. Justice Story, in that decision, saying:

"While one great object [of our patent laws] was, by holding out a reasonable reward to inventors and giving them an exclusive right to their inventions for a limited period, to stimulate the efforts of genius, the main object was 'to promote the progress of science and useful arts."'...

These rules of law make it very clear that the scope of the grant which may be made to an inventor in a patent, pursuant to the statute, must be limited to the invention described in the claims of his patent; and to determine what grant may lawfully be so made we must hold fast to the language of the act of Congress providing for it, which is found in two sections of the Revised Statutes. Section 4886 (Comp. Stat. 1913, § 9430) provides that "any person who has invented or discovered any new and useful art, machine, manufacture or composition of matter, or any new and useful improvement thereof, . . may . . . obtain a patent therefor;" and $\S$ 4884 (Comp. Stat. 1913, § 9428), provides that such patent when obtained "shall contain ... a grant to the patentee, his heirs or assigns ... of the exclusive right to . . . use . . . the invention or discovery."...

Plainly, this language of the statute and the established rules to which we have referred restrict the patent granted on a machine, such as we have in this case, to the mechanism described in the patent as necessary to produce the described results. It is not concerned with and has nothing to do with the materials with which or on which the machine operates. The grant is of the exclusive right to use the mechanism to produce the result with any appropriate material, and the materials with which the machine is operated are no part of the patented machine or of the combination which produces the patented result. The difference is clear and vital between the exclusive right to use the machine, which the law gives to the inventor, and the right to use it exclusively with prescribed materials to which such a license notice 
as we have here seeks to restrict it. The restrictions of the law relate to the useful and novel features of the machine which are described in the claims of the patent; they have nothing to do with the materials used in the operation of the machine; while the notice restrictions have nothing to do with the invention which is patented, but relate wholly to the materials to be used with it. Both in form and in substance the notice attempts a restriction upon the use of the supplies only, and it cannot, with any regard to propriety in the use of language, be termed a restriction upon the use of the machine itself.

Whatever the right of the owner may be to control by restriction the materials to be used in operating the machine, it must be a right derived through the general law from the ownership of the property in the machine, and it cannot be derived from or protected by the patent law, which allows a grant only of the right to an exclusive use of the new and useful discovery which has been made,- - this and nothing more....

The construction of the patent law which justifies as valid the restriction of patented machines, by notice, to use with unpatented supplies necessary in the operation of them, but which are no part of them, is believed to have originated in Heaton-Peninsular Button-Fastener Co. v. Eureka Specialty Co., 77 Fed. 288 (which has come to be widely referred to as the Button-Fastener Case), decided by the circuit court of appeals of the sixth circuit in 1896. In this case the court, recognizing the pioneer character of the decision it was rendering speaks of the "novel restrictions" which it is considering, and says that it is called upon "to mark another boundary line around the patentee's monopoly which will debar him from engrossing the market for an article not the subject of a patent," which it declined to do.

This decision proceeds upon the argument that, since the patentee may withhold his patent altogether from public use, he must logically and necessarily be permitted to impose any conditions which he chooses upon any use which he may allow of it. The defect in this thinking springs from the substituting of inference and argument for the language of the statute, and from failure to distinguish between the rights which are given to the inventor by the patent law and which he may assert against all the world through an infringement proceeding, and rights which he may create for himself by private contract, which, however, are subject to the rules of general, as distinguished from those of the patent, law. While it is true that under the statutes as they were (and now are) a patentee might withhold his 
INNOVATION AND COMPETITION POLICY

Hovenkamp
Chap. 2, Page 23

Jan, 2013

patented machine from public use, yet if he consented to use it himself or through others, such use immediately fell within the terms of the statute, and, as we have seen, he is thereby restricted to the use of the invention as it is described in the claims of his patent, and not as it may be expanded by limitations as to materials and supplies necessary to the operation of it, imposed by mere notice to the public.

The high standing of the court rendering this decision and the obvious possibilities for gain in the method which it approved led to an immediate and widespread adoption of the system, in which these restrictions expanded into more and more comprehensive forms until at length the case at bar is reached, with a machine sold and paid for, yet claimed still to be subject not only to restriction as to supplies to be used, but also subject to any restrictions or conditions as to use or royalty which the company which authorized its sale may see fit, after the sale, from time to time to impose. The perfect instrument of favoritism and oppression which such a system of doing business, if valid, would put into the control of the owner of such a patent, should make courts astute, if need be, to defeat its operation. If these restrictions were sustained, plainly the plaintiff might, for its own profit or that of its favorites, by the obviously simple expedient of varying its royalty charge, ruin anyone unfortunate enough to be dependent upon its confessedly important improvements for the doing of business.....

The exclusive right to "vend" a patented article is derived from the same clause of the section of the statute which gives the exclusive right to "use" such an article, and following the decision of the Button-Fastener Case, it was widely contended as obviously sound, that the right existed in the owner of a patent to fix a price at which the patented article might be sold and resold under penalty of patent infringement.... The statutory authority to grant the exclusive right to "use" a patented machine is not greater, indeed, it is precisely the same, as the authority to grant the exclusive right to "vend," and, looking to that authority, for the reasons stated in this opinion, we are convinced that the exclusive right granted in every patent must be limited to the invention described in the claims of the patent, and that it is not competent for the owner of a patent, by notice attached to its machine, to, in effect, extend the scope of its patent monopoly by restricting the use of it to materials necessary in its operation, but which are no part of the patented invention, or to send its machines forth into the channels of trade of the country subject to conditions as to use or royalty to be paid, to be imposed thereafter at the discretion of such patent owner. The patent law furnishes no warrant for such a practice, and the cost, 
INNOVATION AND COMPETITION POLICY

Hovenkamp
Chap. 2, Page 24

Jan., 2013

inconvenience, and annoyance to the public which the opposite conclusion would occasion forbid it.

It is argued as a merit of this system of sale under a license notice that the public is benefited by the sale of the machine at what is practically its cost, and by the fact that the owner of the patent makes its entire profit from the sale of the supplies with which it is operated. This fact, if it be a fact, instead of commending, is the clearest possible condemnation of, the practice adopted, for it proves that, under color of its patent, the owner intends to and does derive its profit, not from the invention on which the law gives it a monopoly, but from the unpatented supplies with which it is used, and which are wholly without the scope of the patent monopoly, thus in effect extending the power to the owner of the patent to fix the price to the public of the unpatented supplies as effectively as he may fix the price on the patented machine.

We are confirmed in the conclusion which we are announcing by the fact that since the decision of Henry v. A. B. Dick Co. supra, the Congress of the United States, the source of all rights under patents, as if in response to this decision, has enacted a law making it unlawful for any person engaged in interstate commerce "to lease or make a sale or contract for sale of goods, . . . machinery, supplies or other commodities, whether patented or unpatented, for use, consumption or resale . . . or fix a price charged therefor, ... on the condition, agreement or understanding that the lessee or purchaser thereof shall not use ... the goods . . . machinery, supplies or other commodities of a competitor or competitors of the lessor or seller, where the effect of such lease, sale, or contract for sale, or such condition, agreement or understanding may be to substantially lessen competition or tend to create a monopoly in any line of commerce."

[The patentee's] restriction is invalid because such a film is obviously not any part of the invention of the patent in suit; because it is an attempt, without statutory warrant, to continue the patent monopoly in this particular character of film after it has expired, and because to enforce it would be to create a monopoly in the manufacture and use of moving picture films, wholly outside of the patent in suit and of the patent law as we have interpreted it.....

Assuming that the plaintiff has been paid an average royalty of $\$ 5$ on each machine sold, prescribed in the license agreement, it has already received over $\$ 200,000$ for the use of its patented improvement, which 
INNOVATION AND COMPETITION POLICY

Hovenkamp
Chap. 2, Page 25

Jan, 2013

relates only to the method of using the films which another had invented, and yet it seeks by this device to collect during the life of the patent in suit what would doubtless aggregate many times this amount for the use of this same invention, after its machines have been sold and paid for.

A restriction which would give to the plaintiff such a potential power for evil over an industry which must be recognized as an important element in the amusement life of the nation, under the conclusions we have stated in this opinion, is plainly void, because wholly without the scope and purpose of our patent laws, and because, if sustained, it would be gravely injurious to that public interest, which we have seen is more a favorite of the law than is the promotion of private fortunes.

\section{Mr. Justice Holmes, dissenting:}

I suppose that a patentee has no less property in his patented machine than any other owner, and that, in addition to keeping the machine to himself, the patent gives him the further right to forbid the rest of the world from making others like it. In short, for whatever motive, he may keep his device wholly out of use. Continental Paper Bag Co. v. Eastern Paper Bag Co. 210 U. S. 405, 422. So much being undisputed, I cannot understand why he may not keep it out of use unless the licensee, or, for the matter of that, the buyer, will use some unpatented thing in connection with it. Generally speaking, the measure of a condition is the consequence of a breach, and if that consequence is one that the owner may impose unconditionally, he may impose it conditionally upon a certain event.

No doubt this principle might be limited or excluded in cases where the condition tends to bring about a state of things that there is a predominant public interest to prevent. But there is no predominant public interest to prevent a patented teapot or film feeder from being kept from the public, because, as I have said, the patentee may keep them tied up at will while his patent lasts. Neither is there any such interest to prevent the purchase of the tea or films that is made the condition of the use of the machine. The supposed contravention of public interest sometimes is stated as an attempt to extend the patent law to unpatented articles, which of course it is not, and more accurately as a possible domination to be established by such means. But the domination is one only to the extent of the desire for the teapot or film feeder, and if the owner prefers to keep the pot or the feeder unless you will buy his tea or films, I cannot see, in allowing him the right to do so, anything more than an ordinary incident of ownership, or, at most, a 
INNOVATION AND COMPETITION POLICY

Hovenkamp
Chap. 2, Page 26

Jan., 2013

consequence of the Paper Bag Case, on which, as it seems to me, this case ought to turn. See Grant v. Raymond, 6 Pet. 218, 242, 8 L. ed. 376, 384.

.... I confine myself to expressing my views upon the general and important questions upon which I have the misfortune to differ from the majority of the court. I leave on one side the question of the effect of the Clayton Act, as the court had done, and also what I might think if the Paper Bag Case were not upheld, or if the question were upon the effect of a combination of patents such as to be contrary to the policy that I am bound to accept from the Congress of the United States.

Mr. Justice McKenna and Mr. Justice Van Devanter concur in this dissent.

\section{CARBICE CORP. OF AMERICA V. AMERICAN PATENTS DEVELOPMENT CORP. 283 U.S. 27 (1931)}

Mr. Justice Brandeis delivered the opinion of the Court:

The American Patents Development Corporation, as owner of United States Patent No. 1,595,426, and the Dry Ice Corporation, as exclusive licensee, brought this suit in the federal court for eastern New York to enjoin contributory infringement by the Carbice Company, for an accounting of profits, and for damages. The defendant denied both the validity of the patent and the alleged infringement. The District Court, without passing upon validity, dismissed the bill on the ground that infringement had not been shown, 25 F. (2d) 730. The Circuit Court of Appeals held the patent valid and infringed, 38 F. (2d) 62.

Solid carbon dioxide has a temperature of about 110 below zero. When it "melts," it passes directly into a dry gaseous state-the gas having a like temperature and being in volume about 500 times that of the solid. These properties makes the solid dioxide an excellent dry refrigerant for foodstuffs, particularly for the shipment of ice cream. The refrigerating transportation package, which is the subject of the patent in suit, is made up in this way: Near the middle of the outer box or carton in which the ice cream or other foodstuff is to be shipped, there is placed, in a small container, a quantity of solid carbon dioxide. So placed, this refrigerant is relatively enduring because it is doubly protected from the exterior heat by the ice cream which surrounds it and by the evaporating gas which excludes 
INNOVATION AND COMPETITION POLICY

Hovenkamp
Chap. 2, Page 27

Jan, 2013

air and moisture from the shipping case. The ice cream is kept frozen by both the solid and the gaseous dioxide. Although the cost of solid dioxide is about ten times that of water ice, such use is said to have revolutionized the transportation of ice cream, as in this may shipping and handling charges are greatly reduced and the messiness incident to the employment of water ice is eliminated.

The patent in suit is not for solid carbon dioxide. That article and its properties as a refrigerant have been long known to the public. The patent is not for a machine for making solid carbon dioxide. Nor is it for a process for making or using that substance. The Patent Office rejected an application for a process patent. The patent is said to be for a manufacture. The specifications outline the method of construction and use; and a typical claim (6) is for a "transportation package consisting of a protective casing of insulating material having packed therein a quantity of frozen carbon dioxide in an insulating container and a quantity of freezable product in freezing proximity to said frozen carbon dioxide and the gas evaporated therefrom, arranged so that said frozen carbon dioxide is less accessible for exterior heat than said freezable products."

The sole business of the Dry Ice Corporation is the manufacture of solid carbon dioxide which it sells under the name of "DryIce." It does not make or sell transportation packages in which solid carbon dioxide is used as a refrigerant. It does not issue to other concerns licenses to make such packages upon payment of a stipulated royalty. It does not formally license buyers of its dry ice to use the invention in suit. But each invoice for solid dioxide sold by it bears this notice. "The merchandise herein described is shipped upon the following condition: That DryIce shall not be used except in DryIce cabinets or other containers or apparatus provided or approved by the DryIce Corporation of America; and the DryIce Cabinets or other containers or apparatus provided or approved by the DryIce Corporation of America shall be refrigerated or used only with DryIce. These uses of DryIce are fully covered by our Basic Method and Apparatus Patent No. 1,511,306. Granted October 14th, 1924, and other Patents Pending." The patent in suit, No. 1,595,426, issued August 10, 1926, is not named in the invoice; but it has been assumed that thereby the Dry Ice Corporation extends to each of its customers, buyers of solid carbon dioxide, a license to use the invention without the payment of royalty. The restrictions as to the purchase of cartons set forth in the invoices of the corporation appear not to have been insisted upon by it. 
The Carbice Corporation also manufactures solid carbon dioxide. It is charged with contributory infringement because it sells its product to customers of the Dry Ice Corporation with knowledge that the dioxide is to be used by the purchaser in transportation packages like those described in the patent. The Carbice Corporation challenges the validity of the patent and denies infringement. Whether the transportation package described is a patentable invention we need not determine. For even if it is, no relief can be granted.

The invention claimed is for a particular kind of package employing solid carbon dioxide in a new combination. If the patent is valid the owner can, of course, prohibit entirely the manufacture, sale, or use of such packages, Continental Paper Bag Co. v. Eastern Paper Bag Co., 210 U. S. 405. Or it can grant licenses upon terms consistent with the limited scope of the patent monopoly, United States v. General Electric Co., 272 U. S. 476, 489. It may charge a royalty or license fee. But it may not exact as the condition of a license that unpatented materials used in connection with the invention shall be purchased only from the licensor; and if it does so, relief against one who supplies such unpatented materials will be denied. The limited monopoly to make, use, and vend an article may not be "expanded by limitations as to materials and supplies necessary to the operation of it." Motion Picture Patents Co. v. Universal Film Manufacturing Co., 243 U. S. $502,515$.

The relief here sought is indistinguishable from that denied in the Motion Picture Case. There, it was held that to permit the patent-owner to "derive its profit, not from the invention on which the law gives it a monopoly, but from the unpatented supplies with which it is used" is "wholly without the scope of the patent monopoly." Page 517 of 243 U. S. If a monopoly could be so expanded, the owner of a patent for a product might conceivably monopolize the commerce in a large part of unpatented materials used in its manufacture. The owner of a patent for a machine might thereby secure a partial monopoly on the unpatented supplies consumed in its operation. The owner of a patent for a process might secure a partial monopoly on the unpatented material employed in it. The owner of the patent in suit might conceivably secure a limited monopoly for the supplying not only of solid carbon dioxide, but also of the ice cream and other foods, as well as the cartons in which they are shipped. The attempt to limit the licensee to the use of unpatented materials purchased from the licensor is comparable to the attempt of a patentee to fix the price at which the patented article may be resold. Bauer \& Cie v. O’Donnell, 229 U. S. 
1... [C]ourts deny relief against those who disregard the limitations sought to be imposed by the patentee beyond the legitimate scope of its monopoly.

Plaintiffs seek to distinguish the Motion Picture Case from that at bar, by pointing out that there, as in Henry v. A. B. Dick Co., 224 U. S. 1, the unpatented supplies, over which the licensor sought to extend its monopoly, were merely used in the patented machines, whereas here the unpatented refrigerant is one of the necessary elements of the patented product. And to distinguish the case at bar from Morgan Envelope Co. v. Albany Perforated Wrapping Paper Co., 152 U. S. 425, 433, it is pointed out that the Carbice Corporation is furnishing not a passive element in the combination, like the paper in the Morgan Envelope fixture, but the dynamic element which produces refrigeration. These distinctions are without legal significance. Infringement, whether direct or contributory, is essentially a tort, and implies invasion of some right of the patentee. The Dry Ice Corporation has no right to be free from competition in the sale of solid carbon dioxide. Control over the supply of such unpatented material is beyond the scope of the patentee's monopoly; and this limitation, inherent in the patent grant, is not dependent upon the peculiar function or character of the unpatented material or on the way in which it is used. Relief is denied because the Dry Ice Corporation is attempting, without sanction of law, to employ the patent to secure a limited monopoly of unpatented material used in applying the invention. The present attempt is analogous to the use of a patent as an instrument for restraining commerce which was condemned, under the Sherman Anti-Trust Law, in Standard Sanitary Mfg. Co. v. United States, 226 U. S. 20.

Reversed.

\section{NOTES AND QUESTIONS}

1. Anticompetitive ties have been illegal since the Supreme Court's decision in Motion Picture Patents Co. But what makes a tie "anticompetitive"? How exactly do ties harm consumers? How do they harm competition?

Nearly all the competitive harm that courts have claimed to see in tying cases can be divided into two types: leverage and foreclosure. Under the leverage theory, a firm with a monopoly in one good can create a monopoly in a second good by tying sales of the second good to the first. In other words, the firm uses its market power in the tying 
good to "leverage" monopoly profits in the tied good. Consumers are harmed because the tie forces them to pay more for the tied good than they would if there were no tie. HERBERT HOVENKAMP, FEDERAL Antitrust Policy: The LAW OF COMPETITION AND ITS PRACTICE $\S$ 10.6a (4th ed. 2011). Although courts still occasionally condemn tieins under this theory, leveraging has largely been discredited. A buyer who needs both the tying and tied products is indifferent as to how the price is allocated between the two. Its willingness to pay is determined by the value it places on the combination. For example, if the purchasers of a printer and ink generally value the combination at $\$ 100$, then a printer monopolist charging $\$ 90$ for the printer alone cannot profitably tie ink for more than $\$ 10$, regardless of its market power in the printer. Moreover, so long as the purchasers can get the combination for $\$ 100$, they will be indifferent as to whether they pay $\$ 100$ for the printer and $\$ 0$ for the ink, or $\$ 90$ for the printer and $\$ 10$ for the ink, or some other price allocation. Thus, the critique of leveraging theory shows that a seller does not gain any additional monopoly over an unpatented product by tying it to the patented product, even if the seller enjoys market power in the market for the patented product. See Ward S. Bowman, Jr., Tying Arrangements and the Leverage Problem, 67 Yale L.J. 19 (1957); Richard S. Markovits, Tie-ins, Leverage, and the American Antitrust Laws, 80 YALE L.J. 195 (1970); Richard A. Posner, The Chicago School of Antitrust Analysis, 127 U. PA. L. REV. 925 (1979).

While leverage theory has lost traction over the last several decades, foreclosure remains apt. Foreclosure occurs when a tying arrangement unreasonably limits the opportunities of rivals, typically in the tied product market. While power in the tying product may be necessary under a foreclosure theory, the real gravamen of the offense is exclusion in the tied product market. To that end, are there important differences between the effects of the tie in Motion Picture Patents from those in Carbice? The tie in the first case threatened to monopolize the motion picture industry, while no one could ever have obtained a monopoly of dry ice.

2. To what extent have the antitrust laws been implicated in the tying cases up to this point? Carbice was decided 17 years after the Clayton Act was passed, and more than 40 years after the Sherman Act. 
3. Neither Motion Picture Patents Co. nor Carbice mentions patent misuse, but the doctrine underlies both decisions. Patent misuse is an affirmative defense to an infringement claim. It allows infringement defendants to avoid liability by showing that the patent holder is using the patent in a way that violates patent or antitrust law. See Chapter 7. If the court finds misuse, the patent will be unenforceable until "the patent holder can show that the misuse has been purged, or that 'the improper practice has been abandoned and that the consequences of the misuse of the patent have been dissipated." Morton Salt Co. v. G.S. Suppiger Co., 314 U.S. 488, 493 (1942)). A. B. Dick Co., Motion Pictures Patent Co., and Carbice illustrate the doctrine's development.

The late 1800s and early 1900s were a good time for American patent holders. They "enjoyed unrestrained exploitation of their patents," and there was no misuse defense. Richard Calkins, Patent Law: The Impact of the 1988 Patent Misuse Reform Act and NoerrPennington Doctrine on the Misuse Defenses and Antitrust Counterclaims, 38 DRAKE L. REV. 175, 178 (1988-1989). Recall that A. B. Dick sold its patented mimeograph machines on the condition that they could be used only with only its unpatented paper, ink, and stencils. A. B. Dick sued Sidney Henry for patent infringement after Henry sold his mimeograph to a third party along with a can of non-A. B. Dick ink. The Court rejected the argument that A. B. Dick was using the tie to extend its mimeograph monopoly to its unpatented stencils, paper, and ink - or, to look at it another way, the Court held that A. B. Dick did not misuse its patent.

In overruling $A$. B. Dick but not applying the antitrust laws, the $M P P C$ decision implicitly recognized patent misuse as an infringement defense. Just as A. B. Dick, Motion Picture Patents Co. sold its patented good (film projectors) on the condition that they be used only with its unpatented goods (films). But unlike the stencils, ink, and paper in $A$. $B$. Dick, MPPC's unpatented films couldn't be used without its patented projectors. This is important because a tie cannot create a second monopoly in the tied product unless the tied product has no untied uses." Erik Hovenkamp \& Herbert Hovenkamp, Tying Arrangements and Antitrust Harm, 92 ARIZ. L. REV. 925, 932 (2010). The fact that MPPC's films had no untied uses could have allowed the company "to monopolize the movie market by prohibiting anyone other than [MPPC] from showing its films through [MPPC's] projector." 
Given this distinction between A. B. Dick's stencils, ink, and paper and MPPC's films, the Court could have left A. B. Dick intact in cases where the tied goods had untied uses. Instead the Court tilted its head toward section 3 of the Clayton Act - an antitrust provision that outlawed tie-ins like those in A. B. Dick Co. and MPPC when they "substantially lessen competition or tend to create a monopoly"-and announced that A. B. Dick was dead. MPPC, 243 U.S. at 517-18. See HOVENKAMP, FEDERAL ANTITRUST POLICY, supra, § 5.5b.

After $M P P C$, the Supreme Court continued to find patent misuse in cases where patent holders tied sales of patented inventions to unpatented goods. In addition to Carbice, in Leitch Manufacturing Co. v. Barber Co., 302 U.S. 458, 460-463 (1938), the Court found misuse where the plaintiff tied licensing of a patented process used in road building to sales of an unpatented emulsion used in the process. Citing Carbice, the Court stated that the plaintiff's patent did not give it "the right to be free from competition in supplying unpatented material to be used in practicing the invention."

Notice that the tied goods in Carbice and Leitch were not just unpatented - they were "common commodit[ies] produced by many competitors" and "used for many purposes." It was therefore unlikely that these tie-ins could give the plaintiff-patent holders a second "monopoly.". But the Supreme Court was clear: "[E]very use of a patent as a means of obtaining a limited monopoly of unpatented material is prohibited." 302 U.S. at 463.

MPPC, Carbice, and Leitch involved accusations of contributory infringement. In each, the patent holder sued its competitors for selling unpatented goods to the patent holder's licensees. In allowing the defendants to assert patent misuse as a defense, the Supreme Court essentially held that a patent holder could not stop its rivals from "selling goods not covered by the scope of the patent."

But in Morton Salt Co. v. G.S. Suppiger Co., 314 U.S. 488, 493 (1942), the Court went a step further. Suppiger and Morton Salt manufactured and sold salt tablets. Both also made and leased machines that deposited the tablets into canned foods. Suppiger's machines were patented, and it prohibited its licensees from using any other salt tablets with its machines. Unlike the plaintiffs in the earlier cases, Suppiger accused Morton Salt of direct infringement: Suppiger alleged that 
Morton's machines violated Suppiger's patent. The trial court dismissed the complaint, but the Seventh Circuit Court of Appeals reversed because it found that Suppiger had not used its patent in a way that violated section 3 of the Clayton Act. 314 U.S. at 490. That is, the Seventh Circuit in effect held that misuse would not apply unless the defendant had violated the antitrust laws.

The Supreme Court reversed, stating that Suppiger had sued for patent infringement, and that the issue was not whether Morton Salt violated the antitrust laws but whether a court of equity would "lend its aid to protect the patent monopoly when [the patent holder] is using it as the effective means of restraining competition with its sale of an unpatented article.". The Court held that patent holders cannot sue even for direct infringement of their patents when they tie their inventions to unpatented goods. To hold otherwise would "aid[] in the creation of a limited monopoly ... not granted by the patent." Morton Salt, 314 U.S. at 491. Morton Salt therefore prevents patent holders from enforcing any of their basic patent rights where "enforcement might contribute to [their] attempt to control the market for unpatented goods"-in other words, when they misuse their patents.

\section{INTERNATIONAL SALT CO. V. UNITED STATES 332 U.S. 392 (1947)}

Mr. Justice Jackson delivered the opinion of the Court.

The Government brought this civil action to enjoin the International Salt Company, appellant here, from carrying out provisions of the leases of its patented machines to the effect that lessees would use therein only International's salt products. The restriction is alleged to violate $\S 1$ of the Sherman Act, and $\S 3$ of the Clayton Act. Upon appellant's answer and admissions of fact, the Government moved for summary judgment. . . . Judgment was granted and appeal was taken directly to this Court.

It was established by pleadings or admissions that the International Salt Company is engaged in interstate commerce in salt, of which it is the country's largest producer for industrial uses. It also owns patents on two machines for utilization of salt products. One, the "Lixator," dissolves rock salt into a brine used in various industrial processes. The other, the "Saltomat," injects salt, in tablet form, into canned products during the canning process. The principal distribution of each of these machines is 
INNOVATION AND COMPETITION POLICY

Hovenkamp
Chap. 2, Page 34

Jan., 2013

under leases which, among other things, require the lessees to purchase from appellant all unpatented salt and salt tablets consumed in the leased machines.

Appellant had outstanding 790 leases of an equal number of "Lixators," all of which leases were on appellant's standard form containing the tying clause $^{11}$ and other standard provisions; of 50 other leases which somewhat varied the terms, all but 4 contained the tying clause. It also had in effect 73 leases of 96 "Saltomats," all containing the restrictive clause. In 1944, appellant sold approximately 119,000 tons of salt, for about $\$ 500,000$, for use in these machines.

The appellant's patents confer a limited monopoly of the invention they reward. From them appellant derives a right to restrain others from making,

11 "It is further mutually agreed that the said Lixate Process Dissolver shall be installed by and at the expense of said Lessee and shall be maintained and kept in repair during the term of this lease by and at the expense of said Lessee; that the said Lixate Process Dissolver shall be used for dissolving and converting into brine only those grades of rock salt purchased by the Lessee from the Lessor at prices and upon terms and conditions hereafter agreed upon, provided:

"If at any time during the term of this lease a general reduction in price of grade of salt suitable for use in the said Lixate Process Dissolver shall be made, said Lessee shall give said Lessor an opportunity to provide a competitive grade of salt at any such competitive price quoted, and in case said Lessor shall fail or be unable to do so, said Lessee, upon continued payments of the rental herein agreed upon, shall have the privilege of continued use of the said equipment with salt purchased in the open market, until such time as said Lessor shall furnish a suitable grade of salt at the said competitive price."

It further provides as follows:

"Should said Lessee fail to pay promptly the aforesaid rental, or shall at any time discontinue purchasing its requirement of salt from said Lessor, or otherwise breach any of the terms and conditions of this lease, said Lessor shall have the right, upon 30 days' written notice of intention to do so, to remove the said Lixate Process Dissolver from the possession of said Lessee." 
vending or using the patented machines. But the patents confer no right to restrain use of, or trade in, unpatented salt. By contracting to close this market for salt against competition, International has engaged in a restraint of trade for which its patents afford no immunity from the anti-trust laws. Morton Salt Co. v. G.S. Suppiger Co., 314 U.S. 488.

Appellant contends, however, that summary judgment was unauthorized because it precluded trial of alleged issues of fact as to whether the restraint was unreasonable within the Sherman Act or substantially lessened competition or tended to create a monopoly in salt within the Clayton Act. We think the admitted facts left no genuine issue. Not only is price-fixing unreasonable, per se, United States v. SoconyVacuum Oil Co., 310 U.S. 150, but also it is unreasonable, per se, to foreclose competitors from any substantial market. Fashion Originators' Guild of America v. Federal Trade Commission, 2 Cir., 114 F.2d 80, affirmed, 312 U.S. 457 . The volume of business affected by these contracts cannot be said to be insignificant or insubstantial and the tendency of the arrangement to accomplishment of monopoly seems obvious. Under the law, agreements are forbidden which "tend to create a monopoly," and it is immaterial that the tendency is a creeping one rather than one that proceeds at full gallop; nor does the law await arrival at the goal before condemning the direction of the movement.

Appellant contends, however, that the "Lixator" contracts are saved from unreasonableness and from the tendency to monopoly because they provided that if any competitor offered salt of equal grade at a lower price, the lessee should be free to buy in the open market, unless appellant would furnish the salt at an equal price; and the "Saltomat" agreements provided that the lessee was entitled to the benefit of any general price reduction in lessor's salt tablets. The "Lixator" provision does, of course, afford a measure of protection to the lessee, but it does not avoid the stifling effect of the agreement on competition. The appellant had at all times priority on the business at equal prices. A competitor would have to undercut appellant's price to have any hope of capturing the market, while appellant could hold that market by merely meeting competition. We do not think this concession relieves the contract of being a restraint of trade, albeit a less harsh one than would result in the absence of such a provision. The "Saltomat" provision obviously has no effect of legal significance since it gives the lessee nothing more than a right to buy appellant's salt tablets at appellant's going price. All purchases must in any event be of appellant's product. 
INNOVATION AND COMPETITION POLICY

Hovenkamp
Chap. 2, Page 36

Jan., 2013

Appellant also urges that since under the leases it remained under an obligation to repair and maintain the machines, it was reasonable to confine their use to its own salt because its high quality assured satisfactory functioning and low maintenance cost. The appellant's rock salt is alleged to have an average sodium chloride content of $98.2 \%$. Rock salt of other producers, it is said, "does not run consistent in sodium chloride content and in many instances runs as low as $95 \%$ of sodium chloride." This greater percentage of insoluble impurities allegedly disturbs the functioning of the "Lixator" machine. A somewhat similar claim is pleaded as to the "Saltomat."

Of course, a lessor may impose on a lessee reasonable restrictions designed in good faith to minimize maintenance burdens and to assure satisfactory operation. We may assume, as matter of argument, that if the "Lixator" functions best on rock salt of average sodium chloride content of $98.2 \%$, the lessee might be required to use only salt meeting such a specification of quality. But it is not pleaded, nor is it argued, that the machine is allergic to salt of equal quality produced by any one except International. If others cannot produce salt equal to reasonable specifications for machine use, it is one thing; but it is admitted that, at times, at least, competitors do offer such a product. They are, however, shut out of the market by a provision that limits it, not in terms of quality, but in terms of a particular vendor. Rules for use of leased machinery must not be disguised restraints of free competition, though they may set reasonable standards which all suppliers must meet ....

\section{NOTES AND QUESTIONS}

1. What was the competitive harm that prompted the government to bring this action under the antitrust laws? Surely the defendant was not threatening to create a monopoly in salt. Could tying salt create a monopoly in the patented machine?

2. International Salt's observation that a patent confers a "limited monopoly" effectively migrated the law of tying arrangements from patent doctrine (misuse) to antitrust, and for the next sixty years the Supreme Court "presumed" sufficient market power to make a tying arrangement anticompetitive when the tying product was patented. How sensible is that presumption? 
INNOVATION AND COMPETITION POLICY

Hovenkamp
Chap. 2, Page 37

Jan, 2013

3. Take another look at the lease agreement in the Court's footnote. International Salt required buyers of its patented Saltomats and Lixators (the tying products) to purchase its unpatented salt (the tied product) only if International Salt matched the market price for salt. This was certainly a tying arrangement-but did it allow International Salt to engage in price discrimination? See John L. Peterman, The International Salt Case, 22 J.L. \& ECON. 351, 356 (1979) ("[C]harging the competitive price would at most cover International's cost of supplying salt. There would be no margin on salt through which International might be said to charge amounts for Lixators which vary according to intensity of use."). This tends to support the defendant's argument that its real purpose was to guarantee the quality of the salt used in the machine.

\section{SIEGEL V. CHICKEN DELIGHT, INC. 448 F.2d 43 (9th Cir. 1971)}

\section{MERRILL, Circuit Judge:}

This antitrust suit is a class action in which certain franchisees of Chicken Delight seek treble damages for injuries allegedly resulting from illegal restraints imposed by Chicken Delight's standard form franchise agreements. The restraints in question are Chicken Delight's contractual requirements that franchisees purchase certain essential cooking equipment, dry-mix food items, and trade-mark bearing packaging exclusively from Chicken Delight as a condition of obtaining a Chicken Delight trade-mark license. These requirements are asserted to constitute a tying arrangement, unlawful per se under $\S 1$ of the Sherman Act, 15 U.S.C. $\S 1$.

Over its eighteen years existence, Chicken Delight has licensed several hundred franchisees to operate home delivery and pick-up food stores. It charged its franchisees no franchise fees or royalties. Instead, in exchange for the license granting the franchisees the right to assume its identity and adopt its business methods and to prepare and market certain food products under its trade-mark, Chicken Delight required its franchisees to purchase a specified number of cookers and fryers and to purchase certain packaging supplies and mixes exclusively from Chicken Delight. The prices fixed for these purchases were higher than, and included a percentage markup which exceeded that of, comparable products sold by competing suppliers.

In order to establish that there exists an unlawful tying arrangement plaintiffs must demonstrate First, that the scheme in question involves two 
INNOVATION AND COMPETITION POLICY

Hovenkamp
Chap. 2, Page 38

Jan., 2013

distinct items and provides that one (the tying product) may not be obtained unless the other (the tied product) is also purchased. Times-Picayune Publishing Co. v. United States, 345 U.S. 594, 613-614 (1953). Second, that the tying product possesses sufficient economic power appreciably to restrain competition in the tied product market. Northern Pacific R. Co. v. United States, 356 U.S. 1, 6 (1958). Third, that a "not insubstantial" amount of commerce is affected by the arrangement. International Salt Co. v. United States, 332 U.S. 392 (1947). Chicken Delight concedes that the third requirement has been satisfied. It disputes the existence of the first two. Further it asserts that, even if plaintiffs should prevail with respect to the first two requirements, there is a fourth issue: whether there exists a special justification for the particular tying arrangement in question. United States v. Jerrold Electronics Corp., 187 F.Supp. 545 (E.D.Pa.1960), aff'd per curiam, 365 U.S. 567 (1961).

\section{Two Products}

The District Court ruled that the license to use the Chicken Delight name, trade-mark, and method of operations was "a tying item in the traditional sense," 311 F.Supp. at 849 , the tied items being the cookers and fryers, packaging products, and mixes.

The court's decision to regard the trade-mark or franchise license as a distinct tying item is not without precedent. In Susser v. Carvel Corp., 332 F.2d 505 (2d Cir. 1964), all three judges regarded as a tying product the trade-mark license to ice cream outlet franchisees, who were required to purchase ice cream, toppings and other supplies from the franchisor. See also Baker v. Simmons Co., 307 F.2d 458, 466-469 (1st Cir. 1962). Nevertheless, Chicken Delight argues that the District Court's conclusion conflicts with the purposes behind the strict rules governing the use of tying arrangements.

The hallmark of a tie-in is that it denies competitors free access to the tied product market, not because the party imposing the arrangement has a superior product in that market, but because of the power or leverage exerted by the tying product. Northern Pac. R. Co. v. United States, supra. Rules governing tying arrangements are designed to strike, not at the mere coupling of physically separable objects, but rather at the use of a dominant desired product to compel the purchase of a second, distinct commodity. Times-Picayune Publishing Co. v. United States, supra, 345 U.S. at 614. In effect, the forced purchase of the second, tied product is a price exacted for 
the purchase of the dominant, tying product. By shutting competitors out of the tied product market, tying arrangements serve hardly any purpose other than the suppression of competition. Standard Oil Co. v. United States, 337 U.S. 293, 305-306 (1949).

Chicken Delight urges us to hold that its trade-mark and franchise licenses are not items separate and distinct from the packaging, mixes, and equipment, which it says are essential components of the franchise system. To treat the combined sale of all these items as a tie-in for antitrust purposes, Chicken Delight maintains, would be like applying the antitrust rules to the sale of a car with its tires or a left shoe with the right. Therefore, concludes Chicken Delight, the lawfulness of the arrangement should not be measured by the rules governing tie-ins. We disagree.

In determining whether an aggregation of separable items should be regarded as one or more items for tie-in purposes in the normal cases of sales of products the courts must look to the function of the aggregation. Consideration is given to such questions as whether the amalgamation of products resulted in cost savings apart from those reductions in sales expenses and the like normally attendant upon any tie-in, and whether the items are normally sold or used as a unit with fixed proportions.

Where one of the products sold as part of an aggregation is a trademark or franchise license, new questions are injected. In determining whether the license and the remaining ("tied") items in the aggregation are to be regarded as distinct items which can be traded in distinct markets consideration must be given to the function of trade-marks.

The historical conception of a trade-mark as a strict emblem of source of the product to which it attaches has largely been abandoned. The burgeoning business of franchising has made trade-mark licensing a widespread commercial practice and has resulted in the development of a new rationale for trade-marks as representations of product quality. This is particularly true in the case of a franchise system set up not to distribute the trade-marked goods of the franchisor, but, as here, to conduct a certain business under a common trade-mark or trade name. Under such a type of franchise, the trade-mark simply reflects the goodwill and quality standards of the enterprise which it identifies. As long as the system of operation of the franchisees lives up to those quality standards and remains as represented by the mark so that the public is not misled, neither the protection afforded the trade-mark by law nor the value of the trade-mark to 
INNOVATION AND COMPETITION POLICY

Hovenkamp
Chap. 2, Page 40

Jan., 2013

the licensee depends upon the source of the components.

This being so, it is apparent that the goodwill of the Chicken Delight trade-mark does not attach to the multitude of separate articles used in the operation of the licensed system or in the production of its end product. It is not what is used, but how it is used and what results that have given the system and its end product their entitlement to trade-mark protection. It is to the system and the end product that the public looks with the confidence that established goodwill has created.

Thus, sale of a franchise license, with the attendant rights to operate a business in the prescribed manner and to benefit from the goodwill of the trade name, in no way requires the forced sale by the franchisor of some or all of the component articles. Just as the quality of a copyrighted creation cannot by a tie-in be appropriated by a creation to which the copyright does not relate, United States v. Paramount Pictures, Inc., 334 U.S. 131 (1948), so here attempts by tie-in to extend the trade-mark protection to common articles (which the public does not and has no reason to connect with the trade-mark) simply because they are said to be essential to production of that which is the subject of the trade-mark, cannot escape antitrust scrutiny.

Chicken Delight's assertions that only a few essential items were involved in the arrangement does not give us cause to reach a different conclusion. The relevant question is not whether the items are essential to the franchise, but whether it is essential to the franchise that the items be purchased from Chicken Delight. This raises not the issue of whether there is a tie-in but rather the issue of whether the tie-in is justifiable, a subject to be discussed below.

We conclude that the District Court was not in error in ruling as matter of law that the arrangement involved distinct tying and tied products.

\section{Economic Power}

Under the per se theory of illegality, plaintiffs are required to establish not only the existence of a tying arrangement but also that the tying product possesses sufficient economic power to appreciably restrain free competition in the tied product markets.

Chicken Delight points out that while it was an early pioneer in the fast food franchising field, the record establishes that there has recently been a 
dramatic expansion in this area, with the advent of numerous firms, including many chicken franchising systems, all competing vigorously with each other. Under the circumstances, it contends that the existence of the requisite market dominance remained a jury question.

The District Court ruled, however, that Chicken Delight's unique registered trade-mark, in combination with its demonstrated power to impose a tie-in, established as matter of law the existence of sufficient market power to bring the case within the Sherman Act.

We agree. In Fortner Enterprises, Inc. v. United States Steel Corp., 394 U. S. 495, 502-503 (1969), it is stated:

"The standard of 'sufficient economic power' does not, as the District Court held, require that the defendant have a monopoly or even a dominant position throughout the market for the tying product. Our tie-in cases have made unmistakably clear that the economic power over the tying product can be sufficient even though the power falls far short of dominance and even though the power exists only with respect to some of the buyers in the market."

Later, at page 504, it is stated:

"Accordingly, the proper focus of concern is whether the seller has the power to raise prices, or impose other burdensome terms such as a tie-in, with respect to any appreciable number of buyers within the market."

In United States v. Loew's, Inc., 371 U.S. 38, 45 (1962), it is stated:

"Even absent a showing of market dominance, the crucial economic power may be inferred from the tying product's desirability to consumers or from uniqueness in its attributes."

It can hardly be denied that the Chicken Delight trade-mark is distinctive; that it possesses goodwill and public acceptance unique to it and not enjoyed by other fast food chains.

It is now clear that sufficient economic power is to be presumed where 
INNOVATION AND COMPETITION POLICY

Hovenkamp
Chap. 2, Page 42

Jan., 2013

the tying product is patented or copyrighted. United States v. Loew's, Inc., supra; United States v. Paramount Pictures, Inc., supra; International Salt Co. v. United States, supra.

In Fortner, 394 U.S. at page 505, it is stated:

"Uniqueness confers economic power only when other competitors are in some way prevented from offering the distinctive product themselves. Such barriers may be legal, as in the case of patented and copyrighted products, e.g., International Salt; Lowe's, or physical, as when the product is land, e. g., Northern Pacific."

Just as the patent or copyright forecloses competitors from offering the distinctive product on the market, so the registered trade-mark presents a legal barrier against competition. It is not the nature of the public interest that has caused the legal barrier to be erected that is the basis for the presumption, but the fact that such a barrier does exist. Accordingly we see no reason why the presumption that exists in the case of the patent and copyright does not equally apply to the trade-mark.

Thus we conclude that the District Court did not err in ruling as matter of law that the tying product-the license to use the Chicken Delight trademark -possessed sufficient market power to bring the case within the Sherman Act.

\section{Justification}

Chicken Delight maintains that, even if its contractual arrangements are held to constitute a tying arrangement, it was not an unreasonable restraint under the Sherman Act. Three different bases for justification are urged.

First, Chicken Delight contends that the arrangement was a reasonable device for measuring and collecting revenue. There is no authority for justifying a tying arrangement on this ground. Unquestionably, there exist feasible alternative methods of compensation for the franchise licenses, including royalties based on sales volume or fees computed per unit of time, which would neither involve tie-ins nor have undesirable anticompetitive consequences.

Second, Chicken Delight advances as justification the fact that when it 
first entered the fast food field in 1952 it was a new business and was then entitled to the protection afforded by United States v. Jerrold Electronics Corp., supra, 187 F.Supp. 545. As to the period here involved-1963 to 1970 - it contends that transition to a different arrangement would be difficult if not economically impossible.

We find no merit in this contention. Whatever claim Chicken Delight might have had to a new business defense in 1952-a question we need not decide- the defense cannot apply to the 1963-70 period. To accept Chicken Delight's argument would convert the new business justification into a perpetual license to operate in restraint of trade. See Id., 187 F.Supp. at 558, 561.

The third justification Chicken Delight offers is the "marketing identity" purpose, the franchisor's preservation of the distinctiveness, uniformity and quality of its product.

In the case of a trade-mark this purpose cannot be lightly dismissed. Not only protection of the franchisor's goodwill is involved. The licensor owes an affirmative duty to the public to assure that in the hands of his licensee the trade-mark continues to represent that which it purports to represent. For a licensor, through relaxation of quality control, to permit inferior products to be presented to the public under his licensed mark might well constitute a misuse of the mark. 15 U.S.C. $\S \S 1055$, 1127; See Note, "Quality Control and the Antitrust Laws in Trade-mark Licensing," supra.

However, to recognize that such a duty exists is not to say that every means of meeting it is justified. Restraint of trade can be justified only in the absence of less restrictive alternatives. In cases such as this, where the alternative of specification is available, the language used in Standard Oil Co. v. United States, supra, 337 U.S. at 306, in our view states the proper test, applicable in the case of trade-marks as well as in other cases:

“*** the protection of the good will of the manufacturer of the tying device-fails in the usual situation because specification of the type and quality of the product to be used in connection with the tying device is protection enough. $* * *$ The only situation, indeed, in which the protection of good will may necessitate the use of tying clauses is where specifications for a substitute would be so detailed that they could not practicably be supplied." 
INNOVATION AND COMPETITION POLICY

Hovenkamp
Chap. 2, Page 44

Jan., 2013

The District Court found factual issues to exist as to whether effective quality control could be achieved by specification in the case of the cooking machinery and the dip and spice mixes. These questions were given to the jury under instructions; and the jury, in response to special interrogatories, found against Chicken Delight.

As to the paper packaging, the court ruled as matter of law that no justification existed. It stated, $311 \mathrm{~F}$. Supp. at page 851:

"Defendants' showing on paper packaging is nothing more than a recitation of the need for distinctive packaging to be used uniformly by all franchisees in identifying the hot foods. This was not contested. However, the admissions in evidence clearly demonstrate that the tied packaging was easily specifiable. In fact, the only specifications required were printing and color. Moreover, defendants have admitted that any competent manufacturer of like products could consistently and satisfactorily manufacture the packaging products if defendants furnished specifications. Those suppliers could have sold to the franchisees through normal channels of distribution."

We agree. One cannot immunize a tie-in from the antitrust laws by simply stamping a trade-mark symbol on the tied product - at least where the tied product is not itself the product represented by the mark.

We conclude that the District Court was not in error in holding as matter of law (and upon the limited jury verdict) that Chicken Delight's contractual requirements constituted a tying arrangement in violation of $\S 1$ of the Sherman Act. Upon this aspect of the case, judgment is affirmed.

\section{The Measure of Damages}

Section 4 of the Clayton Act, 15 U.S. C. $\S 15$, provides that anyone "injured in his business or property" by reason of a violation of the antitrust laws "shall recover threefold the damages by him sustained." In determining what damages plaintiffs incurred, the District Court noted that the contracts and all written representations by Chicken Delight stated that there were no franchise fees or royalty payments and from that fact concluded that the entire price paid by the franchisees was allocable to the 
INNOVATION AND COMPETITION POLICY

Hovenkamp
Chap. 2, Page 45

Jan, 2013

tied items. Thus, the court ruled that the fact of damages equal in amount to the overcharge on the tied items (the amount by which the contract price exceeded the market price for comparable items) was established as a matter of law.

It stated, 311 F.Supp. at page 852:

"On the issue of fact of damage, this Court has determined as a matter of law that the fact of damage is established. Defense counsel persists in his argument that the upcharge in the tied products should be offset by a 'reasonable value' assessed for the Chicken Delight license. $* * *$ This Court will not attempt to restructure the system of defendants into one which is legally constituted and then allow an offset for imaginary or suppositious royalty fees. Such would be directly contrary to the avowed policy of the Sherman Act."

In this we feel the court erred.

It is by no means clear that any of the parties to the tying arrangements understood that the tying items were to be given free of charge. Indeed, the more reasonable reading of the contracts and of Chicken Delight's representations is that they stated simply that the contract prices for the tied items were to be the full compensation asked by Chicken Delight for both those items and the franchise licenses.

By its own terms, Clayton Act recovery is available only where actual injury has been suffered. Winckler \& Smith Citrus Products Co. v. Sunkist Growers, Inc., 346 F.2d 1012, 1014 (9th Cir. 1965). The question here is whether the plaintiffs have suffered injury by virtue of the unlawful arrangement to which they were subjected. That arrangement of necessity involved both tying and tied products. To ascertain whether an unlawful arrangement for the sale of products has caused injury to the purchaser, the cost or value of the products involved, free from the unlawful arrangement, must first be ascertained.

Appellants contend that since the value of the tying items must be taken into account, as matter of law appellees have suffered no injury. They reason that the value of the tying items has been conclusively evidenced by what the franchisees were willing to pay (in overcharges for the tied items) 
INNOVATION AND COMPETITION POLICY

Hovenkamp

in order to get them.
Chap. 2, Page 46

Jan., 2013

We cannot agree. The franchisees' apparent willingness to pay the ultimate cost of the arrangement is clouded by the fact that they may well have been unaware of what that cost would come to in practice. Had the full amount of the over-charge on the tied items been openly specified as the cost of the tying items, agreement might not have been forthcoming. We can hardly rule as matter of law that it would have been.

We conclude that neither the existence of damage nor its lack of existence has been established as matter of law; that factual issues remain as to the value of both tying and tied products, free from the tying arrangement; that remand for the resolution of these issues is necessary.

Upon the issue of damages, judgment is reversed and the case remanded for limited new trial.

\section{NOTES AND QUESTIONS}

1. Franchise ties like the one in Chicken Delight are similar to the product ties you saw in A. B. Dick Co., Motion Picture Patents Co., Carbice, and International Salt. The major difference is that in the franchising context, the tying good is typically the franchisor's trademark, which it licenses to its franchisees. See Roger D. Blair \& Francine Lafontaine, The Economics of Franchising 139 (2005); Benjamin Klein \& Lester F. Saft, The Law and Economics of Franchise Tying Contracts, 28 J.L. \& ECON 345, 355 (1985). The tied goods, meanwhile, are often supplies and inputs the franchisees need to run the business. Steven C. Michael, The Extent, Motivation, and Effect of Tying in Franchise Contracts, 21 MANAGERIAL \& DECISION ECON. 191, 191 (2000).

2. Just like tying firms in other contexts, franchisors want to capture as much of the consumer surplus as they can (only here, the "consumers" are the businesspeople that operate the franchises). Franchisors frequently do this through the use of variable-proportion ties. Developing a trademark can be extremely expensive, and in the absence of a tying arrangement, a franchisor might have to charge large upfront fees to cover these sunk costs. Herbert HOVENKAMP, FEDERAL ANTITRUst POLICY: THE LAW OF COMPETITION AND ITS PRACTICE $\S 10.6$ e (4th ed. 2011). On the other hand, once the trademark and business method are established, the cost of licensing the trademark to an additional franchisee may be very low and in 
some cases may approach zero. If the franchisor charged the same "monopoly" price to all franchisees, it would probably set the price higher than many franchisees would be willing to pay, and franchises that would be profitable at a lower entry price would never come about. See id. So instead the franchisor reduces the price of the tying product (the franchise license) and raises the price of the tied products (in Chicken Delight, the spices, dips, batter, paper packaging, etc). Doing this allows the franchisor to earn a high return from higher-volume franchisees, who purchase more of the tied goods, and at least some profit from lower-volume-but still profitable-franchisees.

Capturing consumer surplus is not the only reason franchisors tie their trademarks. Quality control is a major concern for franchisors. Consumers usually cannot tell how good or bad an individual franchisee's product is before they purchase it, so franchisees have incentives to cut costs by using lower-quality inputs. Klein \& Saft, supra, at 349. Because the franchise's products are standardized, consumers blame the entire franchise for, say, a bad chicken leg. See id. The individual franchisee benefits from selling lessthan-delightful chicken, while the losses from lower future demandassuming the unhappy customer does not come back - are spread across the entire Chicken Delight franchise. Id. at 349-50. A franchisor can prevent "free riding" on its trademark by requiring franchisees to purchase inputs from the franchisor or from suppliers the franchisor trusts. See id. at 35253. Empirical research on tying suggests that quality control is in fact a big reason franchisors tie goods to their trademarks. Michael, supra, at 195.

But even franchisors who appear to be doing quality control are probably also - if not only - trying to capture as much of their franchisees' surplus as they can. For instance:

Chicken Delight diligently monitored purchase of the packaging items, but it paid little attention to inputs that could be expected to affect quality more significantly. Chicken, for example, could be purchased by franchisees from any source, as long as specifications set by the franchisor were met. Chicken Delight did have an interest in assuring that customers would not purchase chicken in a bucket that leaked, but this did not seem to be a problem. In fact, to detect franchisees that were using unauthorized ("counterfeit") packaging materials, Chicken Delight at one point employed an invisible dye that could be observed only 
under ultraviolet light. This is an odd technique if buckets from other sources are clearly inferior.

Chicken Delight monitored purchase of the paper products not because of quality control considerations but because it collected the franchise fee as a profit on these items .... .

Klein \& Saft, supra, at 348 (footnotes omitted). On the other hand, Chicken Delight may have been half-right. See Edward M. Iacobucci, Tying as Quality Control, 32 J. LEGAL STUDIES 435 (2003) (arguing that "inferior tied goods may not harm, and indeed may enhance, the tying good's reputation"). For an argument that empirical evidence suggests franchise ties increase the likelihood of leaky buckets, see Uri Benoliel, The Behavioral Law and Economics of Franchise Tying Contracts, 41 RUTGERS L.J. 527 (2010).

Finally, to the extent that tying reduces the upfront costs of acquiring a franchise, does it also lower the likelihood that franchisees will irrationally continue to run unprofitable businesses? See Gillian K. Hadfield, Problematic Relations: Franchising and the Law of Incomplete Contracts, 42 STAN. L. REV. 927, 952 (1990) ("A business with sunk costs, on the other hand, will continue to operate even though it has never recovered its investments in fixed costs, and it will not shut down until the amount it is losing exceeds what it would lose by simply abandoning the investment."). This would almost certainly benefit franchisees. See Paul KRUGMan \& Robin Wells, Economics 238-39 ( $2 \mathrm{~d}$ ed. 2009). Probably not, because while the franchisee's fixed costs are reduced by the tie, its variable costs are increased, and shutting down is more likely to be responsive to high variable costs.

3. Tying Requirements. In determining whether Chicken Delight's franchise agreement violated the antitrust laws, the Ninth Circuit Court applied a three-part test under which plaintiffs could prevail only if:

First, ... the scheme in question involves two distinct items and provides that one (the tying product) may not be obtained unless the other (the tied product) is also purchased. Second, . . . the tying product possesses sufficient economic power appreciably to restrain competition in the tied product market. Third, ... a "not insubstantial" amount of commerce 
INNOVATION AND COMPETITION POLICY

Hovenkamp
Chap. 2, Page 49

Jan, 2013

is affected by the arrangement.

Siegel v. Chicken Delight, Inc., 448 F.2d at 47 (citations omitted).

4. What was the basis for Chicken Delight's claim that there was no illegal tie-in? Does it strike you as plausible? Were the terms of the licensing agreement no different from "the sale of a car with its tires or a left shoe with the right," as Chicken Delight argued? Chicken Delight claimed that its trademark and franchise agreements were not "separate and distinct from the packaging, mixes, and equipment" it claimed were "essential components" of the Chicken Delight franchising system. Chicken Delight, 448 F.2d at 47-48. The Ninth Circuit Court of Appeals disagreed, stating that "the goodwill of the Chicken Delight trade-mark does not attach to the multitude of separate articles used in the operation of the licensed system or in the production of its end product."

Cf. Rick-Mik Enters., Inc. v. Equilon Enters. LLC, 532 F.3d 963, 974 n.3 (9th Cir. 2008), which concluded that the "method of doing business (the franchise) is not sold separately from the ingredients that go into the method of business." Rick-Mik, 532 F.3d at 974 (emphasis added). Would these "ingredients" include the barbecue-rib seasoning Chicken Delight "forced" on its franchisees? Chicken Delight's special batter mix? What about the packaging that bore Chicken Delight's trademark? The fryers its franchisees would use to make Chicken Delight chicken?

5. Damages-overcharge in the tied product alone? On the sum of the two products? The district court found that Chicken Delight didn't charge its franchisees royalties or fees for using its trademark but instead made its money by "overcharg[ing]" for its non-trademarked tied products. $311 \mathrm{~F}$. Supp. at 852. The lower court ruled that the plaintiffs had established damages equal to the overcharge on the tied products, but Chicken Delight argued that the overcharges on the tied products "should be offset by a 'reasonable value' assessed for the Chicken Delight license." On appeal the chain apparently claimed that the "value of the tying items" totally offset the overcharge on the tied products and that the plaintiffs had therefore suffered no harm. See 448 F.3d at 52. The district court, however, refused to "allow an offset for imaginary or suppositious royalty fees," The Ninth Circuit rejected the contention that the "value of the tying items [was] conclusively evidenced by what the franchisees were willing to pay (in overcharges for the tied items) in order to get them." But the Ninth Circuit bought Chicken Delight's proposed framework for calculating damages in 
illegal-tying cases, which basically required the court to take the sum of (a) the plaintiffs' gains from licensing the tying products and (b) the plaintiffs' losses from paying overcharges on the tied products. See id. The parties settled before the lower court had to do the math, but it's possible - maybe even "likely" - that Chicken Delight's franchisees suffered no injury from the tie. See Phillip E. Areeda \& Herbert Hovenkamp, Antitrust Law II340c (3d ed. 2008).

6. The first Chicken Delight opened in Illinois in 1952, and at one point there were more than a thousand Chicken Delights in the United States. But by the time the Siegels first sued the fast-food chain, that number had dropped to about 650. See Chicken Delight, 271 F. Supp. at 725. After the Ninth Circuit's decision in Siegel v. Chicken Delight, Inc., Chicken Delight's "main source of revenue"- the packaging and equipment it sold its franchisees_-"dried up." See History, Chicken Delight, http://www.chickendelight.com/about.htm (last visited Sept. 18, 2011). There are currently less than a dozen Chicken Delights left in the U.S. See id.

\section{QUEEN CITY PIZZA, INC. V. DOMINO'S PIZZA, INC. 124 F.3d 430 (3d Cir. 1997)}

\section{SCIRICA, Circuit Judge.}

In this appeal, we must decide whether certain franchise tying restrictions support a claim for violation of federal antitrust laws. Eleven franchisees of Domino's Pizza stores and the International Franchise Advisory Council, Inc. filed suit against Domino's Pizza, Inc., alleging violations of federal antitrust laws, breach of contract, and tortious interference with contract. The district court dismissed the antitrust claims under Fed.R.Civ.P. 12(b)(6)....

Domino's Pizza, Inc. is a fast-food service company that sells pizza through a national network of over 4200 stores. Domino's Pizza owns and operates approximately 700 of these stores. Independent franchisees own and operate the remaining 3500. Domino's Pizza, Inc. is the second largest pizza company in the United States, with revenues in excess of $\$ 1.8$ billion per year.

A franchisee joins the Domino's system by executing a standard franchise agreement with Domino's Pizza, Inc. Under the franchise 
agreement, the franchisee receives the right to sell pizza under the "Domino's" name and format. In return, Domino's Pizza receives franchise fees and royalties.

The essence of a successful nationwide fast-food chain is product uniformity and consistency. Uniformity benefits franchisees because customers can purchase pizza from any Domino's store and be certain the pizza will taste exactly like the Domino's pizza with which they are familiar. This means that individual franchisees need not build up their own good will. Uniformity also benefits the franchisor. It ensures the brand name will continue to attract and hold customers, increasing franchise fees and royalties.

For these reasons, section 12.2 of the Domino's Pizza standard franchise agreement requires that all pizza ingredients, beverages, and packaging materials used by a Domino's franchisee conform to the standards set by Domino's Pizza, Inc. Section 12.2 also provides that Domino's Pizza, Inc. "may in our sole discretion require that ingredients, supplies and materials used in the preparation, packaging, and delivery of pizza be purchased exclusively from us or from approved suppliers or distributors." Domino's Pizza reserves the right "to impose reasonable limitations on the number of approved suppliers or distributors of any product." To enforce these rights, Domino's Pizza, Inc. retains the power to inspect franchisee stores and to test materials and ingredients. Section 12.2 is subject to a reasonableness clause providing that Domino's Pizza, Inc. must "exercise reasonable judgment with respect to all determinations to be made by us under the terms of this Agreement."

Under the standard franchise agreement, Domino's Pizza, Inc. sells approximately $90 \%$ of the $\$ 500$ million in ingredients and supplies used by Domino's franchisees. These sales, worth some $\$ 450$ million per year, form a significant part of Domino's Pizza, Inc.'s profits. Franchisees purchase only $10 \%$ of their ingredients and supplies from outside sources. With the exception of fresh dough, Domino's Pizza, Inc. does not manufacture the products it sells to franchisees. Instead, it purchases these products from approved suppliers and then resells them to the franchisees at a markup.

The plaintiffs in this case are eleven Domino's franchisees and the International Franchise Advisory Council, Inc. ("IFAC"), a Michigan corporation consisting of approximately $40 \%$ of the Domino's franchisees in the United States, formed to promote their common interests. The 
plaintiffs contend that Domino's Pizza, Inc. has a monopoly in "the $\$ 500$ million aftermarket for sales of supplies to Domino's franchisees" and has used its monopoly power to unreasonably restrain trade, limit competition, and extract supra-competitive profits. Plaintiffs point to several actions by Domino's Pizza, Inc. to support their claims.

First, plaintiffs allege that Domino's Pizza, Inc. has restricted their ability to purchase competitively priced dough. Most franchisees purchase all of their fresh dough from Domino's Pizza, Inc. Plaintiffs here attempted to lower costs by making fresh pizza dough on site. They contend that in response, Domino's Pizza, Inc. increased processing fees and altered quality standards and inspection practices for store-produced dough, which eliminated all potential savings and financial incentives to make their own dough. Plaintiffs also allege Domino's Pizza, Inc. prohibited stores that produce dough from selling their dough to other franchisees, even though the dough-producing stores were willing to sell dough at a price $25 \%$ to $40 \%$ below Domino's Pizza, Inc.'s price.

Next, plaintiffs object to efforts by Domino's Pizza, Inc. to block IFAC's attempt to buy less expensive ingredients and supplies from other sources. In June 1994, IFAC entered into a purchasing agreement with FoodService Purchasing Cooperative, Inc. (FPC). Under the agreement, FPC was appointed the purchasing agent for IFAC-member Domino's franchisees. FPC was charged with developing a cooperative purchasing plan under which participating franchisees could obtain supplies and ingredients at reduced cost from suppliers other than Domino's Pizza, Inc. Plaintiffs contend that when Domino's Pizza, Inc. became aware of these efforts, it intentionally issued ingredient and supply specifications so vague that potential suppliers could not provide FPC with meaningful price quotations.

Plaintiffs also allege Domino's Pizza entered into exclusive dealing arrangements with several franchisees in order to deny FPC access to a pool of potential buyers sufficiently large to make the alternative purchasing scheme economically feasible. In addition, plaintiffs contend Domino's Pizza, Inc. commenced anti-competitive predatory pricing to shut FPC out of the market. For example, they maintain that Domino's Pizza, Inc. lowered prices on many ingredients and supplies to a level competitive with FPC's prices and then recouped lost profits by raising the price on fresh dough, which FPC could not supply. Further, plaintiffs contend Domino's 
Pizza, Inc. entered into exclusive dealing arrangements with the only approved suppliers of ready-made deep dish crusts and sauce. Under these agreements, the suppliers were obligated to deliver their entire output to Domino's Pizza, Inc. Plaintiffs allege the purpose of these agreements was to prevent FPC from purchasing these critical pizza components for resale to franchisees.

Finally, plaintiffs allege Domino's Pizza, Inc. refused to sell fresh dough to franchisees unless the franchisees purchased other ingredients and supplies from Domino's Pizza, Inc. As a result of these and other alleged practices, plaintiffs maintain that each franchisee store now pays between $\$ 3000$ and $\$ 10,000$ more per year for ingredients and supplies than it would in a competitive market. Plaintiffs allege these costs are passed on to consumers.

As noted, eleven Domino's franchisees and IFAC filed an amended complaint in United States District Court for the Eastern District of Pennsylvania against Domino's Pizza, Inc. seeking declaratory, injunctive, and compensatory relief under $\S \S 1$ and 2 of the Sherman Act, 15 U.S.C. $\S \S$ 1 and 2. The plaintiffs also sought damages for breach of contract, breach of implied covenants of good faith and fair dealing, and tortious interference with contractual relations.

Domino's Pizza, Inc. moved to dismiss the antitrust claims for failure to state a claim, contending the plaintiffs failed to allege a "relevant market," a basic pleading requirement for claims under both $\S 1$ and $\S 2$ of the Sherman antitrust act. They maintained that the relevant market defined in the complaint - the "market" in Domino's-approved ingredients and supplies used by Domino's Pizza franchisees - was invalid as a matter of law because the boundaries of the proposed relevant market were defined by contractual terms contained in the franchise agreement, and not measured by cross-elasticity of demand or product interchangeability.

The district court granted defendant's motion to dismiss with prejudice plaintiffs' federal antitrust claims.... Noting that plaintiffs did "not explicitly identify the relevant product and geographic markets in their amended complaint," the court said that "it is clear from the context, and confirmed in their memorandum in opposition to the instant motion, that Plaintiffs consider the relevant product market to be the market for ingredients and supplies among Domino's franchisees." Rejecting this concept of the relevant market, the court held that "antitrust claims 
INNOVATION AND COMPETITION POLICY

Hovenkamp
Chap. 2, Page 54

Jan., 2013

predicated upon a 'relevant market' defined by the bounds of a franchise agreement are not cognizable." The court noted that Domino's Pizza, Inc.'s power to force plaintiffs to purchase ingredients and supplies from them stemmed "not from the unique nature of the product or from its market share in the fast food franchise business, but from the franchise agreement." For that reason, plaintiffs' claims "implicate principles of contract, and are not the concern of the antitrust laws." The district court also held plaintiffs had failed adequately to allege harm to competition, "a bedrock premise of antitrust law." Because plaintiffs failed to assert a cognizable antitrust claim and there was neither diversity among the parties nor special circumstances justifying exercise of supplemental jurisdiction, the court dismissed without prejudice plaintiffs' common law claims for lack of subject matter jurisdiction.

. . Plaintiffs assert six distinct antitrust claims on appeal. First, plaintiffs allege Domino's Pizza, Inc. has monopolized the market in pizza supplies and ingredients for use in Domino's stores, in violation of $\S 2$ of the Sherman Act, 15 U.S.C. $§ 2$. In support of this contention, plaintiffs allege Domino's Pizza, Inc. has sufficient market power to control prices and exclude competition in this market. Second, plaintiffs contend Domino's Pizza, Inc. has attempted to monopolize the market for Domino's pizza supplies and ingredients, in violation of $\S 2$ of the Sherman Act. Third, plaintiffs allege Domino's Pizza, Inc.'s exclusive dealing arrangements have unreasonably restrained trade in violation of $\S 1$ of the Sherman Act, 15 U.S.C. $\S$ 1. Fourth, plaintiffs allege Domino's Pizza, Inc. imposed an unlawful tying arrangement by requiring franchisees to buy ingredients and supplies from them as a condition of obtaining fresh dough, in violation of the Sherman Act $\S 1,15$ U.S.C. $\S 1$. Fifth, plaintiffs allege Domino's Pizza, Inc. imposed an unlawful tying arrangement by requiring franchisees to buy ingredients and supplies "as a condition of their continued enjoyment of rights and services under their Standard Franchise Agreement," in violation of $\S 1$ of the Sherman Act, 15 U.S.C. $\S 1$. Sixth, plaintiffs allege Domino's Pizza, Inc. has monopoly power in a relevant "market for reasonably interchangeable franchise opportunities facing prospective franchisees," in violation of $\S 2$ of the Sherman Act, 15 U.S.C. $\S 2$. This last claim was not raised before the district court.

As we have noted, the district court held that none of the plaintiffs' antitrust claims was cognizable under federal law. We will analyze each claim in turn. 
INNOVATION AND COMPETITION POLICY

Hovenkamp
Chap. 2, Page 55

Jan, 2013

As a threshold matter, plaintiffs argue that "relevant market determinations are inherently fact intensive, and therefore are inappropriate for disposition on a Rule 12(b)(6) motion." 16). It is true that in most cases, proper market definition can be determined only after a factual inquiry into the commercial realities faced by consumers. See Eastman Kodak Co. v. Image Technical Services, Inc., 504 U.S. 451, 482 (1992). Plaintiffs err, however, when they try to turn this general rule into a per se prohibition against dismissal of antitrust claims for failure to plead a relevant market under Fed.R.Civ.P. 12(b)(6).

Plaintiffs have the burden of defining the relevant market. "The outer boundaries of a product market are determined by the reasonable interchangeability of use or the cross-elasticity of demand between the product itself and substitutes for it." Brown Shoe Co. v. U.S., 370 U.S. 294, 325. Where the plaintiff fails to define its proposed relevant market with reference to the rule of reasonable interchangeability and cross-elasticity of demand, or alleges a proposed relevant market that clearly does not encompass all interchangeable substitute products even when all factual inferences are granted in plaintiff's favor, the relevant market is legally insufficient and a motion to dismiss may be granted. See, e.g.,... Tower Air, Inc. v. Federal Exp. Corp., 956 F.Supp. 270 (E.D.N.Y.1996) ("Because a relevant market includes all products that are reasonably interchangeable, plaintiff's failure to define its market by reference to the rule of reasonable interchangeability is, standing alone, valid grounds for dismissal.”).

Plaintiffs allege Domino's Pizza, Inc. has willfully acquired and maintained a monopoly in the market for ingredients, supplies, materials and distribution services used in the operation of Domino's stores, in violation of $\S 2$ of the Sherman Act, 15 U.S.C. $\S 2$. Section 2 sanctions those "who shall monopolize, or attempt to monopolize, or combine or conspire with any other person or persons, to monopolize any part of the trade or commerce among the several states, or with foreign nations." "The offense of monopoly under $\S 2$ of the Sherman Act has two elements: (1) the possession of monopoly power in the relevant market and (2) the willful acquisition or maintenance of that power as distinguished from growth or development as a consequence of a superior product, business acumen, or historic accident." Aspen Skiing Co. v. Aspen Highlands Skiing Corp., 472 U.S. 585, 596 n. 19 (1985) (quoting United States v. Grinnell Corp., 384 U.S. 563, 570-71 (1966)).

The district court dismissed plaintiffs' $§ 2$ monopoly claims for failure 
INNOVATION AND COMPETITION POLICY

Hovenkamp
Chap. 2, Page 56

Jan., 2013

to plead a valid relevant market. Plaintiffs suggest the "ingredients, supplies, materials, and distribution services used by and in the operation of Domino's pizza stores" constitutes a relevant market for antitrust purposes. We disagree.

... "Interchangeability implies that one product is roughly equivalent to another for the use to which it is put; while there may be some degree of preference for the one over the other, either would work effectively. A person needing transportation to work could accordingly buy a Ford or a Chevrolet automobile, or could elect to ride a horse or bicycle, assuming those options were feasible." Allen-Myland, Inc. v. International Business Machines Corp., 33 F.3d 194, 206 (3d Cir.1994) (internal quotations omitted). When assessing reasonable interchangeability, "[f]actors to be considered include price, use, and qualities." Tunis Brothers, 952 F.2d at 722. Reasonable interchangeability is also indicated by "cross-elasticity of demand between the product itself and substitutes for it." Brown Shoe Co. v. U.S., 370 U.S. 294, 325 (1962). As we explained in Tunis Brothers Co., Inc. v. Ford Motor Co., 952 F.2d 715, 722 (3d Cir.1991), "products in a relevant market [are] characterized by a cross-elasticity of demand, in other words, the rise in the price of a good within a relevant product market would tend to create a greater demand for other like goods in that market." Tunis Brothers, 952 F.2d at 722.

Here, the dough, tomato sauce, and paper cups that meet Domino's Pizza, Inc. standards and are used by Domino's stores are interchangeable with dough, sauce and cups available from other suppliers and used by other pizza companies. Indeed, it is the availability of interchangeable ingredients of comparable quality from other suppliers, at lower cost, that motivates this lawsuit. Thus, the relevant market, which is defined to include all reasonably interchangeable products, cannot be restricted solely to those products currently approved by Domino's Pizza, Inc. for use by Domino's franchisees. For that reason, we must reject plaintiffs' proposed relevant market.

Of course, Domino's-approved pizza ingredients and supplies differ from other available ingredients and supplies in one crucial manner. Only Domino's-approved products may be used by Domino's franchisees without violating section 12.2 of Domino's standard franchise agreement. Plaintiffs suggest that this difference is sufficient by itself to create a relevant market in approved products. We disagree. The test for a relevant market is not commodities reasonably interchangeable by a particular plaintiff, but 
INNOVATION AND COMPETITION POLICY

Hovenkamp
Chap. 2, Page 57

Jan, 2013

"commodities reasonably interchangeable by consumers for the same purposes." United States v. E.I. du Pont de Nemours \& Co., 351 U.S. 377, 395 (1956); Tunis Brothers, 952 F.2d at 722. A court making a relevant market determination looks not to the contractual restraints assumed by a particular plaintiff when determining whether a product is interchangeable, but to the uses to which the product is put by consumers in general. Thus, the relevant inquiry here is not whether a Domino's franchisee may reasonably use both approved or non-approved products interchangeably without triggering liability for breach of contract, but whether pizza makers in general might use such products interchangeably. Clearly, they could. Were we to adopt plaintiffs' position that contractual restraints render otherwise identical products non-interchangeable for purposes of relevant market definition, any exclusive dealing arrangement, output or requirement contract, or franchise tying agreement would support a claim for violation of antitrust laws. Perhaps for this reason, no court has defined a relevant product market with reference to the particular contractual restraints of the plaintiff....

Plaintiffs argue that the Supreme Court's decision defining relevant markets in Eastman Kodak Co. v. Image Technical Services, Inc., 504 U.S. 451 (1992) requires a different outcome. We disagree.

In Kodak, the Supreme Court observed that a market is defined with reference to reasonable interchangeability. Kodak, 504 U.S. at 482. The Court held that the market for repair parts and services for Kodak photocopiers was a valid relevant market because repair parts and services for Kodak machines are not interchangeable with the service and parts used to fix other copiers. Id. Plaintiffs suggest that Kodak supports its proposed relevant market because it indicates that in some circumstances, a single brand of a product or service may constitute a relevant market. This is correct where the commodity is unique, and therefore not interchangeable with other products. But here, it is uncontested that contractual restraints aside, the sauce, dough, and other products and ingredients approved for use by Domino's franchisees are interchangeable with other items available on the market.

Plaintiffs contend that they face information and switching costs that "lock them in" to their position as Domino's franchisees, making it economically impracticable for them to abandon the Domino's system and enter a different line of business. They argue that under Kodak, the fact that they are "locked in" supports their claim that an "aftermarket" for 
INNOVATION AND COMPETITION POLICY

Hovenkamp
Chap. 2, Page 58

Jan., 2013

Domino's-approved supplies is a relevant market for antitrust purposes. We believe plaintiffs misread Kodak.

The defendants in Kodak argued that there was no relevant market in Kodak repair parts, even if they were unique and non-interchangeable with other repair parts, because of cross-elasticity of demand between parts prices and copier sales. If the price of parts were raised too high, defendants contended, it would decrease demand for copiers. The Court held that whether there was cross-elasticity of demand between parts and copiers was, in this case, a factual question that could not be determined as a matter of law. The Court reached this conclusion because switching and information costs arise when one purchases an expensive piece of equipment like a copier. In some circumstances, these costs might create an economic lock-in that could reduce or eliminate the cross-elasticity of demand between copiers and the repair parts for those copiers.

Kodak, we believe, held that a plaintiff's proposed relevant market in a unique and non-interchangeable derivative product or service cannot be defeated on summary judgment by a defendant's assertion that the proposed derivative market is cross-elastic with the primary market, if there is a reasonable possibility that the defendant's assertion about cross-elasticity is factually incorrect. But Kodak does not hold that the existence of information and switching costs alone, such as those faced by the Domino's franchisees, renders an otherwise invalid relevant market valid. In Kodak, the repair parts and service were unique and there was a question of fact about cross-elasticity. Judgment as a matter of law was therefore inappropriate. Here, it is uncontroverted that Domino's approved supplies and ingredients are fully interchangeable in all relevant respects with other pizza supplies outside the proposed relevant market. For this reason, dismissal of the plaintiffs' claim as a matter of law is appropriate.

Kodak is distinguishable from the present appeal in other important respects. The Kodak case arose out of concerns about unilateral changes in Kodak's parts and repairs policies. When the copiers were first sold, Kodak relied on purchasers to obtain service from independent service providers. Later, it chose to use its power over the market in unique replacement parts to squeeze the independent service providers out of the repair market and to force copier purchasers to obtain service directly from Kodak, at higher cost. Because this change in policy was not foreseen at the time of sale, buyers had no ability to calculate these higher costs at the time of purchase and incorporate them into their purchase decision. In contrast, plaintiffs 
here knew that Domino's Pizza retained significant power over their ability to purchase cheaper supplies from alternative sources because that authority was spelled out in detail in section 12.2 of the standard franchise agreement. Unlike the plaintiffs in Kodak, the Domino's franchisees could assess the potential costs and economic risks at the time they signed the franchise agreement. The franchise transaction between Domino's Pizza, Inc. and plaintiffs was subjected to competition at the pre-contract stage. That cannot be said of the conduct challenged in Kodak because it was not authorized by contract terms disclosed at the time of the original transaction. Kodak's sale of its product involved no contractual framework for continuing relations with the purchaser. But a franchise agreement regulating supplies, inspections, and quality standards structures an ongoing relationship between franchisor and franchisee designed to maintain good will. These differences between the Kodak transaction and franchise transactions are compelling....

Were we to accept plaintiffs' relevant market, virtually all franchise tying agreements requiring the franchisee to purchase inputs such as ingredients and supplies from the franchisor would violate antitrust law. Courts and legal commentators have long recognized that franchise tying contracts are an essential and important aspect of the franchise form of business organization because they reduce agency costs and prevent franchisees from freeriding-offering products of sub-standard quality insufficient to maintain the reputational value of the franchise product while benefitting from the quality control efforts of other actors in the franchise system. Franchising is a bedrock of the American economy. More than one third of all dollars spent in retailing transactions in the United States are paid to franchise outlets. We do not believe the antitrust laws were designed to erect a serious barrier to this form of business organization.

The purpose of the Sherman Act "is not to protect businesses from the working of the market; it is to protect the public from the failure of the market." Spectrum Sports, Inc. v. McQuillan, 506 U.S. 447, 458 (1993). Here, plaintiffs' acceptance of a franchise package that included purchase requirements and contractual restrictions is consistent with the existence of a competitive market in which franchises are valued, in part, according to the terms of the proposed franchise agreement and the availability of alternative franchise opportunities. Plaintiffs need not have become Domino's franchisees. If the contractual restrictions in section 12.2 of the general franchise agreement were viewed as overly burdensome or risky at the time they were proposed, plaintiffs could have purchased a different 
form of restaurant, or made some alternative investment. They chose not to do so. Unlike the plaintiffs in Kodak, plaintiffs here must purchase products from Domino's Pizza not because of Domino's market power over a unique product, but because they are bound by contract to do so. If Domino's Pizza, Inc. acted unreasonably when, under the franchise agreement, it restricted plaintiffs' ability to purchase supplies from other sources, plaintiffs' remedy, if any, is in contract, not under the antitrust laws. For these reasons, we agree with the district court that plaintiffs have not pleaded a valid relevant market....

[The court applied the same reasoning in condemning a claim for unlawful tying under $\$ 1$ of the Clayton Act; a dissenting opinion by Judge Lay is omitted.]

\section{NOTES AND QUESTIONS}

Contract lock-in. As courts began to recognize that the legal monopolies created by patents and trademarks don't necessarily amount to economic monopolies, dissatisfied franchisees needed a "new angle" from which to allege illegal tying. Roger D. BLAIR \& Francine LAFONTAINE, THE ECONOMICS OF FRANCHISING 150, 152 (2005). The "lock-in" theory that sprang out of Eastman Kodak appeared to offer franchisees a way to show that franchisors had market power. Id. at 152. But the Supreme Court decided Eastman Kodak in 1992, and despite nearly twenty years and millions of dollars spent litigating "lock-in" claims, "not a single decision has correctly found market power based on Kodak-style lock-in." HERBERT HovenKamp, Federal Antitrust Policy: The LAW of COMPETITION AND ITS PRACTICE $\S 3.3 \mathrm{a} 2$ (4th ed. 2011).

The lock-in problem works like this: While Chrysler competes with Chevy, Ford, Toyota, and a slew of other automobile manufacturers, many of the repair parts for Chryslers are unique. So people who buy Chryslers are "locked in" to Chrysler repair parts. The issue, however, is whether the lock-in enables Chrysler to take advantage of its automobile owners, and if any such advantage amounts to 'monopoly."' Usually it does not. For instance, if Chrysler jacked up repair-part prices for its locked-in Chrysler owners, it would soon find itself out of business-word of the upcharges would spread, and people would very quickly stop buying Chryslers. But in Kodak, the Supreme Court found that high information and switching costs could enable firms to lock in consumers: 
For the service-market price to affect equipment demand, consumers must inform themselves of the total cost of the "package"-equipment, service, and parts-at the time of purchase; that is, consumers must engage in accurate lifecycle pricing. Lifecycle pricing of complex, durable equipment is difficult and costly. ...

A second factor undermining Kodak's claim that supracompetitive prices in the service market lead to ruinous losses in equipment sales is the cost to current owners of switching to a different product. If the cost of switching is high, consumers who already have purchased the equipment, and are thus "locked in," will tolerate some level of service-price increases before changing equipment brands. Under this scenario, a seller profitably could maintain supracompetitive prices in the aftermarket if the switching costs were high relative to the increase in service prices, and the number of locked-in customers were high relative to the number of new purchasers.

Eastman Kodak Co. v. Image Tech. Servs., Inc., 504 U.S. 451, 473, 476 (1992) (citations and footnotes omitted).

Plaintiffs in recent franchise-tying case-including Queen City-have repeatedly claimed to be victims of asymmetric information. Blair \& Lafontaine, supra, at 162 . But this is a tough sell, as state and federal law require franchisors to disclose such information as what supplies franchisees must purchase and whether they must buy them from designated suppliers, as well as information about the expected costs of supplies.

The switching-costs argument does no better. While the relatively higher upfront costs of licensing a franchise might suggest that franchisees are "every bit as locked in ... as a Kodak copier owner is to Kodak repair parts," there is a crucial difference: unlike Kodak copier owners, who own a "durable good with rapidly declining resale value," franchisees "have a revenue-generating asset that has a significant resale value." Id. at 161-62. Dissatisfied franchisees can sell their franchises. Id. Switching costs may therefore pose less of a problem to franchisees, suggesting that lock-in theory is inappropriate in the usual franchise-tying case.

Finally, as you saw in Queen City, courts are extremely unwilling to limit the market-power question to the four corners of the franchise 
contract. In Queen City, the Third Circuit drew a line between "precontract" and "post-contract" market power. While the court acknowledged that post-contract Domino's could require the plaintiffs to buy its pizza dough at above-market prices, it held that this " "power' to 'force' plaintiffs to purchase the alleged tying product stems not from [market power] but from plaintiffs' contractual agreement to purchase the tying product." Queen City, 124 F.3d at 443. If the plaintiffs did not like Domino's terms, they could have picked another franchise. Furthermore, Domino's terms were spelled out clearly in the franchising agreement, and the plaintiffs knew about it when they signed it. Under these circumstances, there could be no "lock-in," could there?

\section{UNITED STATES V. LOEW'S, INC.}

\section{U.S. 38 (1962)}

Mr. Justice GOLDBERG delivered the opinion of the Court.

These consolidated appeals present as a key question the validity under $\S 1$ of the Sherman Act of block booking of copyrighted feature motion pictures for television exhibition. We hold that the tying agreements here are illegal and in violation of the Act.

The United States brought separate civil antitrust actions in the Southern District of New York in 1957 against six major distributors of pre1948 copyrighted motion picture feature films for television exhibition, alleging that each defendant had engaged in block booking in violation of $\S$ 1 of the Sherman Act. The complaints asserted that the defendants had, in selling to television stations, conditioned the license or sale of one or more feature films upon the acceptance by the station of a package or block containing one or more unwanted or inferior films. No combination or conspiracy among the distributors was alleged; nor was any monopolization or attempt to monopolize under $\S 2$ of the Sherman Act averred. The sole claim of illegality rested on the manner in which each defendant had marketed its product. The successful pressure applied to television station customers to accept inferior films along with desirable pictures was the gravamen of the complaint.

... [T] he several defendants have each, from time to time and to the extent set forth in the specific findings of fact, licensed or offered to license one or more feature films to television stations on condition that the 
licensee also license one or more other such feature films, and have, from time to time and to the extent set forth in the specific findings of fact, refused, expressly or impliedly, to license feature films to television stations unless one or more other such feature films were accepted by the licensee.'

The [trial] judge recognized that there was keen competition between the defendant distributors, and therefore rested his conclusion solely on the individual behavior of each in engaging in block booking. In reaching his decision he carefully considered the evidence relating to each of the 68 licensing agreements that the Government had contended involved block booking. He concluded that only 25 of the contracts were illegally entered into. Nine of these belonged to defendant C \& C Super Corp., which had an admitted policy of insisting on block booking that it sought to justify on special grounds.

Of the others, defendant Loew's, Incorporated, had in two negotiations that resulted in licensing agreements declined to furnish stations KWTV of Oklahoma City and WBRE of Wilkes-Barre with individual film prices and had refused their requests for permission to select among the films in the groups. Loew's exacted from KWTV a contract for the entire Loew's library of 723 films, involving payments of $\$ 314,725.20$. The WBRE agreement was for a block of 100 films, payments to total $\$ 15,000$.

Defendant Screen Gems, Inc., was also found to have block booked two contracts, both with WTOP of Washington, D.C., one calling for a package of 26 films and payments of $\$ 20,800$ and the other for 52 films and payments of $\$ 40,000$. The judge accepted the testimony of station officials that they had requested the right to select films and that their requests were refused....

The court entered separate final judgments against the defendants, wherein each was enjoined from

(A) Conditioning or tying, or attempting to condition or tie, the purchase or license of the right to exhibit any feature film over any television station upon the purchase or license of any other film;

(B) Conditioning the purchase or license of the right to exhibit any feature film over any television station upon the purchase or 
INNOVATION AND COMPETITION POLICY

Hovenkamp
Chap. 2, Page 64

Jan., 2013

license for exhibition over any other television station of that feature film, or any other film;

(C) Entering into any agreement to sell or license the right to exhibit any feature film over any television station in which the differential between the price or fee for such feature film when sold or licensed alone and the price or fee for the same film when sold or licensed with one or more other film (sic) has the effect of conditioning the sale or license of such film upon the sale or license of one or more other films.'

This case raises the recurring question of whether specific tying arrangements violate $\S 1$ of the Sherman Act. This Court has recognized that '(t)ying agreements serve hardly any purpose beyond the suppression of competition,' Standard Oil Co. of California v. United States, 337 U.S. 293, 305-306. They are an object of anti-trust concern for two reasons-they may force buyers into giving up the purchase of substitutes for the tied product, see Times-Picayune Pub. Co. v. United States, 345 U.S. 594, 605, and they may destroy the free access of competing suppliers of the tied product to the consuming market, see International Salt Co. v. United States, 332 U.S. 392, 396. A tie-in contract may have one or both of these undesirable effects when the seller, by virtue of his position in the market for the tying product, has economic leverage sufficient to induce his customers to take the tied product along with the tying item. The standard of illegality is that the seller must have 'sufficient economic power with respect to the tying product to appreciably restrain free competition in the market for the tied product $* * *$.' Northern Pacific R. Co. v. United States, 356 U.S. 1, 6. Market dominance-some power to control price and to exclude competition-is by no means the only test of whether the seller has the requisite economic power. Even absent a showing of market dominance, the crucial economic power may be inferred from the tying product's desirability to consumers or from uniqueness in its attributes.

The requisite economic power is presumed when the tying product is patented or copyrighted, International Salt Co. v. United States, 332 U.S. 392; United States v. Paramount Pictures, Inc., 334 U.S. 131. This principle grew out of a long line of patent cases which had eventuated in the doctrine that a patentee who utilized tying arrangements would be denied all relief against infringements of his patent. Motion Picture Patents Co. v. Universal Film Mfg. Co., 243 U.S. 502; Carbice Corp. v. American Patents Dev. Corp., 283 U.S. 27. These cases reflect a hostility to use of the statutorily 
INNOVATION AND COMPETITION POLICY

Hovenkamp
Chap. 2, Page 65

Jan, 2013

granted patent monopoly to extend the patentee's economic control to unpatented products. The patentee is protected as to his invention, but may not use his patent rights to exact tribute for other articles.

Since one of the objectives of the patent laws is to reward uniqueness, the principle of these cases was carried over into antitrust law on the theory that the existence of a valid patent on the tying product, without more, establishes a distinctiveness sufficient to conclude that any tying arrangement involving the patented product would have anticompetitive consequences. In United States v. Paramount Pictures, Inc., 334 U.S. 131, 156-159 [1948], the principle of the patent cases was applied to copyrighted feature films which had been block booked into movie theaters. The Court reasoned that

'The copyright law, like the patent statutes, makes reward to the owner a secondary consideration. In Fox Film Corp. v. Doyal, 286 U.S. 123, Chief Justice Hughes spoke as follows respecting the copyright monopoly granted by Congress. 'The sole interest of the United States and the primary object in conferring the monopoly lie in the general benefits derived by the public from the labors of authors.' It is said that reward to the author or artist serves to induce release to the public of the products of his creative genius. But the reward does not serve its public purpose if it is not related to the quality of the copyright. Where a high quality film greatly desired is licensed only if an inferior one is taken, the latter borrows quality from the former and strengthens its monopoly by drawing on the other. The practice tends to equalize rather than differentiate the reward for the individual copyrights. Even where all the films included in the package are of equal quality, the requirement that all be taken if one is desired increases the market for some. Each stands not on its own footing but in whole or in part on the appeal which another film may have. As the District Court said, the result is to add to the monopoly of the copyright in violation of the principle of the patent cases involving tying clauses.' 334 U.S., at 158.

Appellants attempt to distinguish the Paramount decision in its relation to the present facts: the block booked sale of copyrighted feature films to exhibitors in a new medium-television. Not challenging the District Court's finding that they did engage in block booking, they contend that the uniqueness attributable to a copyrighted feature film, though relevant in the movie-theater context, is lost when the film is being sold for television use. 
INNOVATION AND COMPETITION POLICY

Hovenkamp
Chap. 2, Page 66

Jan., 2013

Feature films, they point out, constitute less than $8 \%$ of television programming, and they assert that films are 'reasonably interchangeable' with other types of programming material and with other feature films as well. Thus they argue that their behavior is not to be judged by the principle of the patent cases, as applied to copyrighted materials in Paramount Pictures, but by the general principles which govern the validity of tying arrangements of nonpatented products, e.g., Northern Pacific R. Co. v. United States, 356 U.S. 1, 6. They say that the Government's proof did not establish their 'sufficient economic power' in the sense contemplated for nonpatented products.

Appellants cannot escape the applicability of Paramount Pictures. A copyrighted feature film does not lose its legal or economic uniqueness because it is shown on a television rather than a movie screen.

The district judge found that each copyrighted film block booked by appellants for television use 'was in itself a unique product'; that feature films 'varied in theme, in artistic performance, in stars, in audience appeal, etc.,' and were not fungible; and that since each defendant by reason of its copyright had a 'monopolistic' position as to each tying product, 'sufficient economic power' to impose an appreciable restraint on free competition in the tied product was present, as demanded by the Northern Pacific decision. We agree. These findings of the district judge, supported by the record, confirm the presumption of uniqueness resulting from the existence of the copyright itself.

Moreover, there can be no question in this case of the adverse effects on free competition resulting from appellants' illegal block booking contracts. Television stations forced by appellants to take unwanted films were denied access to films marketed by other distributors who, in turn, were foreclosed from selling to the stations. ... These anti-competitive consequences are an apt illustration of the reasons underlying our recognition that the mere presence of competing substitutes for the tying product, here taking the form of other programming material as well as other feature films, is insufficient to destroy the legal, and indeed the economic, distinctiveness of the copyrighted product. Standard Oil Co. of California v. United States, 337 U.S. 293, 307; Times-Picayune Pub. Co. v. United States, 345 U.S. 594, 611 and n. 30. By the same token, the distinctiveness of the copyrighted tied product is not inconsistent with the fact of competition, in the form of other programming material and other films, which is suppressed by the tying arrangements. 
It is therefore clear that the tying arrangements here both by their 'inherent nature' and by their 'effect' injuriously restrained trade. United States v. American Tobacco Co., 221 U.S. 106, 179. Accommodation between the statutorily dispensed monopoly in the combination of contents in the patented or copyrighted product and the statutory principles of free competition demands that extension of the patent or copyright monopoly by the use of tying agreements be strictly confined. There may be rare circumstances in which the doctrine we have enunciated under $\S 1$ of the Sherman Act prohibiting tying arrangements involving patented or copyrighted tying products is inapplicable. However, we find it difficult to conceive of such a case, and the present case is clearly not one....

The United States contends that the relief afforded by the final judgments is inadequate and that to be adequate it must also: (1) require the defendants to price the films individually and offer them on a picture-bypicture basis; (2) prohibit noncost-justified differentials in price between a film when sold individually and when sold as part of a package; (3) proscribe 'temporary' refusals by a distributor to deal on less than a block basis while he is negotiating with a competing television station for a package sale.

Under the final judgments entered by the court, a distributor would be free to offer films in a package initially, without stating individual prices. If, however, he delayed at all in producing individual prices upon request, he would subject himself to a possible contempt sanction. The Government's first request would prevent this 'first bite' possibility, forcing the offer of the films on an individual basis at the outset (but, as we view it, not precluding a simultaneous package offer, United States v. Paramount Pictures, Inc., supra, 334 U.S., at 159....

The final judgments as entered only prohibit a price differential between a film offered individually and as part of a package which 'has the effect of conditioning the sale or license of such film upon the sale or license of one or more other films.' The Government contends that this provision appearing by itself is too vague and will lead to unnecessary litigation. Differentials unjustified by cost savings may already be prohibited under the decree as it now appears. Nevertheless, the addition of a specific provision to prevent such differentials will prevent uncertainty in the operation of the decree. To ensure that litigation over the scope and application of the decrees is not left until a contempt proceeding is brought, 
the second requested modification should be added. The Government, however, seeks to make distribution costs the only saving which can legitimately be the basis of a discount. We would not so limit the relevant cost justifications. To prevent definitional arguments, and to ensure that all proper bases of quantity discount may be used, the modification should be worded in terms of allowing all legitimate cost justifications.

The Government's third request is, like the first, designed to prevent distributors from subjecting prospective purchasers to a 'run-around' on the purchase of individual films. No doubt temporary refusal to sell in broken lots to one customer while negotiating to sell the entire block to another is a proper business practice, viewed in vacuo, but we think that if permitted here it may tend to force some stations into buying pre-set packages to forestall a competitor's getting the entire group. In recognition of this the Government seeks a blanket prohibition against all temporary refusals to deal. We agree in the main, except that the modification proposed by the Government fails to give full recognition to that part of this Court's holding in Paramount Pictures which said,

'We do not suggest that films may not be sold in blocks or groups, when there is no requirement, express or implied, for the purchase of more than one film. All we hold to be illegal is a refusal to license one or more copyrights unless another copyright is accepted.'

The modifications we have specified will bring about a greater precision in the operation of the decrees. We have concluded that they will properly protect the interest of the Government in guarding against violations and the interest of the defendants in seeking in good faith to comply.

The judgments are vacated and the causes are remanded to the District Court for further proceedings in conformity with this opinion.

Vacated and remanded.

\section{NOTES AND QUESTIONS}

1. Does block booking necessarily decrease consumer welfare? What if different costumers do not value separate products the same? Suppose that Loew's values movie $A$ at $\$ 1,000$ and movie $B$ at $\$ 10,000$. Suppose further that $\mathrm{C} \& \mathrm{C}$ values movie $\mathrm{A}$ at $\$ 8,000$ and movie $\mathrm{B}$ at $\$ 1,200$. Does 
requiring the rights-holder to offer the movies individually rather than in a block always increase consumer welfare? See Erik Hovenkamp \& Herbert Hovenkamp, Tying Arrangements and Antitrust Harm, 52 ARIZ. L. REV. 925, 956-59 (2010).

2. Are there other explanations for why a firm would want to sell its products in blocks? If a firm charges different customers different prices, the customers may perceive this discrepancy as unfair, even though the customers value the same product differently. See Barak Y. Orbach, Antitrust and Pricing in the Motion Picture Industry, 21 YALE J. REG. 317, 353-55 (2004). Another reason a firm may want to block book is to prevent oversearching. By not allowing a customer to pick from individual films, the rights-holders do not have to spend the resources to price each film individually. See F. Andrew Hanssen, The Block Booking of Films Reexamined, 43 J.L. \& ECON. 395, 398-99. Can you think of any other reasons a firm would engage in block booking? See generally id.; Bruce H. Kobayashi, Does Economics Provide a Reliable Guide to Regulating Commodity Bundling by Firms?A Survey of the Economic Literature, $1 \mathrm{~J}$. COMPETITION L. \& ECON. 707, 714-27 (2005).

3. Note that the Court's decree permitted "cost justified" bundling. That is, if the costs of licensing a block of films is lower than of licensing each film separately, the defendant could pass on the cost savings but no more. Of course, if cost savings fully explained the blocks, then the decree effectively permitting blocking in any event.

\section{UNITED STATES v. MICROSOFT CORP. 253 F.3d 34 (D.C. Cir.) cert. denied, 534 U.S. 952 (2001)}

Per Curiam

The action against Microsoft arose pursuant to a complaint filed by the United States and separate complaints filed by individual States. The District Court determined that Microsoft had maintained a monopoly in the market for Intel-compatible PC operating systems in violation of $\S 2$; attempted to gain a monopoly in the market for internet browsers in violation of $\S 2$; and illegally tied two purportedly separate products, Windows and Internet Explorer ("IE"), in violation of $\S 1$. United States v. Microsoft Corp., 87 F.Supp.2d 30 (D.D.C.2000) ("Conclusions of Law"). The District Court then found that the same facts that established liability 
INNOVATION AND COMPETITION POLICY

Hovenkamp
Chap. 2, Page 70

Jan., 2013

under $\S \S 1$ and 2 of the Sherman Act mandated findings of liability under analogous state law antitrust provisions....

As a general rule, courts are properly very skeptical about claims that competition has been harmed by a dominant firm's product design changes. See, e.g., Foremost Pro Color, Inc. v. Eastman Kodak Co., 703 F.2d 534, 544-45 (9th Cir.1983). In a competitive market, firms routinely innovate in the hope of appealing to consumers, sometimes in the process making their products incompatible with those of rivals; the imposition of liability when a monopolist does the same thing will inevitably deter a certain amount of innovation. This is all the more true in a market, such as this one, in which the product itself is rapidly changing. Judicial deference to product innovation, however, does not mean that a monopolist's product design decisions are per se lawful. See Foremost Pro Color, 703 F.2d at 545; see also Cal. Computer Prods., 613 F.2d at 739, 744; In re IBM Peripheral EDP Devices Antitrust Litig., 481 F.Supp. 965, 1007-08 (N.D.Cal.1979).

[Commingling of Code, Under $\S 2$ of the Sherman Act]

... [T] $]$ he District Court condemned Microsoft's decision to bind IE to Windows 98 "by placing code specific to Web browsing in the same files as code that provided operating system functions." Putting code supplying browsing functionality into a file with code supplying operating system functionality "ensure[s] that the deletion of any file containing browsingspecific routines would also delete vital operating system routines and thus cripple Windows...." [P] $]$ eventing an OEM from removing IE deters it from installing a second browser because doing so increases the OEM's product testing and support costs; by contrast, had OEMs been able to remove IE, they might have chosen to pre-install [Netscape] Navigator alone.****

[T] Windows 98 "by placing code specific to Web browsing in the same files as code that provided operating system functions." Putting code supplying browsing functionality into a file with code supplying operating system functionality "ensure[s] that the deletion of any file containing browsingspecific routines would also delete vital operating system routines and thus cripple Windows...." As noted above, preventing an OEM from removing IE deters it from installing a second browser because doing so increases the OEM's product testing and support costs; by contrast, had OEMs been able to remove IE, they might have chosen to pre-install Navigator alone. 
INNOVATION AND COMPETITION POLICY

Hovenkamp
Chap. 2, Page 71

Jan, 2013

Microsoft denies, as a factual matter, that it commingled browsing and non-browsing code, and it maintains the District Court's findings to the contrary are clearly erroneous. According to Microsoft, its expert "testified without contradiction that ' $[\mathrm{t}]$ he very same code in Windows 98 that provides Web browsing functionality' also performs essential operating system functions-not code in the same files, but the very same software code."

Microsoft's expert did not testify to that effect "without contradiction," however. A Government expert, Glenn Weadock, testified that Microsoft "design [ed] [IE] so that some of the code that it uses coresides in the same library files as other code needed for Windows." Another Government expert likewise testified that one library file, SHDOCVW.DLL, "is really a bundle of separate functions. It contains some functions that have to do specifically with Web browsing, and it contains some general user interface functions as well." One of Microsoft's own documents suggests as much. See Plaintiffs' Proposed Findings of Fact II 131.2.vii (citing GX 1686 (under seal) (Microsoft document indicating some functions in SHDOCVW.DLL can be described as "IE only," others can be described as "shell only" and still others can be described as providing both "IE" and "shell" functions)).

In view of the contradictory testimony in the record, some of which supports the District Court's finding that Microsoft commingled browsing and non-browsing code, we cannot conclude that the finding was clearly erroneous. See Anderson v. City of Bessemer City, 470 U.S. 564, 573-74 (1985) ("If the district court's account of the evidence is plausible in light of the record viewed in its entirety, the court of appeals may not reverse it even though convinced that had it been sitting as the trier of fact, it would have weighed the evidence differently."). Accordingly, we reject Microsoft's argument that we should vacate Finding of Fact 159 as it relates to the commingling of code, and we conclude that such commingling has an anticompetitive effect; as noted above, the commingling deters OEMs from pre-installing rival browsers, thereby reducing the rivals' usage share and, hence, developers' interest in rivals' APIs as an alternative to the API set exposed by Microsoft's operating system.

Microsoft's justifications for integration 
INNOVATION AND COMPETITION POLICY

Hovenkamp
Chap. 2, Page 72

Jan., 2013

... Although Microsoft does make some general claims regarding the benefits of integrating the browser and the operating system, see, e.g., Direct Testimony of James Allchin II 94,reprinted in 5 J.A. at 3321 ("Our vision of deeper levels of technical integration is highly efficient and provides substantial benefits to customers and developers."), it neither specifies nor substantiates those claims. Nor does it argue that either excluding IE from the Add/Remove Programs utility or commingling code achieves any integrative benefit. Plaintiffs plainly made out a prima facie case of harm to competition in the operating system market by demonstrating that Microsoft's actions increased its browser usage share and thus protected its operating system monopoly from a middleware threat and, for its part, Microsoft failed to meet its burden of showing that its conduct serves a purpose other than protecting its operating system monopoly. Accordingly, we hold that Microsoft's exclusion of IE from the Add/Remove Programs utility and its commingling of browser and operating system code constitute exclusionary conduct, in violation of $\S$ $2 \ldots$

\section{TYING $* * * *$ [Mainly under $\S 1$ of the Sherman Act]}

The District Court concluded that Microsoft's contractual and technological bundling of the IE web browser (the "tied" product) with its Windows operating system ("OS") (the "tying" product) resulted in a tying arrangement that was per se unlawful. We hold that the rule of reason, rather than per se analysis, should govern the legality of tying arrangements involving platform software products....

The key District Court findings are that (1) Microsoft required licensees of Windows 95 and 98 also to license IE as a bundle at a single price, (2) Microsoft refused to allow OEMs to uninstall or remove IE from the Windows desktop, (3) Microsoft designed Windows 98 in a way that withheld from consumers the ability to remove IE by use of the Add/Remove Programs utility, and (4) Microsoft designed Windows 98 to override the user's choice of default web browser in certain circumstances. ... Although the District Court also found that Microsoft commingled operating system-only and browser-only routines in the same library files, it did not include this as a basis for tying liability despite plaintiffs' request that it do so.... 
INNOVATION AND COMPETITION POLICY

Hovenkamp
Chap. 2, Page 73

Jan, 2013

Microsoft does not dispute that it bound Windows and IE in the four ways the District Court cited. Instead it argues that Windows (the tying good) and IE browsers (the tied good) are not "separate products," ...

The first case to give content to the separate-products test was Jefferson Parish, 466 U.S. 2. That case addressed a tying arrangement in which a hospital conditioned surgical care at its facility on the purchase of anesthesiological services from an affiliated medical group. The facts were a challenge for casual separate-products analysis because the tied service anesthesia - was neither intuitively distinct from nor intuitively contained within the tying service - surgical care. A further complication was that, soon after the Court enunciated the per se rule for tying liability in International Salt Co. v. United States, 332 U.S. 392, 396 (1947), and Northern Pacific Railway Co. v. United States, 356 U.S. 1, 5-7 (1958), new economic research began to cast doubt on the assumption, voiced by the Court when it established the rule, that "tying agreements serve hardly any purpose beyond the suppression of competition."

The Jefferson Parish Court resolved the matter in two steps. First, it clarified that "the answer to the question whether one or two products are involved" does not turn "on the functional relation between them. ..." In other words, the mere fact that two items are complements, that "one ... is useless without the other," does not make them a single "product" for purposes of tying law. ... Second, reasoning that the "definitional question [whether two distinguishable products are involved] depends on whether the arrangement may have the type of competitive consequences addressed by the rule [against tying]," the Court decreed that "no tying arrangement can exist unless there is a sufficient demand for the purchase of anesthesiological services separate from hospital services to identify a distinct product market in which it is efficient to offer anesthesiological services separately from hospital service. ..."

To understand the logic behind the Court's consumer demand test, consider first the postulated harms from tying. The core concern is that tying prevents goods from competing directly for consumer choice on their merits, i.e., being selected as a result of "buyers' independent judgment," ... With a tie, a buyer's "freedom to select the best bargain in the second market [could be] impaired by his need to purchase the tying product, and perhaps by an inability to evaluate the true cost of either product. ..." Direct competition on the merits of the tied product is foreclosed when the tying product either is sold only in a bundle with the tied product or, though 
INNOVATION AND COMPETITION POLICY

Hovenkamp
Chap. 2, Page 74

Jan., 2013

offered separately, is sold at a bundled price, so that the buyer pays the same price whether he takes the tied product or not. ...

But not all ties are bad. Bundling obviously saves distribution and consumer transaction costs. 9 Areeda, Antitrust Law II 1703g2 (1991). This is likely to be true, to take some examples from the computer industry, with the integration of math co-processors and memory into microprocessor chips and the inclusion of spell checkers in word processors. ... Indeed, if there were no efficiencies from a tie (including economizing on consumer transaction costs such as the time and effort involved in choice), we would expect distinct consumer demand for each individual component of every good. ...

Before concluding our exegesis of Jefferson Parish's separate-products test, we should clarify two things. First, Jefferson Parish does not endorse a direct inquiry into the efficiencies of a bundle. Rather, it proposes easy-toadminister proxies for net efficiency. In describing the separate-products test we discuss efficiencies only to explain the rationale behind the consumer demand inquiry. ...

Second, the separate-products test is not a one-sided inquiry into the cost savings from a bundle. Although Jefferson Parish acknowledged that prior lower court cases looked at cost-savings to decide separate products, the Court conspicuously did not adopt that approach in its disposition of tying arrangement before it. Instead it chose proxies that balance costs savings against reduction in consumer choice.

... [T]here is merit to Microsoft's broader argument that Jefferson Parish's consumer demand test would "chill innovation to the detriment of consumers by preventing firms from integrating into their products new functionality previously provided by standalone products - and hence, by definition, subject to separate consumer demand."

In light of the monopoly maintenance section, obviously, we do not find that Microsoft's integration is welfare-enhancing or that it should be absolved of tying liability. Rather, we heed Microsoft's warning that the separate-products element of the per se rule may not give newly integrated products a fair shake.

The Supreme Court has warned that " [i]t is only after considerable experience with certain business relationships that courts classify them as 
INNOVATION AND COMPETITION POLICY

Hovenkamp
Chap. 2, Page 75

Jan, 2013

per se violations. ..." Broadcast Music, 441 U.S. at 9. ... Yet the sort of tying arrangement attacked here is unlike any the Supreme Court has considered. ...

In none of [the earlier Supreme Court] cases was the tied good physically and technologically integrated with the tying good. Nor did the defendants ever argue that their tie improved the value of the tying product to users and to makers of complementary goods. In those cases where the defendant claimed that use of the tied good made the tying good more valuable to users, the Court ruled that the same result could be achieved via quality standards for substitutes of the tied good. ...Here Microsoft argues that IE and Windows are an integrated physical product and that the bundling of IE APIs with Windows makes the latter a better applications platform for third-party software. It is unclear how the benefits from IE APIs could be achieved by quality standards for different browser manufacturers. We do not pass judgment on Microsoft's claims regarding the benefits from integration of its APIs. We merely note that these and other novel, purported efficiencies suggest that judicial "experience" provides little basis for believing that, "because of their pernicious effect on competition and lack of any redeeming virtue," a software firm's decisions to sell multiple functionalities as a package should be "conclusively presumed to be unreasonable and therefore illegal without elaborate inquiry as to the precise harm they have caused or the business excuse for their use." ...

...The failure of the separate-products test to screen out certain cases of productive integration is particularly troubling in platform software markets such as that in which the defendant competes. Not only is integration common in such markets, but it is common among firms without market power. We have already reviewed evidence that nearly all competitive OS vendors also bundle browsers. Moreover, plaintiffs do not dispute that OS vendors can and do incorporate basic internet plumbing and other useful functionality into their OSs....

... [B]ecause of the pervasively innovative character of platform software markets, tying in such markets may produce efficiencies that courts have not previously encountered and thus the Supreme Court had not factored into the per se rule as originally conceived. For example, the bundling of a browser with OSs enables an independent software developer to count on the presence of the browser's APIs, if any, on consumers' machines and thus to omit them from its own package. ... 
INNOVATION AND COMPETITION POLICY

Hovenkamp
Chap. 2, Page 76

Jan., 2013

We do not have enough empirical evidence regarding the effect of Microsoft's practice on the amount of consumer surplus created or consumer choice foreclosed by the integration of added functionality into platform software to exercise sensible judgment regarding that entire class of behavior.

Our judgment regarding the comparative merits of the per se rule and the rule of reason is confined to the tying arrangement before us, where the tying product is software whose major purpose is to serve as a platform for third-party applications and the tied product is complementary software functionality. While our reasoning may at times appear to have broader force, we do not have the confidence to speak to facts outside the record. ...

Should plaintiffs choose to pursue a tying claim under the rule of reason, we note the following for the benefit of the trial court:

...[O]n remand, plaintiffs must show that Microsoft's conduct unreasonably restrained competition. Meeting that burden "involves an inquiry into the actual effect" of Microsoft's conduct on competition in the tied good market, Jefferson Parish, 466 U.S. at 29, the putative market for browsers. [However, given its loss on market-power questions of the browser-attempt claim the court forbad the government from relying on any theory that required the definition of a browser market and a showing of high entry barriers there - ed.]

\section{NOTES AND QUESTIONS}

1. The Microsoft decision produced an enormous variety of commentary. See, e.g., Andrew Chin, Decoding Microsoft: A First Principles Approach, 40 WAKE FOREST L. REV. 1, 137-38 (2005) ("[T]he Microsoft tying claim satisfied all of the generally required elements of a per se illegal tying arrangement. ... . [T] he plaintiffs would still have been able to prevail on their tying claim ... where the residual rule of reason was the only available basis for liability."); Keith N. Hylton \& Michael Salinger, Tying Law and Policy: A Decision-Theoretic Approach, 69 AnTITRUst L.J. 469, 520 (2001) ("[W]e see no reason to treat software bundling as less deserving of the non-interventionist standard than other types of product integration."). For an example of support, see Harry First \& Andrew I. Gavil, Re-Framing Windows: The Durable Meaning of the Microsoft Antitrust Litigation, 2006 UTAH L.REV. (2006)(noting that “. . . opponents 
INNOVATION AND COMPETITION POLICY

Hovenkamp
Chap. 2, Page 77

Jan, 2013

of the government's prosecution of Microsoft . . . [charged that] antitrust enforcement was a crude and slow tool, ill-suited for the fast-paced and changing markets of the information age . . . [but that] [t]oday, more than a decade after the Justice Department reached its first consent decree with Microsoft, Microsoft's share of the Intel-compatible PC operating system market remains above ninety percent," and that "Excess caution by enforcers and courts ... inherently favors the incumbent at the expense of competition.”).

2. The D.C. Circuit vacated the district court's conclusion that the per se rule governed Microsoft's contractual and technological tying of Internet Explorer to its Windows operating system. Rather, the court concluded, the rule of reason should be applied to a tie in which the tying product is a software computer platform and the tied product is an application. The court reached this conclusion, not by purporting to overrule the Supreme Court's highly generalized per se rule governing tying arrangements, but rather by stressing the novelty of the arrangement before it given that only a few previous cases had involved ties of computer software. This suggestion that the per se tying rule is "market specific" is unprecedented and seems quite inconsistent with Supreme Court precedent, which has applied the per se rule to ties in new markets by generalizing from older cases that arose in different markets. Indeed, it is inconsistent with the jurisprudence of the per se rule generally, which is not product specific, although the nature of the product or service in question may affect the disposition of particular issues.

In creating this market specific rule, the court took rather extreme liberties with this statement from the Supreme Court's Jefferson Parish decision: "[i]t is far too late in the history of our antitrust jurisprudence to question the proposition that certain tying arrangements pose an unacceptable risk of stifling competition and therefore are unreasonable 'per se." The D.C. Circuit italicized the word "certain" in the Jefferson Parish statement -- as if what the Supreme Court had meant to say was that some ties required per se treatment but others required rule of reason treatment and it was up to the lower courts to decide which was which. While that is true, the lower court's liberty to reject the per se rule had never been related to the particular market in which tying occurred. Rather, The Supreme Court had used the word "certain" to indicate that the per se rule for tying applied only where its doctrinal requirements were established. That is, a court might conclude that the defendant lacked tying product power, and thus that its tie was not one of those arrangements posing an unacceptable 
risk of stifling competition. The lower courts were not given a warrant to slice and dice the world of tying arrangements depending on the type or product or service that was at issue.

\section{ILLINOIS TOOL WORKS, INC. V. INDEPENDENT INK, INC. 547 U.S. 28 (2006)}

JUSTICE STEVENS delivered the opinion of the Court.

In Jefferson Parish Hospital Dist. No. 2 v. Hyde, 466 U.S. 2 (1984), we repeated the well-settled proposition that "if the Government has granted the seller a patent or similar monopoly over a product, it is fair to presume that the inability to buy the product elsewhere gives the seller market power." This presumption of market power, applicable in the antitrust context when a seller conditions its sale of a patented product (the "tying" product) on the purchase of a second product (the "tied" product), has its foundation in the judicially created patent misuse doctrine. See United States v. Loew's Inc., 371 U.S. 38, 46 (1962). In 1988, Congress substantially undermined that foundation, amending the Patent Act to eliminate the market power presumption in patent misuse cases. See 102 Stat. 4674 , codified at 35 U.S.C. $\S 271(d)$. The question presented to us today is whether the presumption of market power in a patented product should survive as a matter of antitrust law despite its demise in patent law. We conclude that the mere fact that a tying product is patented does not support such a presumption.

Petitioners, Trident, Inc., and its parent, Illinois Tool Works Inc., manufacture and market printing systems that include three relevant components: (1) a patented piezoelectric impulse ink jet printhead; (2) a patented ink container, consisting of a bottle and valved cap, which attaches to the printhead; and (3) specially designed, but unpatented, ink. Petitioners sell their systems to original equipment manufacturers (OEMs) who are licensed to incorporate the printheads and containers into printers that are in turn sold to companies for use in printing barcodes on cartons and packaging materials. The OEMs agree that they will purchase their ink exclusively from petitioners, and that neither they nor their customers will refill the patented containers with ink of any kind.

Respondent, Independent Ink, Inc., has developed an ink with the same chemical composition as the ink sold by petitioners. After an infringement action brought by Trident against Independent was dismissed for lack of 
INNOVATION AND COMPETITION POLICY

Hovenkamp
Chap. 2, Page 79

Jan, 2013

personal jurisdiction, Independent filed suit against Trident seeking a judgment of noninfringement and invalidity of Trident's patents. In an amended complaint, it alleged that petitioners are engaged in illegal tying and monopolization in violation of $\S \S 1$ and 2 of the Sherman Act. 15 U.S.C. $\S \S 1,2$.

After discovery, the District Court granted petitioners' motion for summary judgment on the Sherman Act claims. It rejected respondent's submission that petitioners "necessarily have market power in the market for the tying product as a matter of law solely by virtue of the patent on their printhead system, thereby rendering [the] tying arrangements per se violations of the antitrust laws." Finding that respondent had submitted no affirmative evidence defining the relevant market or establishing petitioners' power within it, the court concluded that respondent could not prevail on either antitrust claim. The parties settled their other claims, and respondent appealed.

After a careful review of the "long history of Supreme Court consideration of the legality of tying arrangements," 396 F.3d 1342, 1346 (2005), the Court of Appeals for the Federal Circuit reversed the District Court's decision as to respondent's $\S 1$ claim. Placing special reliance on our decisions in International Salt Co. v. United States, 332 U.S. 392 (1947), and Loew's, 371 U.S. 38, as well as our Jefferson Parish dictum, and after taking note of the academic criticism of those cases, it concluded that the "fundamental error" in petitioners' submission was its disregard of "the duty of a court of appeals to follow the precedents of the Supreme Court until the Court itself chooses to expressly overrule them." 396 F.3d, at 1351. We granted certiorari to undertake a fresh examination of the history of both the judicial and legislative appraisals of tying arrangements. Our review is informed by extensive scholarly comment and a change in position by the administrative agencies charged with enforcement of the antitrust laws.

American courts first encountered tying arrangements in the course of patent infringement litigation. See, e.g., Heaton-Peninsular Button-Fastener Co. v. Eureka Specialty Co., 77 F. 288 (6th Cir 1896). Such a case came before this Court in Henry v. A.B. Dick Co., 224 U.S. 1 (1912), in which, as in the case we decide today, unpatented ink was the product that was "tied" to the use of a patented product through the use of a licensing agreement. Without commenting on the tying arrangement, the Court held that use of a competitor's ink in violation of a condition of the agreement--that the rotary mimeograph "'may be used only with the stencil, paper, ink and other 
INNOVATION AND COMPETITION POLICY

Hovenkamp
Chap. 2, Page 80

Jan., 2013

supplies made by A.B. Dick Co."'--constituted infringement of the patent on the machine. Chief Justice White dissented, explaining his disagreement with the Court's approval of a practice that he regarded as an "attempt to increase the scope of the monopoly granted by a patent ... which tend[s] to increase monopoly and to burden the public in the exercise of their common rights." Two years later, Congress endorsed Chief Justice White's disapproval of tying arrangements, enacting $\S 3$ of the Clayton Act. See 38 Stat. 731 (applying to "patented or unpatented" products); see also Motion Picture Patents Co. v. Universal Film Mfg. Co., 243 U.S. 502, 517-518 (1917) (explaining that, in light of $\S 3$ of the Clayton Act, A.B. Dick "must be regarded as overruled"). And in this Court's subsequent cases reviewing the legality of tying arrangements we, too, embraced Chief Justice White's disapproval of those arrangements. See, e.g., Standard Oil Co. of Cal. v. United States, 337 U.S. 293, 305-306 (1949); Mercoid Corp. v. MidContinent Investment Co., 320 U.S. 661, 664-665 (1944).

In the years since A.B. Dick, four different rules of law have supported challenges to tying arrangements. They have been condemned as improper extensions of the patent monopoly under the patent misuse doctrine, as unfair methods of competition under $\S 5$ of the Federal Trade Commission Act, 15 U.S.C. $\S 45$, as contracts tending to create a monopoly under $\S 3$ of the Clayton Act, 15 U.S.C. $\S 13 \mathrm{a}$, and as contracts in restraint of trade under $\S 1$ of the Sherman Act. In all of those instances, the justification for the challenge rested on either an assumption or a showing that the defendant's position of power in the market for the tying product was being used to restrain competition in the market for the tied product. As we explained in Jefferson Parish, 466 U.S., at 12, "[o]ur cases have concluded that the essential characteristic of an invalid tying arrangement lies in the seller's exploitation of its control over the tying product to force the buyer into the purchase of a tied product that the buyer either did not want at all, or might have preferred to purchase elsewhere on different terms."

Over the years, however, this Court's strong disapproval of tying arrangements has substantially diminished. Rather than relying on assumptions, in its more recent opinions the Court has required a showing of market power in the tying product. Our early opinions consistently assumed that "[t]ying arrangements serve hardly any purpose beyond the suppression of competition." Standard Oil Co., 337 U.S., at 305-306. In 1962, in Loew's, 371 U.S., at 47-48, the Court relied on this assumption despite evidence of significant competition in the market for the tying product. And as recently as 1969, Justice Black, writing for the majority, 
INNOVATION AND COMPETITION POLICY

Hovenkamp
Chap. 2, Page 81

Jan, 2013

relied on the assumption as support for the proposition "that, at least when certain prerequisites are met, arrangements of this kind are illegal in and of themselves, and no specific showing of unreasonable competitive effect is required." Fortner Enterprises, Inc. v. United States Steel Corp., 394 U.S. 495, 498-499 (Fortner I). Explaining the Court's decision to allow the suit to proceed to trial, he stated that "decisions rejecting the need for proof of truly dominant power over the tying product have all been based on a recognition that because tying arrangements generally serve no legitimate business purpose that cannot be achieved in some less restrictive way, the presence of any appreciable restraint on competition provides a sufficient reason for invalidating the tie."

Reflecting a changing view of tying arrangements, four Justices dissented in Fortner I, arguing that the challenged "tie"--the extension of a \$2 million line of credit on condition that the borrower purchase prefabricated houses from the defendant--might well have served a legitimate purpose. In his opinion, Justice White noted that promotional tieins may provide "uniquely advantageous deals" to purchasers. And Justice Fortas concluded that the arrangement was best characterized as "a sale of a single product with the incidental provision of financing."

The dissenters' view that tying arrangements may well be procompetitive ultimately prevailed; indeed, it did so in the very same lawsuit. After the Court remanded the suit in Fortner I, a bench trial resulted in judgment for the plaintiff, and the case eventually made its way back to this Court. Upon return, we unanimously held that the plaintiff's failure of proof on the issue of market power was fatal to its case--the plaintiff had proved "nothing more than a willingness to provide cheap financing in order to sell expensive houses." United States Steel Corp. v. Fortner Enterprises, Inc., 429 U.S. 610, 622 (1977) (Fortner II).

The assumption that " $[\mathrm{t}]$ ying arrangements serve hardly any purpose beyond the suppression of competition," rejected in Fortner II, has not been endorsed in any opinion since. Instead, it was again rejected just seven years later in Jefferson Parish, where, as in Fortner II, we unanimously reversed a Court of Appeals judgment holding that an alleged tying arrangement constituted a per se violation of $\S 1$ of the Sherman Act. 466 U.S., at 5. Like the product at issue in the Fortner cases, the tying product in Jefferson Parish--hospital services--was unpatented, and our holding again rested on the conclusion that the plaintiff had failed to prove sufficient 
INNOVATION AND COMPETITION POLICY

Hovenkamp
Chap. 2, Page 82

Jan., 2013

power in the tying product market to restrain competition in the market for the tied product--services of anesthesiologists.

In rejecting the application of a per se rule that all tying arrangements constitute antitrust violations, we explained:

"[W]e have condemned tying arrangements when the seller has some special ability--usually called 'market power'--to force a purchaser to do something that he would not do in a competitive market....

Per se condemnation--condemnation without inquiry into actual market conditions--is only appropriate if the existence of forcing is probable. Thus, application of the per se rule focuses on the probability of anticompetitive consequences....

For example, if the Government has granted the seller a patent or similar monopoly over a product, it is fair to presume that the inability to buy the product elsewhere gives the seller market power." United States v. Loew's Inc., 371 U.S., at 45-47. Any effort to enlarge the scope of the patent monopoly by using the market power it confers to restrain competition in the market for a second product will undermine competition on the merits in that second market. Thus, the sale or lease of a patented item on condition that the buyer make all his purchases of a separate tied product from the patentee is unlawful."

Notably, nothing in our opinion suggested a rebuttable presumption of market power applicable to tying arrangements involving a patent on the tying good. Instead, it described the rule that a contract to sell a patented product on condition that the purchaser buy unpatented goods exclusively from the patentee is a per se violation of $\S 1$ of the Sherman Act.

Justice O'Connor wrote separately in Jefferson Parish, concurring in the judgment on the ground that the case did not involve a true tying arrangement because, in her view, surgical services and anesthesia were not separate products. 466 U.S., at 43. In her opinion, she questioned not only the propriety of treating any tying arrangement as a per se violation of the Sherman Act, but also the validity of the presumption that a patent always gives the patentee significant market power, observing that the presumption was actually a product of our patent misuse cases rather than our antitrust 
jurisprudence. It is that presumption, a vestige of the Court's historical distrust of tying arrangements, that we address squarely today.

Justice O'Connor was, of course, correct in her assertion that the presumption that a patent confers market power arose outside the antitrust context as part of the patent misuse doctrine. That doctrine had its origins in Motion Picture Patents Co. v. Universal Film Mfg. Co., 243 U.S. 502 (1917), which found no support in the patent laws for the proposition that a patentee may "prescribe by notice attached to a patented machine the conditions of its use and the supplies which must be used in the operation of it, under pain of infringement of the patent," Although Motion Picture Patents Co. simply narrowed the scope of possible patent infringement claims, it formed the basis for the Court's subsequent decisions creating a patent misuse defense to infringement claims when a patentee uses its patent "as the effective means of restraining competition with its sale of an unpatented article." Morton Salt Co. v. G.S. Suppiger Co., 314 U.S. 488, 490 (1942); see also, e.g., Carbice Corp. of America v. American Patents Development Corp., 283 U.S. 27, 31 (1931).

Without any analysis of actual market conditions, these patent misuse decisions assumed that, by tying the purchase of unpatented goods to the sale of the patented good, the patentee was "restraining competition," Morton Salt, 314 U.S., at 490, or "secur[ing] a limited monopoly of an unpatented material," Mercoid, 320 U.S., at 664; see also Carbice, 283 U.S., at 31-32. In other words, these decisions presumed "[t]he requisite economic power" over the tying product such that the patentee could "extend [its] economic control to unpatented products." Loew's, 371 U.S., at $45-46$.

The presumption that a patent confers market power migrated from patent law to antitrust law in International Salt Co. v. United States, 332 U.S. 392 (1947). In that case, we affirmed a District Court decision holding that leases of patented machines requiring the lessees to use the defendant's unpatented salt products violated $\S 1$ of the Sherman Act and $\S 3$ of the Clayton Act as a matter of law. Although the Court's opinion does not discuss market power or the patent misuse doctrine, it assumes that "[t]he volume of business affected by these contracts cannot be said to be insignificant or insubstantial and the tendency of the arrangement to accomplishment of monopoly seems obvious." 
The assumption that tying contracts "ten[d] ... to accomplishment of monopoly" can be traced to the Government's brief in International Salt, which relied heavily on our earlier patent misuse decision in Morton Salt. The Government described Morton Salt as "present[ing] a factual situation almost identical with the instant case," and it asserted that "although the Court in that case did not find it necessary to decide whether the antitrust laws were violated, its language, its reasoning, and its citations indicate that the policy underlying the decision was the same as that of the Sherman Act." Brief for United States in International Salt Co. v. United States, O.T.1947, No. 46, p. 19 (United States Brief). Building on its assertion that International Salt was logically indistinguishable from Morton Salt, the Government argued that this Court should place tying arrangements involving patented products in the category of per se violations of the Sherman Act.

Our opinion in International Salt clearly shows that we accepted the Government's invitation to import the presumption of market power in a patented product into our antitrust jurisprudence. While we cited Morton Salt only for the narrower proposition that the defendant's patents did not confer any right to restrain competition in unpatented salt or afford the defendant any immunity from the antitrust laws, International Salt, 332 U.S., at 395-396, given the fact that the defendant was selling its unpatented salt at competitive prices, the rule adopted in International Salt necessarily accepted the Government's submission that the earlier patent misuse cases supported the broader proposition "that this type of restraint is unlawful on its face under the Sherman Act," United States Brief 12.

Indeed, later in the same Term we cited International Salt for the proposition that the license of "a patented device on condition that unpatented materials be employed in conjunction with the patented device" is an example of a restraint that is "illegal per se." United States v. Columbia Steel Co., 334 U.S. 495, 522-523, and n. 22 (1948). And in subsequent cases we have repeatedly grounded the presumption of market power over a patented device in International Salt. See, e.g., Loew's, 371 U.S., at 45-46; Times-Picayune Publishing Co. v. United States, 345 U.S. 594, 608 (1953); Standard Oil Co., 337 U.S., at 304.

Although the patent misuse doctrine and our antitrust jurisprudence became intertwined in International Salt, subsequent events initiated their untwining. This process has ultimately led to today's reexamination of the presumption of per se illegality of a tying arrangement involving a patented 
INNOVATION AND COMPETITION POLICY

Hovenkamp
Chap. 2, Page 85

Jan, 2013

product, the first case since 1947 in which we have granted review to consider the presumption's continuing validity.

Three years before we decided International Salt, this Court had expanded the scope of the patent misuse doctrine to include not only supplies or materials used by a patented device, but also tying arrangements involving a combination patent and "unpatented material or [a] device [that] is itself an integral part of the structure embodying the patent." Mercoid, 320 U.S., at 665; see also Dawson Chemical Co. v. Rohm \& Haas Co., 448 U.S. 176, 188-198 (1980) (describing in detail Mercoid and the cases leading up to it). In reaching this conclusion, the Court explained that it could see "no difference in principle" between cases involving elements essential to the inventive character of the patent and elements peripheral to it; both, in the Court's view, were attempts to "expan[d] the patent beyond the legitimate scope of its monopoly." Mercoid, 320 U.S., at 665.

Shortly thereafter, Congress codified the patent laws for the first time. At least partly in response to our Mercoid decision, Congress included a provision in its codification that excluded some conduct, such as a tying arrangement involving the sale of a patented product tied to an "essential" or "nonstaple" product that has no use except as part of the patented product or method, from the scope of the patent misuse doctrine. $\S 271(\mathrm{~d})$; see also Dawson, 448 U.S., at 214. Thus, at the same time that our antitrust jurisprudence continued to rely on the assumption that "tying arrangements generally serve no legitimate business purpose," Fortner I, 394 U.S., at 503, Congress began chipping away at the assumption in the patent misuse context from whence it came.

It is Congress' most recent narrowing of the patent misuse defense, however, that is directly relevant to this case. Four years after our decision in Jefferson Parish repeated the patent-equals-market-power presumption, 466 U.S., at 16, Congress amended the Patent Code to eliminate that presumption in the patent misuse context, 102 Stat. 4674. The relevant provision reads:

“(d) No patent owner otherwise entitled to relief for infringement or contributory infringement of a patent shall be denied relief or deemed guilty of misuse or illegal extension of the patent right by reason of his having done one or more of the following: ... (5) conditioned the license of any rights to the patent or the sale of the patented product on the acquisition of a license to rights in another 
INNOVATION AND COMPETITION POLICY

Hovenkamp
Chap. 2, Page 86

Jan., 2013

patent or purchase of a separate product, unless, in view of the circumstances, the patent owner has market power in the relevant market for the patent or patented product on which the license or sale is conditioned." 35 U.S.C. $§ 271(\mathrm{~d})(5)$ (emphasis added)

The italicized clause makes it clear that Congress did not intend the mere existence of a patent to constitute the requisite "market power." Indeed, fairly read, it provides that without proof that Trident had market power in the relevant market, its conduct at issue in this case was neither "misuse" nor an "illegal extension of the patent right."

While the 1988 amendment does not expressly refer to the antitrust laws, it certainly invites a reappraisal of the per se rule announced in International Salt. A rule denying a patentee the right to enjoin an infringer is significantly less severe than a rule that makes the conduct at issue a federal crime punishable by up to 10 years in prison. See 15 U.S.C. $\S 1$. It would be absurd to assume that Congress intended to provide that the use of a patent that merited punishment as a felony would not constitute "misuse." Moreover, given the fact that the patent misuse doctrine provided the basis for the market power presumption, it would be anomalous to preserve the presumption in antitrust after Congress has eliminated its foundation. Cf. 10 P. Areeda, H. Hovenkamp, \& E. Elhauge, Antitrust Law 9[1737c (2d ed.2004) (hereinafter Areeda).

After considering the congressional judgment reflected in the 1988 amendment, we conclude that tying arrangements involving patented products should be evaluated under the standards applied in cases like Fortner II and Jefferson Parish rather than under the per se rule applied in Morton Salt and Loew's. While some such arrangements are still unlawful, such as those that are the product of a true monopoly or a market wide conspiracy, see, e.g., United States v. Paramount Pictures, Inc., 334 U.S. $131,145-146$ (1948), that conclusion must be supported by proof of power in the relevant market rather than by a mere presumption thereof.

Rather than arguing that we should retain the rule of per se illegality, respondent contends that we should endorse a rebuttable presumption that patentees possess market power when they condition the purchase of the patented product on an agreement to buy unpatented goods exclusively from the patentee. Respondent recognizes that a large number of valid patents have little, if any, commercial significance, but submits that those that are used to impose tying arrangements on unwilling purchasers likely 
do exert significant market power. Hence, in respondent's view, the presumption would have no impact on patents of only slight value and would be justified, subject to being rebutted by evidence offered by the patentee, in cases in which the patent has sufficient value to enable the patentee to insist on acceptance of the tie.

Respondent also offers a narrower alternative, suggesting that we differentiate between tying arrangements involving the simultaneous purchase of two products that are arguably two components of a single product--such as the provision of surgical services and anesthesiology in the same operation, Jefferson Parish, 466 U.S., at 43 (O'Connor, J., concurring in judgment), or the licensing of one copyrighted film on condition that the licensee take a package of several films in the same transaction, Loew's, 371 U.S. 38--and a tying arrangement involving the purchase of unpatented goods over a period of time, a so-called "requirements tie." According to respondent, we should recognize a presumption of market power when faced with the latter type of arrangements because they provide a means for charging large volume purchasers a higher royalty for use of the patent than small purchasers must pay, a form of discrimination that "is strong evidence of market power." Brief for Respondent 27; see generally Jefferson Parish, 466 U.S., at 15, n. 23 (discussing price discrimination of this sort and citing sources).

The opinion that imported the "patent equals market power" presumption into our antitrust jurisprudence, however, provides no support for respondent's proposed alternative. In International Salt, it was the existence of the patent on the tying product, rather than the use of a requirements tie, that led the Court to presume market power. 332 U.S., at 395 ("The appellant's patents confer a limited monopoly of the invention they reward"). Moreover, the requirements tie in that case did not involve any price discrimination between large volume and small volume purchasers or evidence of noncompetitive pricing. Instead, the leases at issue provided that if any competitor offered salt, the tied product, at a lower price, "the lessee should be free to buy in the open market, unless appellant would furnish the salt at an equal price."

As we have already noted, the vast majority of academic literature recognizes that a patent does not necessarily confer market power. Similarly, while price discrimination may provide evidence of market power, particularly if buttressed by evidence that the patentee has charged an above-market price for the tied package, it is generally recognized that it 
INNOVATION AND COMPETITION POLICY

Hovenkamp
Chap. 2, Page 88

Jan., 2013

also occurs in fully competitive markets, see, e.g., Baumol \& Swanson, The New Economy and Ubiquitous Competitive Price Discrimination: Identifying Defensible Criteria of Market Power, 70 ANTITRUst L.J. 661, 666 (2003); 9 Areeda II 1711; Landes \& Posner 374-375. We are not persuaded that the combination of these two factors should give rise to a presumption of market power when neither is sufficient to do so standing alone. Rather, the lesson to be learned from International Salt and the academic commentary is the same: Many tying arrangements, even those involving patents and requirements ties, are fully consistent with a free, competitive market. For this reason, we reject both respondent's proposed rebuttable presumption and their narrower alternative.

It is no doubt the virtual consensus among economists that has persuaded the enforcement agencies to reject the position that the Government took when it supported the per se rule that the Court adopted in the 1940's. In antitrust guidelines issued jointly by the Department of Justice and the Federal Trade Commission in 1995, the enforcement agencies stated that in the exercise of their prosecutorial discretion they "will not presume that a patent, copyright, or trade secret necessarily confers market power upon its owner." U.S. Dept. of Justice and FTC, Antitrust Guidelines for the Licensing of Intellectual Property $\S 2.2$ (Apr. 6, 1995), available at http://www.usdoj.gov/atr/public/guidelines/. While that choice is not binding on the Court, it would be unusual for the Judiciary to replace the normal rule of lenity that is applied in criminal cases with a rule of severity for a special category of antitrust cases.

Congress, the antitrust enforcement agencies, and most economists have all reached the conclusion that a patent does not necessarily confer market power upon the patentee. Today, we reach the same conclusion, and therefore hold that, in all cases involving a tying arrangement, the plaintiff must prove that the defendant has market power in the tying product.

\section{NOTES AND QUESTIONS}

1. In the Illinois Tool Works opinion, Justice Stevens notes that there is a "virtual consensus" among economists that a patent should not be assumed to confer market power. This view is not unanimous, however. Professor Katz argues that the price a rights-holder charges for intellectual propertyincluding patents - is nearly always significantly higher than the marginal cost. This means that, under a traditional definition of market power, because the owner of the intellectual property has the ability to charge a 
price substantially higher than marginal cost, the rights-holder will almost always have market power. See Ariel Katz, Making Sense of Nonsense: Intellectual Property, Antitrust, and Market Power, 49 ARIZ. L. REV. 837 (2007) (arguing that "the relationship between [intellectual property] and market power are more than coincident. Market Power is the intended result of [intellectual property]").

2. In Chicken Delight, supra, the defendant, a struggling relatively small franchisor, argued that the plaintiffs could not establish market power because the fast-food industry was "vigorously" competitive. The Ninth Circuit acknowledged that hungry consumers had "many chicken franchising systems" to choose from. See 448 F.2d at 49. But taking a page or two from the Supreme Court's decisions in Loew's and Paramount Pictures, the Ninth Circuit presumed market power because Chicken Delight's tying product - its "name, symbols, and system of operation"was trademarked. $I d$. at 50 ("[W] e see no reason why the presumption [of market power] that exists in patent and copyright does not apply equally to [Chicken Delight's] trade-mark."). Query: virtually every business that deals in a manufactured product or has a business name also has one or more trademarks. Does that mean that all of them are monopolists?

Following Illinois Tool, the lower courts wasted little time applying the new rule to trademarks. See, e.g., Sheridan v. Marathon Petroleum Co., 530 F.3d 590 (7th Cir. 2008). In Sheridan the plaintiffs ran Marathon gas dealerships. The franchise agreements required the dealers to process all sales made with Marathon's proprietary credit card through a special system the company set up. Dealers were free to process non-Marathon credit card sales through any system they liked - but they had a "powerful incentive to route all [their] credit card transactions through the Marathon system, as otherwise [they] would have to duplicate the processing equipment that Marathon supplies." Sheridan, 530 F.3d at 596. The dealers argued that the agreements violated the Sherman Act because they tied credit-card processing to its trademark.

The trial court dismissed the complaint and the Seventh Circuit affirmed. In his opinion for the Seventh Circuit, Judge Posner eventually explained that there was no tie, Sheridan, 530 F.3d at 596 ("To call this tying would be like saying that a manufacturer of automobiles who sells tires with his cars is engaged in tying because, although the buyer is free to buy tires from someone else, he is unlikely to do so, having paid for the tires supplied by the car's manufacturer."), but first he gave the parties a 
grand tour of the market-power requirement:

The Court has not discarded the tying rule, and we have no authority to do so. But it has modified the rule by requiring proof that the seller has "market power" in the market for the tying product. ...

So "market power" is key, but its meaning requires elucidation. Monopoly power we know is a seller's ability to charge a price above the competitive level (roughly speaking, above cost, including the cost of capital) without losing so many sales to existing competitors or new entrants as to make the price increase unprofitable. The word "monopoly" in the expression "monopoly power" was never understood literally, to mean a market with only one seller; a seller who has a large market share may be able to charge a price persistently above the competitive level despite the existence of competitors. Although the price increase will reduce the seller's output (because quantity demanded falls as price rises), his competitors, if they are small, may not be able to take up enough of the slack by expanding their own output to bring price back down to the competitive level; their costs of doing so would be too high-that is doubtless why they are small.

As one moves from a market of one very large seller plus a fringe of small firms to a market of several large firms, monopoly power wanes. Now if one firm tries to charge a price above the competitive level, its competitors may have the productive capacity to be able to replace its reduction in output with an increase in their own output at no higher cost, and price will fall back to the competitive level. Eventually a point is reached at which there is no threat to competition unless sellers are able to agree, tacitly or explicitly, to limit output in order to drive price above the competitive level. The mere possibility of collusion cannot establish monopoly power, even in an attenuated sense to which the term "market power" might attach, because then every firm, no matter how small, would be deemed to have it, since successful collusion is always a possibility. 
The plaintiffs in drafting their complaint were at least dimly aware that they would have to plead and prove that Marathon had significant unilateral power over the market price of gasoline and so could charge a supracompetitive price (folded into the price for gasoline that it charges its dealers) for credit card processing. But all that the complaint states on this score is that Marathon is "the fourth-largest United States-based integrated oil and gas company and the fifth-largest petroleum refiner in the United States" and sells "petroleum products to approximately 5,600 Marathon and Speedway branded direct-served retail outlets and approximately 3,700 jobber-served retail outlets." Marathon and Speedway's alleged annual sales of six billion gallons of gasoline (improperly swollen by inclusion of Speedway's sales) are only 4.3 percent of total U.S. gasoline sales per year .... That is no one's idea of market power.

Marathon does of course have a "monopoly" of Marathon franchises. But "Marathon" is not a market; it is a trademark; and a trademark does not confer a monopoly; all it does is prevent a competitor from attaching the same name to his product. "Not even the most zealous antitrust hawk has ever argued that Amoco gasoline, Mobil gasoline, and Shell gasoline" - or, we interject, Marathon gasoline - "are three [with Marathon, four] separate product markets." Generac Corp. v. Caterpillar, Inc., 172 F.3d 971, 977 (7th Cir.1999). The complaint does not allege that there are any local gasoline markets in which Marathon has monopoly (or market) power. No market share statistics for Marathon either locally or nationally are given, and there is no information in the complaint that would enable local shares to be calculated.

What is true is that a firm selling under conditions of "monopolistic competition"- the situation in which minor product differences (or the kind of locational advantage that a local store, such as a barber shop, might enjoy in competing for some customers) limit the substitutability of otherwise very similar products - will want to trademark its brand in order to distinguish it from its competitors' brands. But the exploitation of the slight monopoly power thereby 
enabled does not do enough harm to the economy to warrant trundling out the heavy artillery of federal antitrust law. And anyway in this case monopolistic competition is not alleged either. So we are given no reason to doubt that if Marathon raises the price of using the Marathon name above the competitive level by raising the price of the credit card processing service that it offers, competing oil companies will nullify its price increase simply by keeping their own wholesale gasoline prices at the existing level. . . . [T]he plaintiffs' naked assertion of Marathon's “appreciable economic power"-an empty phrase—cannot save the complaint.

530 F.3d 592-95 (citations omitted).

\section{BRANTLEY V. NBC UNIVERSAL, INC. 675 F.3d $1192\left(9^{\text {th }}\right.$ Cir. 2012), cert. denied, S.Ct. (Nov. 5, 2012)}

\section{IKUTA, Circuit Judge:}

Plaintiffs allege that Programmers' practice of selling multi-channel cable packages violates Section 1 of the Sherman Act, 15 U.S.C. $\S 1$. In essence, plaintiffs seek to compel programmers and distributors of television programming to sell each cable channel separately, thereby permitting plaintiffs to purchase only those channels that they wish to purchase, rather than paying for multi-channel packages, as occurs under current market practice. Plaintiffs appeal the dismissal with prejudice of their complaint for failure to state a claim. We affirm.

The television programming industry can be divided into upstream and downstream markets. In the upstream market, programmers such as NBC Universal and Fox Entertainment Group own television programs (such as "Law and Order") and television channels (such as NBC's Bravo and MSNBC, and Fox Entertainment Group's Fox News Channel and FX) and sell them wholesale to distributors. In the downstream retail market, distributors such as Time Warner and Echostar sell the programming channels to consumers.

According to plaintiffs' third amended complaint, Programmers have two categories of programming channels: "must-have" channels with high 
demand and a large number of viewers, and a group of less desirable, lowdemand channels with low viewership. Plaintiffs allege that "[e]ach programmer defendant, because of its full or partial ownership of a broadcast channel and its ownership or control of multiple important cable channels, has a high degree of market power vis-a-vis all distributors," and that Programmers exploit this market power by requiring distributors, "as a condition to purchasing each programmer's broadcast channel and its "must have' cable channels," to "also acquire and resell to consumers all the rest of the cable channels owned or controlled by each programmer" and "agree they will not offer unbundled [i.e., individual] cable channels to consumers." "As a consequence," plaintiffs contend, "distributors can offer consumers only prepackaged tiers of cable channels which consist of each programmer's entire offering of channels."...

The district court dismissed plaintiffs' first amended complaint without prejudice on the ground that plaintiffs failed to show that their alleged injuries were caused by an injury to competition. In their second amended complaint, plaintiffs alleged that Programmers' practice of selling packaged cable channels foreclosed independent programmers from entering and competing in the upstream market for programming channels. The district court subsequently denied defendants' motion to dismiss, holding that plaintiffs had adequately pleaded injury to competition.

After preliminary discovery efforts on the question whether the Programmers' practices had excluded independent programmers from the upstream market, the plaintiffs decided to abandon this approach. ${ }^{12}$ Pursuant to a stipulation among the parties, plaintiffs filed their third amended complaint, which deleted all allegations that the Programmers and Distributors' contractual practices foreclosed independent programmers from participating in the upstream market, along with a motion requesting the court to rule that plaintiffs did not have to allege foreclosure in the upstream market in order to defeat a motion to dismiss.... The district court entered an order on October 15, 2009 granting Programmers and Distributors' motion to dismiss the third amended complaint with prejudice because plaintiffs failed to allege any cognizable injury to competition. The district court also denied plaintiffs' motion to rule on the question whether allegations of foreclosed competition are required to state a Section 1 claim. Plaintiffs timely appeal....

\footnotetext{
${ }^{12}$ Programmers and Distributors claim that plaintiffs decided to discontinue discovery after preliminary review showed there was no evidence to support their claim that the packaging of channels foreclosed competition in the upstream market.
} 
INNOVATION AND COMPETITION POLICY

Hovenkamp
Chap. 2, Page 94

Jan., 2013

The parties do not dispute that the rule of reason applies in this case, and the pleading requirements for a rule of reason case therefore apply. ${ }^{13}$

... In order to plead injury to competition ... sufficiently to withstand a motion to dismiss, "a section one claimant may not merely recite the bare legal conclusion that competition has been restrained unreasonably." Les Shockley Racing, Inc. v. Nat'l Hot Rod Ass'n, 884 F.2d 504, 507-08 (9th Cir.1989). "Rather, a claimant must, at a minimum, sketch the outline of [the injury to competition] with allegations of supporting factual detail." Such allegations must "raise a reasonable expectation that discovery will reveal evidence of" an injury to competition. Bell Atl. Corp. v. Twombly, 550 U.S. 544, 556, 127 S.Ct. 1955, 167 L.Ed.2d 929 (2007)....

Courts have also concluded that agreements between firms operating at different levels of a given product market (referred to as "vertical agreements"), such as agreements between a supplier and a distributor, may or may not cause an injury to competition. Vertical agreements that foreclose competitors from entering or competing in a market can injure competition by reducing the competitive threat those competitors would pose. Some types of vertical agreements can also injure competition by facilitating horizontal collusion. ...

The complaint in this case focuses on a type of vertical agreement that creates a restraint known as "tying." Tying is defined as an arrangement where a supplier agrees to sell a buyer a product (the tying product), but "only on the condition that the buyer also purchases a different (or tied) product...." N. Pac. Ry. Co. v. United States, 356 U.S. 1, 5, 78 S.Ct. 514, 2 L.Ed.2d 545 (1958). The potential injury to competition threatened by this practice is that the tying arrangement will either "harm existing competitors or create barriers to entry of new competitors in the market for the tied product," Jefferson Parish Hosp. Dist. No. 2 v. Hyde, 466 U.S. 2, 14 (1984),

\footnotetext{
${ }^{13}$ In the case of "tying" claims, a per se rule is applied in some circumstances. A tying arrangement will constitute a per se violation of the Sherman Act if the plaintiff proves "(1) that the defendant tied together the sale of two distinct products or services; (2) that the defendant possesses enough economic power in the tying product market to coerce its customers into purchasing the tied product; and (3) that the tying arrangement affects a not insubstantial volume of commerce in the tied product market." Cascade Health Solutions v. PeaceHealth, 515 F.3d 883, 913 (9th Cir.2008) (quoting Paladin Assocs., Inc. v. Mont. Power Co., 328 F.3d 1145, 1159 (9th Cir.2003)) (internal quotation marks omitted). The parties have disclaimed any contention that the tying practices in this case are per se antitrust violations.
} 
INNOVATION AND COMPETITION POLICY

Hovenkamp
Chap. 2, Page 95

Jan, 2013

abrogated in part on other grounds by Ill. Tool Works Inc. v. Indep. Ink, Inc., 547 U.S. 28 (2006); Cascade, 515 F.3d at 912, or will "force buyers into giving up the purchase of substitutes for the tied product," United States v. Loew's, 371 U.S. 38, 45 (1962), abrogated in part on other grounds by Ill. Tool Works, 547 U.S. 28.

But courts distinguish between tying arrangements in which a company exploits its market power by attempting "to impose restraints on competition in the market for a tied product" (which may threaten an injury to competition) and arrangements that let a company exploit its market power "by merely enhancing the price of the tying product" (which does not). Jefferson Parish, 466 U.S. at $14 \ldots$.

.... As the Supreme Court has noted, "when a purchaser is 'forced' to buy a product he would not have otherwise bought even from another seller in the tied product market, there can be no adverse impact on competition because no portion of the market which would otherwise have been available to other sellers has been foreclosed." Jefferson Parish, 466 U.S. at $16 \ldots .$.

Therefore, a plaintiff bringing a rule of reason tying case cannot succeed ... merely by alleging the existence of a tying arrangement, because such an arrangement is consistent with pro-competitive behavior....

There is no dispute that the complaint alleges the existence of a tying arrangement. In fact, according to the plaintiffs' complaint, the Programmer-Distributor agreements at issue consist of two separate tying arrangements. First, in the upstream market, each Programmer requires each Distributor that wishes to purchase that Programmer's high-demand channels (the tying product) to purchase all of that Programmer's lowdemand channels (the tied product) as well. ${ }^{14}$ Second, in the downstream market, Distributors sell consumers cable channels only in packages consisting of each Programmer's entire offering of channels. Thus, consumers, like Distributors, are allegedly required to purchase each Programmer's low-demand channels, which they do not want (the tied product), in order to gain access to that Programmer's high-demand channels, which they do want (the tying product).

\footnotetext{
${ }^{14}$ We assume for purposes of this opinion, without deciding, that high-demand and low-demand channels are actually separate products, and do not address the question whether it is more apt to view each Programmer's block of channels as a single product, which would preclude any argument that there was an illegal tying arrangement.
} 
INNOVATION AND COMPETITION POLICY

Hovenkamp
Chap. 2, Page 96

Jan., 2013

But as explained above, tying arrangements, without more, do not necessarily threaten an injury to competition. Therefore, the complaint's allegations regarding the two separate tying arrangements do not, by themselves, constitute a sufficient allegation of injury to competition. Rather, plaintiffs must also allege facts showing that an injury to competition flows from these tying arrangements. We conclude that such allegations are not present in the complaint.

First, it is clear that the complaint does not allege the types of injuries to competition that are typically alleged to flow from tying arrangements. The complaint does not allege that Programmers' practice of selling "must-have" and low-demand channels in packages excludes other sellers of low-demand channels from the market, or that this practice raises barriers to entry into the programming market. ${ }^{15}$ Nor do the plaintiffs allege that the tying arrangement here causes consumers to forego the purchase of substitutes for the tied product. Loew's, 371 U.S. at 45. Nothing in the complaint indicates that the arrangement between the Programmers and Distributors forces Distributors or consumers to forego the purchase of alternative low-demand channels. Indeed, Plaintiffs disavow any intent to allege that the practices engaged in by Programmers and Distributors foreclosed rivals from entering or participating in the upstream or downstream markets. Cf. Jefferson Parish, 466 U.S. at 14; Cascade, 515 F.3d at 912 ("Tying arrangements are forbidden on the theory that, if the seller has market power over the tying product, the seller can leverage this market power through tying arrangements to exclude other sellers of the tied product."). Nor does the complaint allege that the tying arrangements pose a threat to competition because they facilitate horizontal collusion.

Instead of identifying such standard-issue threats to competition, the complaint alleges that the injury to competition stems from Programmers' requirement that channels must be sold to consumers in packages. According to the complaint, the required sale of multi-channel packages harms consumers by (1) limiting the manner in which Distributors compete with one another in that Distributors are unable to offer a la carte programming, which results in (2) reducing consumer choice, and (3) increasing prices. These assertions do not sufficiently allege an injury to competition for purposes of stating a Section 1 claim. First, because Section 1 does not proscribe all contracts that limit the freedom of the contracting parties, a statement that parties have entered into a contract that limits some

\footnotetext{
${ }^{15}$ Thus, there is effectively "zero foreclosure" of competitors.
} 
freedom of action (in this case, by circumscribing the distributors' ability to offer smaller packages or channels on an unbundled basis) is not sufficient to allege an injury to competition. ${ }^{16}$

Second, allegations that an agreement has the effect of reducing consumers' choices or increasing prices to consumers does not sufficiently allege an injury to competition. Both effects are fully consistent with a free, competitive market....

Plaintiffs disagree, and argue that under the rule in Loew's, 371 U.S. 38, and Ross v. Bank of America, N.A. (USA), 524 F.3d 217 (2d Cir.2008), they have sufficiently alleged an injury to competition by alleging that the agreements have the effect of reducing choice and increasing prices. This argument is unavailing. In Loew's, the United States brought antitrust actions against six major film distributors, alleging that the defendants had conditioned the license or sale of one or more feature films upon the acceptance by television stations of a package or block containing one or more unwanted or inferior films. The Court observed that the restraint injured competition because the movie studios' block booking forced the television stations to forego purchases of movies from other distributors. The relevant injury in Loew's was to competition, not to the ultimate consumers, because the challenged practice forced television stations to forego the purchase of other movies, and therefore created barriers to entry for competing movie owners. Cf. Jefferson Parish, 466 U.S. at 14. Here, Plaintiffs have not alleged that the contracts between Programmers and Distributors forced either Distributors or consumers to forego the purchase of other low-demand channels (a result analogous to the competitive injury in Loew's ), but only that consumers could not purchase programs a la carte and they did not want all of the channels they were required to buy from Distributors. "[C]ompelling the purchase of unwanted products" is not itself an injury to competition. We have explained why this is so:

In order to obtain desired product $A$, let us suppose, the defendant's customer is forced to take product $\mathrm{B}$, which it does not want, cannot use, and would not have purchased from anyone. This is typically the equivalent of a higher price for product A. From the

\footnotetext{
${ }^{16}$ A rule to the contrary could cast doubt on whether musicians would be free to sell their hit singles only as a part of a full album, or writers to sell a collection of short stories. Indeed, such a rule would call into question whether Programmers and Distributors could sell cable channels at all, since such channels are themselves packages of separate television programs.
} 
INNOVATION AND COMPETITION POLICY

Hovenkamp
Chap. 2, Page 98

Jan., 2013

viewpoint of the defendant seller, its revenue on product $A$ consists of the A price plus the excess of the B price over B's cost to the seller. From the viewpoint of the customer, the cost of obtaining the desired product $\mathrm{A}$ is the nominal $\mathrm{A}$ price plus the excess of the $\mathrm{B}$ price over its salvage value. This has nothing to do with gaining power in the B market or upsetting competition there.

Blough, 574 F.3d at 1089-90 (quoting IX Phillip E. Areeda \& Herbert Hovenkamp, Antitrust Law II 1724b, at 270 (2004 \& Supp. 2009)); see also Jefferson Parish, 466 U.S. at 14 ("When the seller's power is just used to maximize its return in the tying product market, where presumably its product enjoys some justifiable advantage over its competitors, the competitive ideal of the Sherman Act is not necessarily compromised."). Nor does plaintiffs' citation to Ross support their argument; that case involved allegations of horizontal collusion, which has not been alleged by plaintiffs in this case, and pertained to standing, not injury to competition.

Plaintiffs also contend that because most or all Programmers and Distributors engage in the challenged practice, we should hold that in the aggregate, the practice constitutes an injury to competition. We cannot rule out the possibility that competition could be injured or reduced due to a widely applied practice that harms consumers. See Leegin, 551 U.S. at 897 (indicating that vertical restraints, such as resale price maintenance, "should be subject to more careful scrutiny" if the practice is adopted by many competitors). But the plaintiffs here have not alleged in their complaint how competition (rather than consumers) is injured by the widespread practice of packaging low- and high-demand channels. The complaint did not allege that Programmers' sale of cable channels in packages has any effect on other programmers' efforts to produce competitive programming channels or on Distributors' competition as to cost and quality of service. Nor is there any allegation that any programmer's decision to offer its channels only in packages constrained other programmers from offering their channels individually if that practice was competitively advantageous. In sum, the complaint does not include any allegation of injury to competition, as opposed to injuries to the plaintiffs.

Injury to competition must be alleged to state a violation of Sherman Act $\S 1$. Kendall, 518 F.3d at 1047. Plaintiffs' complaint does not allege facts that "raise a reasonable expectation that discovery will reveal evidence of" injury to competition. Twombly, 550 U.S. at 566. Thus, plaintiffs' complaint did not allege facts that, taken as true, "state a claim to relief that 
INNOVATION AND COMPETITION POLICY

Hovenkamp
Chap. 2, Page 99

Jan, 2013

is plausible on its face.” Id. at 570. Dismissal was proper.

\section{AFFIRMED}

\section{NOTES AND QUESTIONS}

1. The monopoly "leverage theory" is the theory that a monopolist in one market can leverage its monopoly market to reap an advantage in a separate market. Courts have begun to reject this theory, reasoning that a monopolist "can take its monopoly profits just once." Schor v. Abbott Labs., 457 F.3d 608, 611 (7th Cir. 2006), cert. denied, 549 U.S. 1205 (2007). Suppose a firm with monopoly power in one market is able to tie its monopoly product with a non-monopoly product.

For example, suppose that a firm has a patent-granted monopoly in Widgets, and the profit-maximizing price is $\$ 10$ per Widget. Suppose further that Widgets are used in conjunction with Flidgets, a non-patented product in a competitive market. If the firm tries to increase the price of Flidgets, the effect is the same as charging more for Widgets - which would decrease the firm's monopoly profits, as the profit-maximizing strategy in the patented product is to charge the monopoly price. The effect of increasing the price would be to raise prices and reduce output - something the antitrust laws are designed to protect. However, since this strategy would actually reduce the firm's profits, its profit-maximizing strategy would actually be to keep the price of Flidgets as low as possible, allowing more consumers to have access to Widgets. The more consumers who purchase Widgets at the monopoly price, the higher Firm A's monopoly profits will be.

2. Why would a cable television firm bundle stations rather than selling them ala carte? One possibility is that it is engaged in a type of price discrimination in which it takes advantage of the fact that different customers have different preferences for channels. See the notes following the Loew's decision, supra.

A more likely possibility is that the transaction costs of block pricing are much lower than the transaction costs of ala carte pricing. One television programming is produced and assembled onto a particular station the cost of transmitting that station to a view who is already wired up with cable is fairly close to zero. As a result in may cost very little more in real resources to transmit a large offering of cable channels than a smaller one. 
INNOVATION AND COMPETITION POLICY

Hovenkamp
Chap. 2, Page 100

Jan., 2013

However, ala carte pricing would require dividing up offerings according to individual consumers' tastes and putting a price on each channel. Further, the cost of the system for delivery (cable, maintenance, set-top box, and the like) is the same whether the customers buys five channels or 200.

3. Why did the plaintiffs plead their tying case only under the rule of reason? Foreclosure of competitors is not an articulated requirement of the per se tying rule? Does the Ninth Circuit's decision effectively require foreclosure in all tying cases, even those brought under the per se rule?

4. With Brantley, compare In re Cox Enterprises, Inc. Set-Top Cable Television Box Antitrust Litigation, No. 09-ML-2048-C, 2011 WL 6826813 (W.D. Okla. Dec. 28, 2011). Cox was accused of permitting certain interactive features of its cable television subscriptions to be used only with its own set top boxes. If a customer wanted to use a third party box, such as TiVo, the interactive features would not work. While set-top boxes are no longer necessary for receiving content on newer televisions, customers need them in order to interact with their televisions and use "pay-per-view," video on demand, and interactive programming guide features. Cox permits its subscribers to purchase third-party set-top boxes like TiVO or Moxi, but these third-party boxes cannot access the interactive features like video on demand or interactive programming guides The district court denied class certification of the user's tying claim because the plaintiffs could not demonstrate that they could prove market power and antitrust injury with common evidence. What would be the downstream market from which rivals or potential rivals were foreclosed? 